\title{
Schoolverlaters tussen onderwijs en arbeidsmarkt 1998
}

\author{
Citation for published version (APA):
}

Researchcentrum voor Onderwijs en Arbeidsmarkt, ROA. (1999). Schoolverlaters tussen onderwijs en arbeidsmarkt 1998: Statistische bijlage. Researchcentrum voor Onderwijs en Arbeidsmarkt, Faculteit der Economische Wetenschappen. ROA Reports No. 005B https://doi.org/10.26481/umarep.1999005B

\section{Document status and date:}

Published: 01/01/1999

DOI:

10.26481/umarep.1999005B

Document Version:

Publisher's PDF, also known as Version of record

\section{Please check the document version of this publication:}

- A submitted manuscript is the version of the article upon submission and before peer-review. There can be important differences between the submitted version and the official published version of record.

People interested in the research are advised to contact the author for the final version of the publication, or visit the DOI to the publisher's website.

- The final author version and the galley proof are versions of the publication after peer review.

- The final published version features the final layout of the paper including the volume, issue and page numbers.

Link to publication

\footnotetext{
General rights rights.

- You may freely distribute the URL identifying the publication in the public portal. please follow below link for the End User Agreement:

www.umlib.nl/taverne-license

Take down policy

If you believe that this document breaches copyright please contact us at:

repository@maastrichtuniversity.nl

providing details and we will investigate your claim.
}

Copyright and moral rights for the publications made accessible in the public portal are retained by the authors and/or other copyright owners and it is a condition of accessing publications that users recognise and abide by the legal requirements associated with these

- Users may download and print one copy of any publication from the public portal for the purpose of private study or research.

- You may not further distribute the material or use it for any profit-making activity or commercial gain

If the publication is distributed under the terms of Article $25 \mathrm{fa}$ of the Dutch Copyright Act, indicated by the "Taverne" license above, 


\section{Statistische Bijlage \\ Schoolverlaters tussen onderwijs en arbeidsmarkt 1998}

ROA-R-1999/5B

Researchcentrum voor Onderwijs en Arbeidsmarkt

Faculteit der Economische Wetenschappen en Bedrijfskunde Universiteit Maastricht

Maastricht, juni 1999 
Niets uit deze uitgave mag worden verveelvoudigd en/of openbaar gemaakt door middel van druk, fotokopie, microfilm, of op welke wijze ook, zonder voorafgaande schriftelijke toestemming van de directeur van het Researchcentrum voor Onderwijs en Arbeidsmarkt. In geval van overname van het datamateriaal moet telkens duidelijk als bron worden vermeld: "Researchcentrum voor Onderwijs en Arbeidsmarkt" of "ROA". Van publicaties waarin gebruik wordt gemaakt van gegevens uit deze Statistische bijlage ontvangen wij gaarne een exemplaar.

Hoewel de grootst mogelijke zorg is besteed aan de inhoud van dit rapport, kan het ROA in generlei opzicht verantwoordelijkheid op zich nemen voor eventuele onvolledigheden of onjuistheden.

ISBN 90-5321-252-3

SEC99.071/RvdV 


\section{Inhoud}

Bladzijde

Voorwoord

\section{A. Tabellen per opleidingssector}

\section{Bestemming van schoolverlaters}

A1.1 De uitstroom van schoolverlaters verbijzonderd naar geslacht, etniciteit en gemiddelde leeftijd op moment van enquête 3

A1.2 Hoogste in het voortgezet onderwijs behaalde diploma 4

$\begin{array}{lll}\text { A1.3 Bestemming van schoolverlaters } & 5\end{array}$

$\begin{array}{ll}\text { A1.4 Gevolgde opleiding opnieuw kiezen? } & 6\end{array}$

2 Doorstroom naar vervolgonderwijs

$\begin{array}{lll}\text { A2.1 } & \text { Doorstroom van schoolverlaters naar het voltijd vervolgonderwijs } & 7\end{array}$

A2.2 Belangrijkste opleidingen van schoolverlaters die een voltijd vervolgopleiding zijn gaan volgen

A2.3 Oordeel van schoolverlaters over de aansluiting van de afgesloten opleiding met de voltijd vervolgopleiding

A2.4 Doorstroom van schoolverlaters naar de beroepsbegeleidende leerweg

3 Intrede op de arbeidsmarkt

A3.1 Werkloosheid en gemiddelde intredewerkloosheid van schoolverlaters die zich aanbieden op de arbeidsmarkt

A3.2 Aard van het dienstverband van werkende schoolverlaters $\quad 18$

A3.3 Percentage werkende schoolverlaters met een flexibele aanstelling 20

A3.4 Wijze van verkrijgen van een baan $\quad 21$

A3.5 Belangrijkste bedrijfsgroepen waarin schoolverlaters werkzaam zijn 23

A3.6 Belangrijkste beroepsgroepen waarin schoolverlaters werkzaam zijn 27

A3.7 Grootte van de organisatie waarin schoolverlaters werkzaam zijn 31

A3.8 Beloning van werkende schoolverlaters

A3.9 Vereist opleidingsniveau voor de huidige functie volgens de werkgever 33

A3.10 Vereiste opleidingsrichting voor de huidige functie volgens de werkgever $\quad 34$

A3.11 Gewenste en feitelijke wekelijkse arbeidsduur van werkende schoolverlaters $\quad 35$

A3.12 Oordeel van de werkende schoolverlaters over de aansluiting tussen de afgesloten opleiding en de huidige functie $\quad 36$

A3.13 Percentage werkende schoolverlaters dat op zoek is naar een andere baan $\quad 37$

A3.14 Deelname aan een cursus of bedrijfsopleiding door werkende schoolverlaters 38

A3.15 Belangrijkste cursussen of bedrijfsopleidingen waaraan werkende schoolverlaters deelnemen 
4 Kernindicatoren

A4.1 Enkele kernindicatoren

\section{B. Tabellen per opleidingsrichting}

\section{Bestemming van schoolverlaters}

B1.1 De uitstroom van schoolverlaters verbijzonderd naar geslacht, etniciteit en gemiddelde leeftijd op moment van enquête

B1.2 Hoogste in het voortgezet onderwijs behaalde diploma 49

B1.3 Bestemming van schoolverlaters 50

B1.4 Gevolgde opleiding opnieuw kiezen?

2 Doorstroom naar vervolgonderwijs

B2.1 Doorstroom van schoolverlaters naar het voltijd vervolgonderwijs

B2.2 Belangrijkste opleidingen van schoolverlaters die een voltijd vervolgopleiding zijn gaan volgen

B2.3 Oordeel van schoolverlaters over de aansluiting van de afgesloten opleiding met de voltijd vervolgopleiding

B2.4 Doorstroom van schoolverlaters naar de beroepsbegeleidende leerweg

3 Intrede op de arbeidsmarkt

B3.1 Werkloosheid en gemiddelde intredewerkloosheid van schoolverlaters die zich aanbieden op de arbeidsmarkt

B3.2 Aard van het dienstverband van werkende schoolverlaters $\quad 67$

B3.3 Percentage werkende schoolverlaters met een flexibele aanstelling 69

$\begin{array}{lll}\text { B3.4 Wijze van verkrijgen van een baan } & 71\end{array}$

B3.5 Belangrijkste bedrijfsgroepen waarin schoolverlaters werkzaam zijn $\quad 73$

B3.6 Belangrijkste beroepsgroepen waarin schoolverlaters werkzaam zijn $\quad 81$

B3.7 Grootte van de organisatie waarin schoolverlaters werkzaam zijn

B3.8 Beloning van werkende schoolverlaters $\quad 91$

B3.9 Vereist opleidingsniveau voor de huidige functie volgens de werkgever 93

B3.10 Vereiste opleidingsrichting voor de huidige functie volgens de werkgever $\quad 95$

B3.11 Gewenste en feitelijke wekelijkse arbeidsduur van werkende schoolverlaters $\quad 97$

B3.12 Oordeel van de werkende schoolverlaters over de aansluiting tussen de afgesloten opleiding en de huidige functie 99

B3.13 Percentage werkende schoolverlaters dat op zoek is naar een andere baan $\quad 100$

B3.14 Deelname aan een cursus of bedrijfsopleiding door werkende schoolverlaters 102

B3.15 Belangrijkste cursussen of bedrijfsopleidingen waaraan werkende schoolverlaters deelnemen

4 Kernindicatoren

B4.1 Enkele kernindicatoren 


\section{Respons}

C.1 Ongewogen aantal respondenten verbijzonderd naar bestemming per opleidingssector

C.2 Naar landelijke populatie gewogen aantal schoolverlaters verbijzonderd naar bestemming per opleidingssector

C.3 Responspercentage per opleidingssector

C.4 Ongewogen aantal respondenten verbijzonderd naar bestemming per opleidingsrichting

C.5 Naar landelijke populatie gewogen aantal schoolverlaters verbijzonderd naar bestemming per opleidingsrichting

C.6 Responspercentage per opleidingsrichting

\section{Opleidingsindeling}

Overzicht van opleidingen per opleidingssector 
$\ldots$ 
Tabellenoverzicht Statistische Bijlage

Schoolverlaters tussen Onderwijs en Arbeidsmarkt

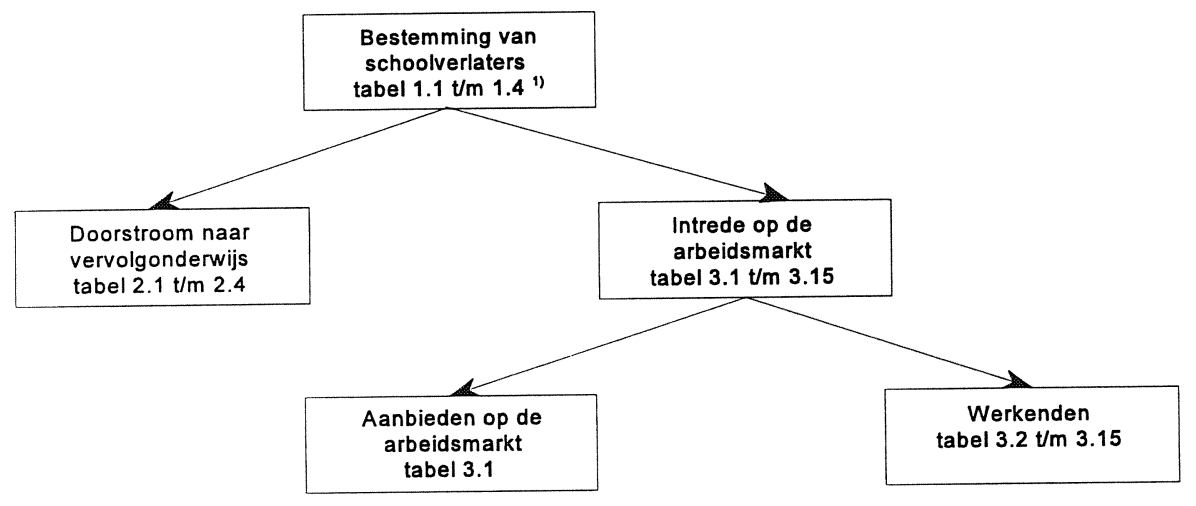

1) Tabelnummers gelden voor het A-deel en het B-deel van de statistische bijlage. Het A-deel bestaat uit tabellen naar opleidingssector, het B-deel uit tabellen naar opleidingsrichting. 


\section{Voorwoord}

In deze Statistische Bijlage bij het rapport Schoolverlaters tussen onderwijs en arbeidsmarkt 1998 wordt een overzicht gegeven van de belangrijkste resultaten van de schoolverlatersonderzoeken die door het ROA in het najaar van 1998 zijn gehouden onder schoolverlaters en afgestudeerden van het school- of studiejaar 1996/1997. Allereerst betreft dit de enquête Registratie van Uitstroom en Bestemming van Schoolverlaters (RUBS). Deze enquête is gericht op schoolverlaters van het voortgezet onderwijs (AVO en VBO) en het secundair beroepsonderwijs. Wat dit laatste betreft zijn vooralsnog alleen de gegevens voor de Beroepsopleidende leerweg $(B O L)^{1}$ beschreven. Daarnaast zijn gegevens opgenomen afkomstig uit de HBO-Monitor, een volledig vergelijkbare enquête gericht op afgestudeerden van het HBO. Ten slotte zijn data gepresenteerd van de WO-Monitor, een vergelijkbare enquête onder afgestudeerde academici die in 1998 voor het eerst integraal is gehouden.

De Statistische Bijlage bevat vier delen. In deel A worden de belangrijkste gegevens per onderwijssoort en opleidingssector (bijvoorbeeld BOL niveau 1/2 techniek, HBO economie, WO gezondheidszorg) gepresenteerd. Binnen het secundair beroepsonderwijs zijn daarbij de niveaus 1 en 2 (assistent beroepsbeoefenaar of beginnend beroepsbeoefenaar) aan de ene kant en 3 en 4 (zelfstandig beroepsbeoefenaar en middenkaderfunctionaris of specialist) aan de andere kant samengenomen. Deel $\mathrm{B}$ geeft vervolgens voor de opleidingen van $\mathrm{VBO}$ en $\mathrm{BOL}$ een gedetailleerder overzicht $^{2}$. Daarbij worden alleen voor die opleidingen resultaten gepresenteerd waarvoor de resultaten voldoende betrouwbaar worden geacht. Eenvoudigheidshalve is daartoe een grens van 15 respondenten gehanteerd. Bij tabellen die betrekking hebben op de beroepsbevolking of de werkenden is de grens gesteld op 15 respondenten die tot de beroepsbevolking behoren. Bij sommige tabellen kunnen de gepresenteerde percentages vanwege ontbrekende waarnemingen overigens op een geringer aantal waarnemingen zijn gebaseerd. Hiermee dient bij de interpretatie van de gegevens rekening te worden gehouden. Bij tabellen die betrekking hebben op de opleidingen of de cursussen die door de respondenten zijn gevolgd is de grens gelegd bij minimaal 15 respondenten die een opleiding respectievelijk cursus hebben gevolgd. In deel B zijn de opleidingen en cursussen met een te klein aantal respondenten niet in de tabellen opgenomen. Voor alle tabellen geldt dat het gaat om de gediplomeerde schoolverlaters van de voltijd opleidingen.

Binnen de delen A en B is een onderverdeling gemaakt. Het eerste onderdeel gaat in op de bestemming van schoolverlaters: werken, leren of een combinatie via de beroepsbegeleidende leerweg (BBL). Onderdeel 2 gaat dieper in op de verder lerenden, terwijl onderdeel 3 de intrede op de arbeidsmarkt nader beschrijft. Beide delen bevatten verder een samenvattende tabel 4 met enkele kernindicatoren.

Deel C geeft enkele achtergrondciffers van de enquête: ongewogen en opgehoogde aantallen,

1. Ondanks dat het merendeel van de hier onderzochte schoolverlaters formeel de opleiding nog in de oude structuur hebben gevolgd, wordt in deze Statistische Bijlage reeds uitgegaan van de naamgeving zoals die sinds de invoering van de Wet Educatie en Beroepsonderwijs (WEB) geldt.

2. Voor een gedetailleerd beeld van de resultaten voor het HBO wordt verwezen naar het gelijktijdig verschenen Statistisch supplement van de HBO-Monitor uitgegeven door de HBO-Raad. Uitvoeriger resultaten van de WO-Monitor zullen later dit jaar bekend worden gemaakt door de VSNU. 
alsmede de responspercentages. In deel D van deze Statistische Bijlage is tot slot een overzicht opgenomen van de in de enquête opgenomen opleidingen per sector. 
A. Tabellen per opleidingssector 

Tabel A1.1

De uitstroom van schoolverlaters verbijzonderd naar geslacht, etniciteit en gemiddelde leeftijd op moment van enquête

\begin{tabular}{lcl}
\hline Opleidingssector & $\substack{\% \\
\%}$ & allochtoon \\
$\%$ & gem. leeftijd
\end{tabular}

\begin{tabular}{llll}
\hline AVO & & & \\
MAVO & 53 & 5 & 17,4 \\
HAVO & 56 & 2 & 18,9 \\
VWO & 51 & 1 & 19,5 \\
Totaal & 53 & 3 & 18,4 \\
VBO & & & \\
IVBO & 51 & 7 & 17,9 \\
landbouw & 46 & 0 & 17,6 \\
techniek & 7 & 2 & 17,7 \\
economie & 64 & 7 & 17,6 \\
gezondheidszorg & 95 & 1 & 17,5 \\
Totaal & 47 & 4 & 17,7
\end{tabular}

BOL niv. $1 / 2$

oriënteren en schakelen

landbouw

techniek

economie

gezondheidszorg

Totaal

17,4

9,5

8,4

BOL niv. $3 / 4$

landbouw

techniek

economie

gezondheidszorg

gedrag en maatschappij

Totaal

17,7

17,6

17,5
17,7

HBO

landbouw

onderwijs

techniek

economie

gezondheidszorg

gedrag en maatschappij

kunst en cultuur

Totaal

$\begin{array}{rrr}56 & 12 & 19,3 \\ 43 & 0 & 20,0 \\ 8 & 12 & 20,4 \\ 54 & 17 & 20,4 \\ 91 & 11 & 20,4 \\ 51 & 13 & 20,0\end{array}$

wo

landbouw

techniek

economie

gezondheidszorg

gedrag en maatschappij

taal en cultuur

recht en openbare orde

natuurwetenschappen

Totaal

$\begin{array}{lll}31 & 0 & 21,5 \\ 12 & 3 & 22,5 \\ 52 & 5 & 21,4 \\ 88 & 3 & 21,4 \\ 89 & 5 & 22,2 \\ 54 & 4 & 21,8\end{array}$

Totaal

$\begin{array}{lll}32 & 0 & 24,8 \\ 78 & 1 & 24,7 \\ 17 & 2 & 25,1 \\ 49 & 1 & 24,8 \\ 83 & 1 & 24,9 \\ 81 & 3 & 25,1 \\ 61 & 1 & 27,1 \\ 53 & 2 & 25,1\end{array}$

Toelichting

- Een allochtoon is óf iemand die zelf en van wie ten minste één van de ouders in het buitenland is geboren of iemand van wie beide ouders in het buitenland zijn geboren. Landen die tot het buitenland worden gerekend, zijn landen die worden genoemd in de Wet Bevordering Evenredige Arbeidsdeelname Allochtonen.

- Het betreft de leeftijd per onderzoeksdatum ongeveer anderhalf jaar na schoolverlaten.

- Voor het WO zijn de resultaten met betrekking tot allochtonen gebaseerd op 9 universiteiten. 
Tabel A1.2

Hoogste in het voortgezet onderwijs behaalde diploma

\begin{tabular}{|c|c|c|c|c|c|c|c|}
\hline Opleidingssector & $\begin{array}{c}\text { MAVO } \\
\%\end{array}$ & $\begin{array}{c}\text { HAVO } \\
\%\end{array}$ & $\begin{array}{c}\text { VWO } \\
\%\end{array}$ & $\begin{array}{c}\text { VBO } \\
\%\end{array}$ & $\begin{array}{c}\text { BOL } \\
\text { niv. } 1 / 2 \\
\%\end{array}$ & $\begin{array}{c}\mathrm{BOL} \\
\text { niv. } 3 / 4 \\
\%\end{array}$ & $\begin{array}{c}\text { overig } \\
\%\end{array}$ \\
\hline $\begin{array}{l}\text { BOL niv. } 1 / 2 \\
\text { oriënteren en schakelen } \\
\text { landbouw } \\
\text { techniek } \\
\text { economie } \\
\text { gezondheidszorg } \\
\text { Totaal }\end{array}$ & $\begin{array}{l}37 \\
14 \\
24 \\
37 \\
10 \\
32\end{array}$ & $\begin{array}{l}9 \\
0 \\
0 \\
1 \\
2 \\
4\end{array}$ & $\begin{array}{l}1 \\
0 \\
0 \\
0 \\
0 \\
0\end{array}$ & $\begin{array}{l}41 \\
81 \\
67 \\
52 \\
79 \\
54\end{array}$ & $\begin{array}{l}1 \\
1 \\
7 \\
6 \\
2 \\
4\end{array}$ & $\begin{array}{l}4 \\
3 \\
0 \\
2 \\
3 \\
3\end{array}$ & $\begin{array}{l}7 \\
2 \\
1 \\
2 \\
5 \\
4\end{array}$ \\
\hline $\begin{array}{l}\text { BOL niv. } 3 / 4 \\
\text { landbouw } \\
\text { techniek } \\
\text { economie } \\
\text { gezondheidszorg } \\
\text { gedrag en maatschappij } \\
\text { Totaal }\end{array}$ & $\begin{array}{l}43 \\
57 \\
58 \\
63 \\
63 \\
58\end{array}$ & $\begin{array}{r}11 \\
12 \\
24 \\
8 \\
6 \\
15\end{array}$ & $\begin{array}{l}0 \\
1 \\
1 \\
0 \\
0 \\
1\end{array}$ & $\begin{array}{l}41 \\
24 \\
10 \\
23 \\
23 \\
20\end{array}$ & $\begin{array}{l}1 \\
1 \\
5 \\
3 \\
3 \\
3\end{array}$ & $\begin{array}{l}4 \\
4 \\
2 \\
3 \\
3 \\
3\end{array}$ & $\begin{array}{l}1 \\
1 \\
0 \\
0 \\
1 \\
1\end{array}$ \\
\hline $\begin{array}{l}\text { HBO } \\
\text { landbouw } \\
\text { onderwijs } \\
\text { techniek } \\
\text { economie } \\
\text { gezondheidszorg } \\
\text { gedrag en maatschappij } \\
\text { kunst en cultuur } \\
\text { Totaal }\end{array}$ & $\begin{array}{l}1 \\
2 \\
2 \\
1 \\
1 \\
2 \\
5 \\
2\end{array}$ & $\begin{array}{l}42 \\
67 \\
32 \\
30 \\
55 \\
50 \\
45 \\
42\end{array}$ & $\begin{array}{l}24 \\
17 \\
29 \\
43 \\
26 \\
18 \\
32 \\
30\end{array}$ & $\begin{array}{l}0 \\
0 \\
0 \\
0 \\
0 \\
0 \\
1 \\
0\end{array}$ & $\begin{array}{l}0 \\
0 \\
0 \\
0 \\
0 \\
0 \\
0 \\
0\end{array}$ & $\begin{array}{l}33 \\
14 \\
38 \\
26 \\
16 \\
29 \\
15 \\
27\end{array}$ & $\begin{array}{l}0 \\
0 \\
0 \\
0 \\
1 \\
1 \\
1 \\
0\end{array}$ \\
\hline $\begin{array}{l}\text { WO } \\
\text { landbouw } \\
\text { techniek } \\
\text { economie } \\
\text { gezondheidszorg } \\
\text { gedrag en maatschappij } \\
\text { taal en cultuur } \\
\text { recht en openbare orde } \\
\text { natuurwetenschappen } \\
\text { Totaal }\end{array}$ & $\begin{array}{l}0 \\
0 \\
0 \\
0 \\
0 \\
1 \\
0 \\
0 \\
0\end{array}$ & $\begin{array}{r}12 \\
6 \\
7 \\
7 \\
18 \\
18 \\
13 \\
4 \\
7 \\
9\end{array}$ & $\begin{array}{l}84 \\
90 \\
90 \\
92 \\
77 \\
85 \\
93 \\
90 \\
88\end{array}$ & $\begin{array}{l}0 \\
0 \\
0 \\
0 \\
0 \\
0 \\
0 \\
0 \\
0\end{array}$ & $\begin{array}{l}0 \\
0 \\
0 \\
0 \\
0 \\
0 \\
0 \\
0 \\
0\end{array}$ & $\begin{array}{l}4 \\
4 \\
3 \\
1 \\
4 \\
1 \\
2 \\
3 \\
3\end{array}$ & $\begin{array}{l}0 \\
0 \\
0 \\
0 \\
0 \\
0 \\
0 \\
0 \\
0\end{array}$ \\
\hline
\end{tabular}

Toelichting

- Voor het WO hebben de resultaten betrekking op 9 universiteiten. 
Tabel $A 1.3$

Bestemming van schoolverlaters

\begin{tabular}{|c|c|c|c|c|c|}
\hline Opleidingssector & $\begin{array}{r}\text { studie } \\
\%\end{array}$ & $\begin{array}{r}\text { BBL } \\
\%\end{array}$ & $\begin{array}{r}\text { betaald } \\
\text { werk } \\
\%\end{array}$ & $\begin{array}{r}\text { werkloos } \\
\%\end{array}$ & $\begin{array}{r}\text { anders } \\
\%\end{array}$ \\
\hline $\begin{array}{l}\text { AVO } \\
\text { MAVO } \\
\text { HAVO } \\
\text { VWO } \\
\text { Totaal }\end{array}$ & $\begin{array}{l}83 \\
89 \\
95 \\
88\end{array}$ & $\begin{array}{l}6 \\
2 \\
0 \\
3\end{array}$ & $\begin{array}{l}8 \\
8 \\
3 \\
7\end{array}$ & $\begin{array}{l}1 \\
0 \\
0 \\
0\end{array}$ & $\begin{array}{l}2 \\
2 \\
1 \\
2\end{array}$ \\
\hline $\begin{array}{l}\text { VBO } \\
\text { IVBO } \\
\text { landbouw } \\
\text { techniek } \\
\text { economie } \\
\text { gezondheidszorg } \\
\text { Totaal }\end{array}$ & $\begin{array}{l}46 \\
67 \\
44 \\
66 \\
63 \\
54\end{array}$ & $\begin{array}{r}23 \\
15 \\
27 \\
8 \\
12 \\
19\end{array}$ & $\begin{array}{l}28 \\
15 \\
27 \\
24 \\
20 \\
24\end{array}$ & $\begin{array}{l}1 \\
1 \\
1 \\
1 \\
1 \\
1\end{array}$ & $\begin{array}{l}2 \\
3 \\
1 \\
1 \\
3 \\
2\end{array}$ \\
\hline $\begin{array}{l}\text { BOL niv. } 1 / 2 \\
\text { oriënteren en schakelen } \\
\text { landbouw } \\
\text { techniek } \\
\text { economie } \\
\text { gezondheidszorg } \\
\text { Totaal }\end{array}$ & $\begin{array}{l}52 \\
27 \\
14 \\
29 \\
30 \\
36\end{array}$ & $\begin{array}{r}3 \\
15 \\
15 \\
7 \\
8 \\
7\end{array}$ & $\begin{array}{l}38 \\
52 \\
68 \\
59 \\
55 \\
52\end{array}$ & $\begin{array}{l}4 \\
5 \\
1 \\
2 \\
3 \\
3\end{array}$ & $\begin{array}{l}3 \\
1 \\
2 \\
2 \\
4 \\
3\end{array}$ \\
\hline $\begin{array}{l}\text { BOL niv. } 3 / 4 \\
\text { landbouw } \\
\text { techniek } \\
\text { economie } \\
\text { gezondheidszorg } \\
\text { gedrag en maatschappij } \\
\text { Totaal }\end{array}$ & $\begin{array}{l}21 \\
38 \\
35 \\
24 \\
36 \\
33\end{array}$ & $\begin{array}{l}2 \\
1 \\
1 \\
4 \\
2 \\
2\end{array}$ & $\begin{array}{l}75 \\
59 \\
61 \\
69 \\
57 \\
62\end{array}$ & $\begin{array}{l}1 \\
1 \\
1 \\
2 \\
2 \\
1\end{array}$ & $\begin{array}{l}2 \\
1 \\
1 \\
2 \\
3 \\
1\end{array}$ \\
\hline $\begin{array}{l}\text { HBO } \\
\text { landbouw } \\
\text { onderwijs } \\
\text { techniek } \\
\text { economie } \\
\text { gezondheidszorg } \\
\text { gedrag en maatschappij } \\
\text { kunst en cultuur } \\
\text { Totaal }\end{array}$ & $\begin{array}{r}12 \\
9 \\
12 \\
12 \\
7 \\
9 \\
9 \\
10\end{array}$ & $\begin{array}{l}x \\
x \\
x \\
x \\
x \\
x \\
x \\
x\end{array}$ & $\begin{array}{l}83 \\
86 \\
86 \\
85 \\
90 \\
84 \\
68 \\
85\end{array}$ & $\begin{array}{l}3 \\
3 \\
1 \\
2 \\
2 \\
4 \\
6 \\
2\end{array}$ & $\begin{array}{r}1 \\
2 \\
1 \\
1 \\
2 \\
3 \\
17 \\
2\end{array}$ \\
\hline $\begin{array}{l}\text { WO } \\
\text { landbouw } \\
\text { techniek } \\
\text { economie } \\
\text { gezondheidszorg } \\
\text { gedrag en maatschappij } \\
\text { taal en cultuur } \\
\text { recht en openbare orde } \\
\text { natuurwetenschappen } \\
\text { Totaal }\end{array}$ & $\begin{array}{l}2 \\
1 \\
1 \\
1 \\
3 \\
6 \\
2 \\
3 \\
2\end{array}$ & $\begin{array}{l}x \\
x \\
x \\
x \\
x \\
x \\
x \\
x \\
x\end{array}$ & $\begin{array}{l}92 \\
98 \\
98 \\
96 \\
91 \\
88 \\
95 \\
94 \\
94\end{array}$ & $\begin{array}{l}4 \\
1 \\
1 \\
2 \\
4 \\
5 \\
2 \\
3 \\
3\end{array}$ & $\begin{array}{l}2 \\
0 \\
0 \\
1 \\
3 \\
2 \\
1 \\
1 \\
1\end{array}$ \\
\hline Totaal & 52 & 5 & 39 & 1 & 2 \\
\hline
\end{tabular}

$\mathrm{x}=$ antwoordcategorie niet opgenomen 
Tabel A1.4

Gevolgde opleiding opnieuw kiezen?

\begin{tabular}{|c|c|c|c|}
\hline & $\begin{array}{l}\text { zelfde } \\
\text { opleiding }\end{array}$ & $\begin{array}{l}\text { andere } \\
\text { opleiding }\end{array}$ & $\begin{array}{c}\text { geen } \\
\text { opleiding }\end{array}$ \\
\hline \multicolumn{4}{|l|}{ BOL niv. $1 / 2$} \\
\hline oriënteren en schakelen & 53 & 32 & 15 \\
\hline landbouw & 72 & 28 & 0 \\
\hline techniek & 64 & 30 & 6 \\
\hline economie & 61 & 33 & 6 \\
\hline gezondheidszorg & 61 & 37 & 2 \\
\hline Totaal & 58 & 32 & 9 \\
\hline \multicolumn{4}{|l|}{ BOL niv. $3 / 4$} \\
\hline landbouw & 68 & 29 & 3 \\
\hline techniek & 77 & 22 & 1 \\
\hline economie & 72 & 27 & 1 \\
\hline gezondheidszorg & 70 & 29 & 1 \\
\hline gedrag en maatschappij & 79 & 21 & 0 \\
\hline Totaal & 74 & 25 & 1 \\
\hline \multicolumn{4}{|l|}{ HBO } \\
\hline landbouw & 79 & 20 & 1 \\
\hline onderwijs & 82 & 18 & 1 \\
\hline techniek & 80 & 19 & 1 \\
\hline economie & 75 & 24 & 0 \\
\hline gezondheidszorg & 81 & 19 & 0 \\
\hline gedrag en maatschappij & 75 & 24 & 0 \\
\hline kunst en cultuur & 88 & 11 & 1 \\
\hline Totaal & 79 & 20 & 1 \\
\hline \multicolumn{4}{|l|}{ wo } \\
\hline landbouw & 73 & 26 & 0 \\
\hline techniek & 85 & 15 & 0 \\
\hline economie & 88 & 11 & 0 \\
\hline gezondheidszorg & 86 & 13 & 0 \\
\hline gedrag en maatschappij & 75 & 24 & 1 \\
\hline taal en cultuur & 69 & 30 & 1 \\
\hline recht en openbare orde & 86 & 14 & 1 \\
\hline natuurwetenschappen & 79 & 20 & 1 \\
\hline Totaal & 81 & 18 & 1 \\
\hline Totaal & 74 & 24 & 2 \\
\hline
\end{tabular}

Toelichting

- Voor het WO hebben de resultaten betrekking op 9 universiteiten. 


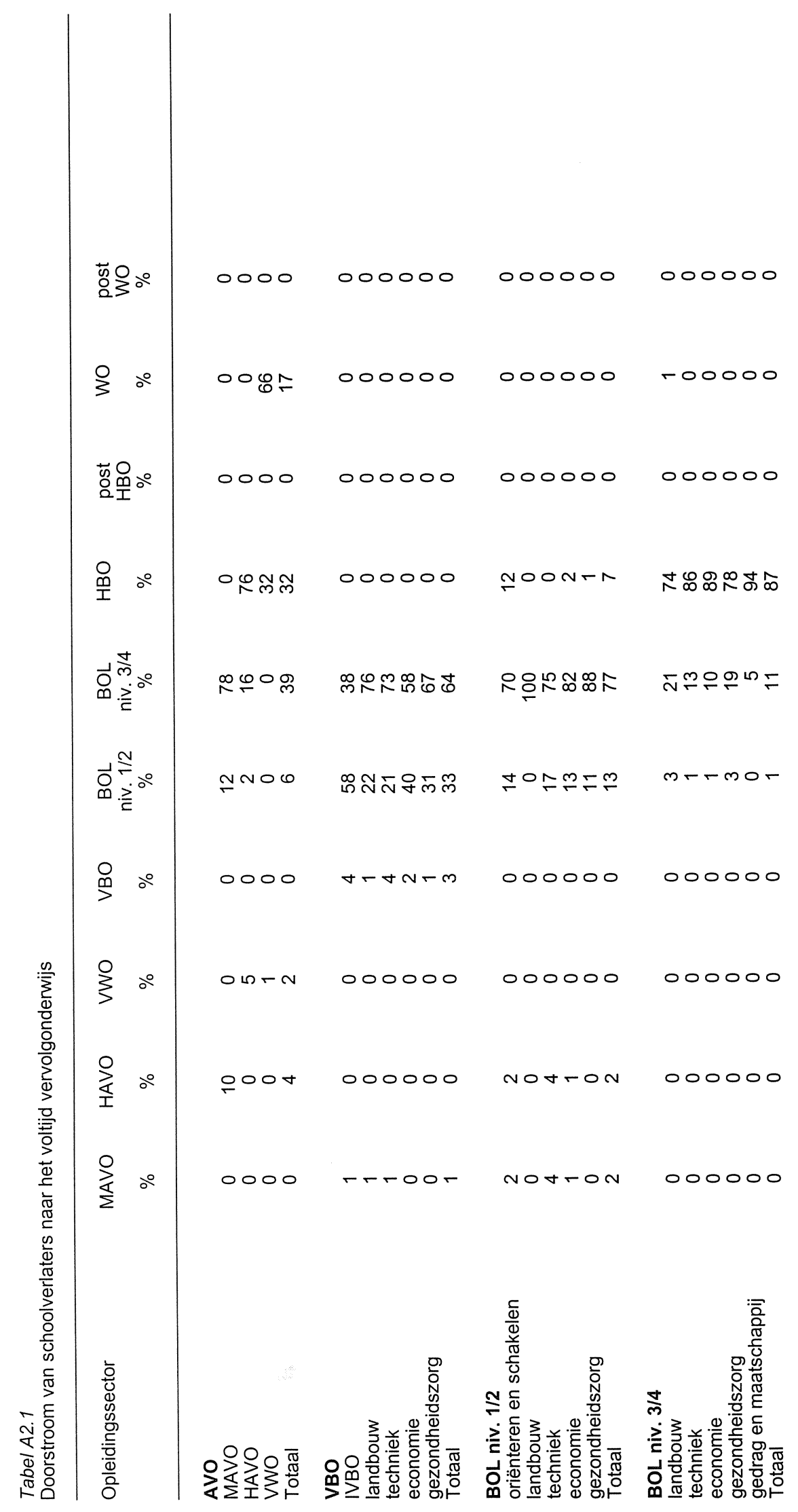




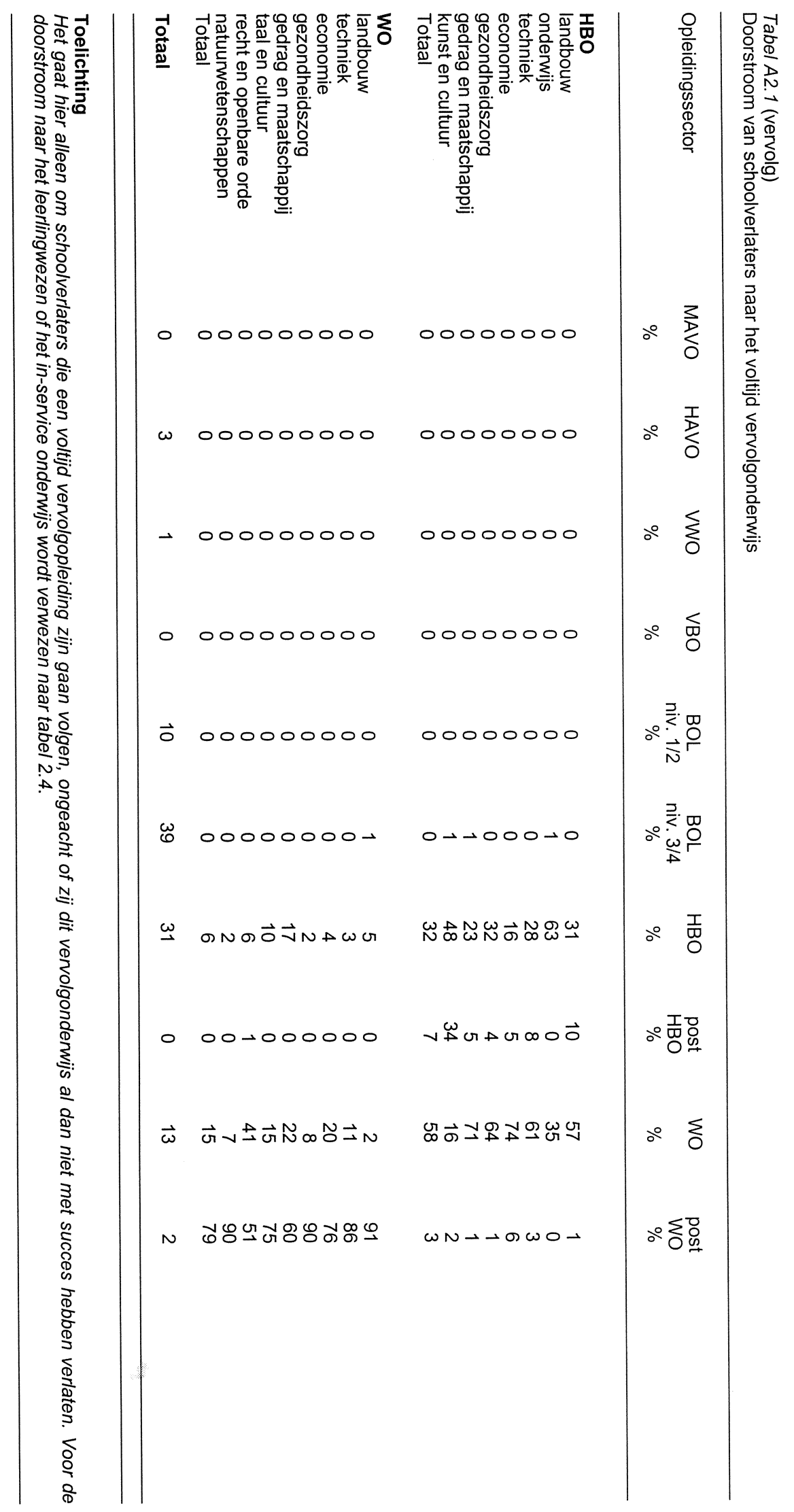


Tabel A2.2

Belangrijkste opleidingen van schoolverlaters die een voltijd vervolgopleiding zijn gaan volgen

MAVO

HAVO

BOL MKF Sociaal-pedagogisch werk

HAVO

HBO Leraar basisonderwijs

VWO

HBO Opleiding tot verpleegkundige

5

WO Nederlands recht (ook OU)

BOL BB Helpende (verpleging en verzorging)

$B O L$ MKF Verpleging en verzorging

BOL KF Veehouderij

BOL MKF Energie- en informatietechniek

VBO economie

BOL BB Bedrijfsadministratie

BOL MKF Detailhandel/ambulante handel

7

BOL AB Secretarieel

VBO gezondheidszorg

BOL MKF Sociaal-pedagogisch werk

BOL ZB Verzorgende

BOL BB Helpende (verpleging en verzorging)

24

$B O L$ niv. $1 / 2$ oriënteren en schakelen

BOL MKF Sociaal-pedagogisch werk

BOL ZB Detailhandel/ambulante handel

BOL MKF Sport en bewegen

BOL MKF Sport- en bewegingsleider

HBO Sport en bewegen

BOL niv. $1 / 2$ landbouw

BBL ZB Dierenonderneming

BOL MKF Commercieel

BOL MKF Sociaal-pedagogisch werk

BOL ZB Groene ruimte

BOL KF Bos- en natuurbeheer

BOL niv. 1/2 techniek

BOL MKF Werktuigbouwkunde

BBL ZB Energie- en informatietechniek

BOL MKF Energie- en informatietechniek

BOL niv. 1/2 economie

BOL MKF Detailhandel/ambulante handel

BBL ZB Zelfstandig werkend kok

BOL MKF Bedriifsadministratief 
Tabel A2.2 (vervolg)

Belangrijkste opleidingen van schoolverlaters die een voltijd vervolgopleiding zijn gaan volgen

BOL niv. 1/2 gezondheidszorg

BOL ZB Verzorgende

BOL MKF Sociaal-pedagogisch werk

BOL MKF Verpleging en verzorging

BOL ZB All-round kapper

BBL ZB Verzorgende bij inst. voor gezinsverz.

$\mathrm{BOL} Z \mathrm{~B}$ Verpleging en verzorging

18

11

9

6

BOL niv. 3/4 landbouw

HBO Agrarische bedrijfskunde

HBO Landbouw

HBO Veehouderij

BOL niv 3/4 techniek

HBO Elektrotechniek

HBO Bouwkunde

13

HBO Werktuigbouwkunde

BOL niv. 3/4 economie

HBO Commerciële economie

HBO Bedrijfseconomie

HBO Management, economie en recht

HBO Communicatie

BOL niv. 3/4 gezondheidszorg

HBO Opleiding tot verpleegkundige

HBO Facilitaire dienstverlening

BOL niv. 3/4 gedrag en maatschappij

HBO Sociaal pedagogische hulpverlening

HBO Leraar basisonderwijs

HBO Maatschappelijk werk en dienstverlening

HBO Leraar basisonderwijs

HBO Culturele en maatschappelijke vorming

HBO landbouw

WO Bedrijfskunde

HBO Master's opleiding Landbouw

WO Milieuhygiëne

HBO techniek

WO Bedrijfskunde

HBO Technische bedrijfskunde

WO Bouwkunde

WO Scheikunde

9

8

5

HBO economie

WO Bedrijfskunde

WO Bedrijfseconomie

WO Nederlands recht (ook OU)

HBO Accountancy

HBO gezondheidszorg

HBO Leraar speciaal onderwijs

WO Pedagogische wetenschappen

HBO gedrag en maatschappij

WO Pedagogische wetenschappen

WO Sociologie

WO Beleids- en organisatiewetenschappen

WO Nederlands recht (ook OU)

WO Sociaal-culturele wetenschappen

WO Psychologie (ook OU)

8
1
9
9
8
6


6
6
5

3
9


Tabel A2.2 (vervolg)

Belangrijkste opleidingen van schoolverlaters die een voltijd vervolgopleiding zijn gaan volgen

$\%$

HBO kunst en cultuur

HBO Uitvoerend musicus

$\mathrm{HBO} 2 \mathrm{e}$ fase Autonome beeldende kunst

HBO 2e fase Kunst en cultuur

HBO Kunst en cultuur

HBO Master's opleiding Kunst en cultuur

12

8

WO landbouw

$\mathrm{AlO} / \mathrm{OIO}$

79

WO techniek

$\mathrm{AlO} / \mathrm{OIO}$

Ontwerpersopleiding

WO economie

Post-doct. beroepsopl. Accountant

$\mathrm{AlO} / \mathrm{OIO}$

Post-doct. beroepsopl. Controller

Post-doct. beroepsopl. Registeraccountant

12

\section{WO gezondheidzorg}

AIO/OIO

Post-doct. beroepsopl. Huisarts

Post-doct. beroepsopl. Medisch specialist (AGIO)

WO gedrag en maatschappij

$\mathrm{AlO} / \mathrm{OIO}$

WO Kort Onderwijs

WO Nederlands recht (ook OU)

WO taal en cultuu

WO Kort Onderwijs

$\mathrm{AlO} / \mathrm{OIO}$

47

19

WO recht en openbare orde

$\mathrm{AlO} / \mathrm{OIO}$

WO Fiscaal-juridische opleiding

WO Notariële opleiding

Post-doct. beroepsopl. Advocatuur

Post-doct. beroepsopl. Kandidaat notaris opleiding

Post-doct. beroepsopl. Recht en openbare orde

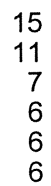

WO natuurwetenschappen

$\mathrm{AIO} / \mathrm{OIO}$

WO Kort Onderwijs

74

13

Toelichting

In de tabel zijn alleen die opleidingen opgenomen die door ten minste 5\% van de schoolverlaters worden gevolgd. 
Tabel A2.3

Oordeel van schoolverlaters over de aansluiting van de afgesloten opleiding met de voltijd vervolgopleiding

\begin{tabular}{|c|c|c|c|c|}
\hline Opleidingssector & $\begin{array}{c}\text { oordeel } \\
\text { goed } \\
\\
\%\end{array}$ & $\begin{array}{c}\text { oordeel } \\
\text { vol- } \\
\text { doende } \\
\%\end{array}$ & $\begin{array}{c}\begin{array}{c}\text { oordeel } \\
\text { matig }\end{array} \\
\%\end{array}$ & $\begin{array}{c}\text { oordeel } \\
\text { slecht } \\
\% \\
\%\end{array}$ \\
\hline
\end{tabular}

AVO
MAVO
HAVO
VWO
Totaal
VBO
IVBO*
landbouw
techniek
economie
gezondheidszorg
Totaal

BOL niv. $1 / 2$

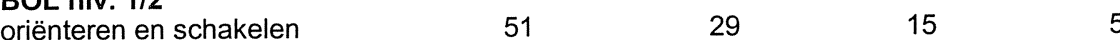

landbouw

techniek

economie

gezondheidszorg

$41 \quad 37$

$42 \quad 36$

$49-37$

$\begin{array}{ll}15 & 7 \\ 16 & 6 \\ 11 & 3 \\ 15 & 5\end{array}$

Totaal

$41 \quad 33$

$33 \quad 14 \quad 12$

37

37

46

46

35

33

$\begin{array}{rr}13 & 9 \\ 18 & 10\end{array}$

18

11

17
15

10

5

BOL niv. $3 / 4$

landbouw

techniek

economie

gezondheidszorg

gedrag en maatschappij

Totaal

$\begin{array}{rrrr}51 & 29 & 15 & 5 \\ 42 & 19 & 26 & 13 \\ 36 & 26 & 22 & 16 \\ 37 & 38 & 15 & 10 \\ 53 & 27 & 18 & 2 \\ 44 & 31 & 17 & 8\end{array}$

HBO

landbouw

onderwijs

techniek

economie

gezondheidszorg

gedrag en maatschappij

kunst en cultuur

Totaal

$\begin{array}{rrrr}29 & 33 & 25 & 13 \\ 37 & 42 & 15 & 6 \\ 32 & 38 & 21 & 9 \\ 39 & 35 & 19 & 8 \\ 38 & 39 & 18 & 6 \\ 35 & 38 & 19 & 7\end{array}$

Totaal

$\begin{array}{llrl}49 & 32 & 13 & 5 \\ 54 & 29 & 11 & 6 \\ 51 & 34 & 9 & 6 \\ 53 & 35 & 9 & 3 \\ 49 & 36 & 11 & 4 \\ 35 & 42 & 16 & 8 \\ 54 & 28 & 11 & 7 \\ 51 & 34 & 11 & 5 \\ 42 & 36 & 15 & 6\end{array}$

${ }^{\star}=$ betreft alleen IVBO Groen

Toelichting

Vraag in de enquête:

- Hoe vindt $u$ de aansluiting tussen uw [...] opleiding en deze vervolgopleiding?

Het gaat hier alleen om schoolverlaters die een voltijd vervolgopleiding zijn gaan volgen. 
Tabel A2.4

Doorstroom van schoolverlaters naar de beroepsbegeleidende leerweg

MAVO

OVDB

ECABO

Handel/L-OVD

BOL/BBL rest

SVH

VEV/LOB-E

HAVO

ECABO

$S V H$

OVDB

GOC

BOL/BBL rest

Handel/L-OVD

vwo

ECABO

OVDB

Handel/L-OVD

In-service Operatie-assistent

$\mathrm{SVH}$

MBO rest

IVBO

OVDB

LOBAS

Handel/L-OVD

SVB

ECABO

BOL/BBL rest

VBO landbouw

LOBAS

48

BOL/BBL rest

OVDB

Handel/L-OVD

VBO techniek

BOL/BBL rest

VEV/LOB-E

SOM

SVB

INNOVAM

VTL

18

18

15

11

VBO economie

ECABO

Handel/L-OVD

BOL/BBL rest

SVH

OVDB

VBO gezondheidszorg

OVDB

KOC

Handel/L-OVD

BOL/BBL rest

$\mathrm{MBO}$ rest 
Tabel A2.4 (vervolg)

Doorstroom van schoolverlaters naar de beroepsbegeleidende leerweg

BOL niv. $1 / 2$ oriënteren en schakelen

OVDB

Handel/L-OVD

$\mathrm{SVH}$

$\mathrm{BOL} / \mathrm{BBL}$ rest

BOL niv. 1/2 landbouw

LOBAS

ECABO

OVDB

SBW

$\mathrm{BOL} / \mathrm{BBL}$ rest

BOL niv. 1/2 techniek

VEV/LOB-E

SOM

Intechnium

SOB\&B

BOL/BBL rest

INNOVAM

BOL niv. $1 / 2$ economie

Handel/L-OVD

ECABO

BOL/BBL rest

OVDB

BOL niv. 1/2 gezondheidszorg

OVDB

KOC

BOL/BBL rest

BOL niv. 3/4 landbouw

LOBAS

BOL/BBL rest

SOM

SBW

ECABO

Handel/L-OVD

BOL niv. 3/4 techniek

VEV/LOB-E

BOL/BBL rest

INNOVAM

SOM

VOC-Car

SBW

OVDB

BOL niv. 3/4 economie

ECABO

$\mathrm{SVH}$

Handel/L-OVD

BOL/BBL rest

OVDB

BOL niv. $3 / 4$ gezondheidszorg

OVDB

In-service Ziekenverzorgende

$\mathrm{SVH}$

BOL/BBL rest 
Tabel A2.4 (vervolg)

Doorstroom van schoolverlaters naar de beroepsbegeleidende leerweg

BOL niv. 3/4 gedrag en maatschappij

OVDB

BOL/BBL rest

ECABO

Toelichting

In de tabel zijn alleen die opleidingen opgenomen die door ten minste $5 \%$ van de schoolverlaters worden gevolgd. 


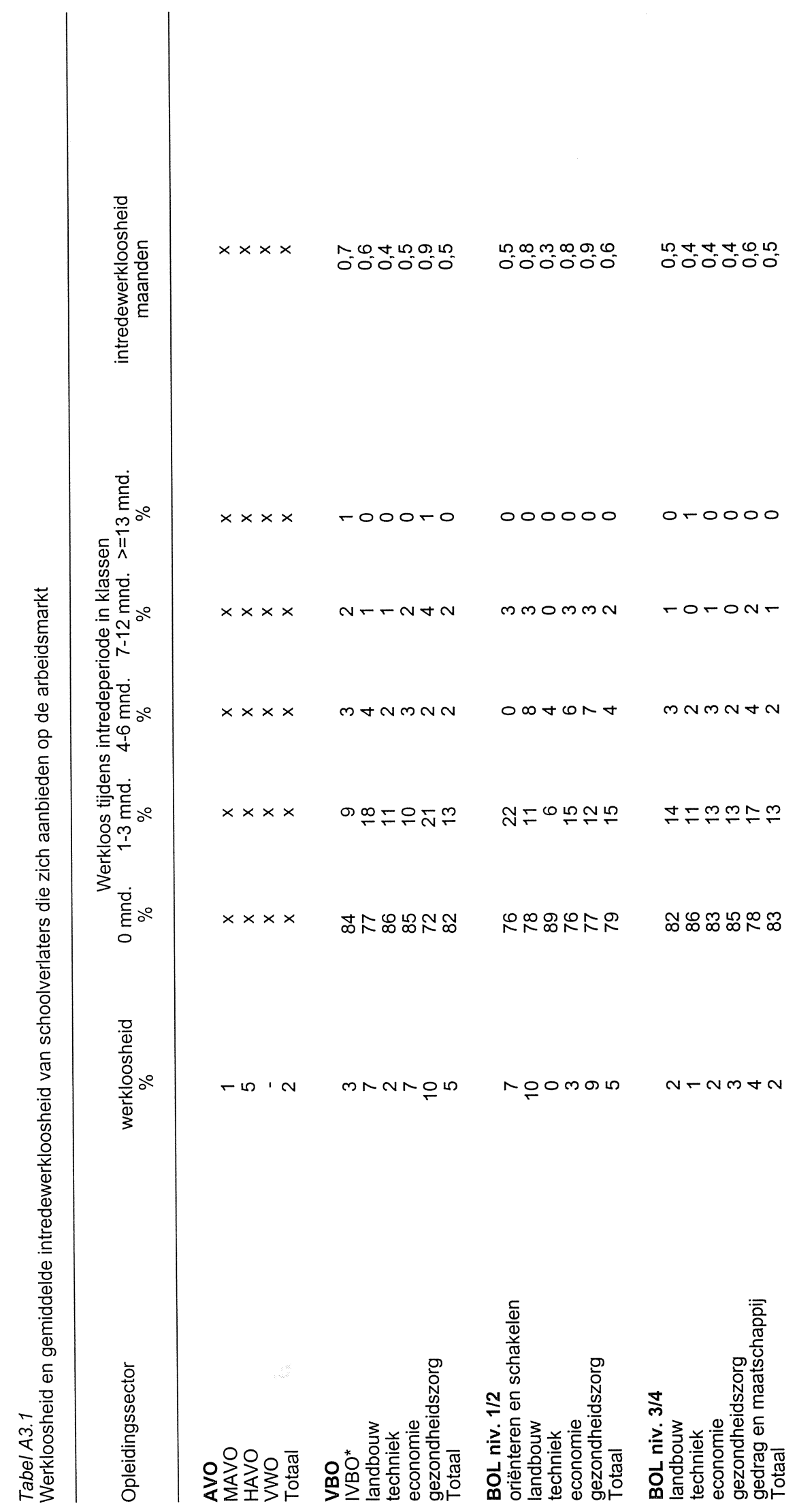




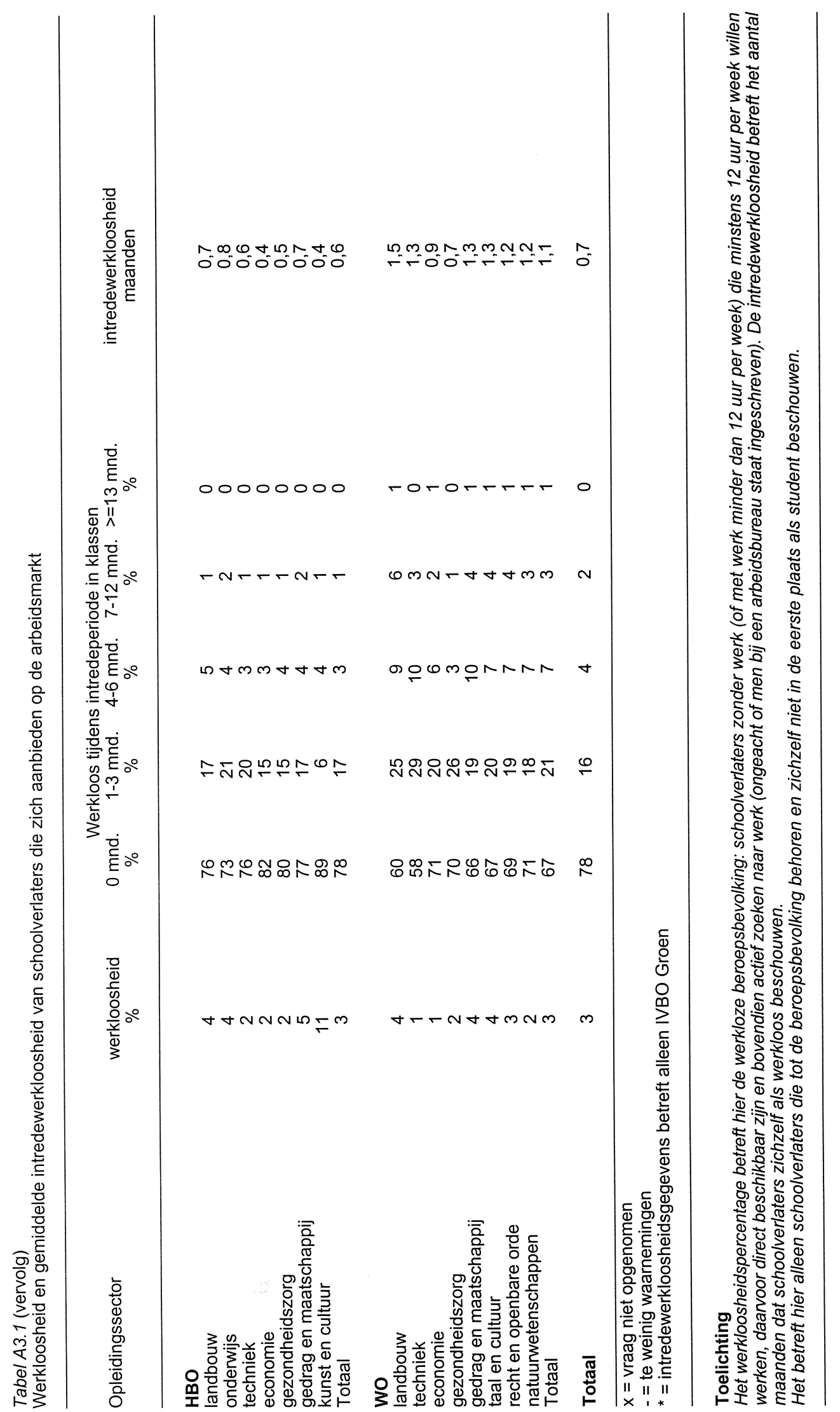




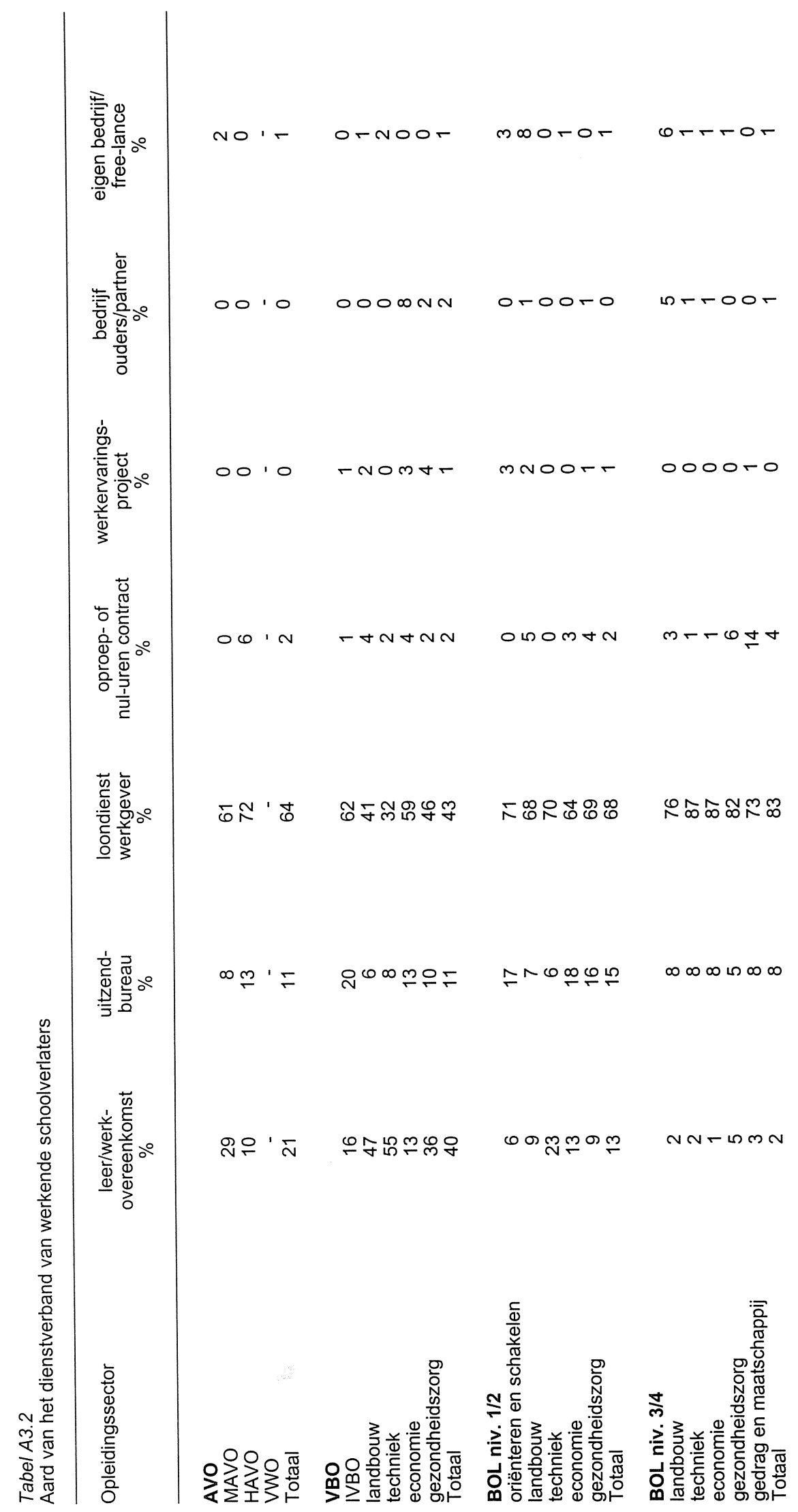




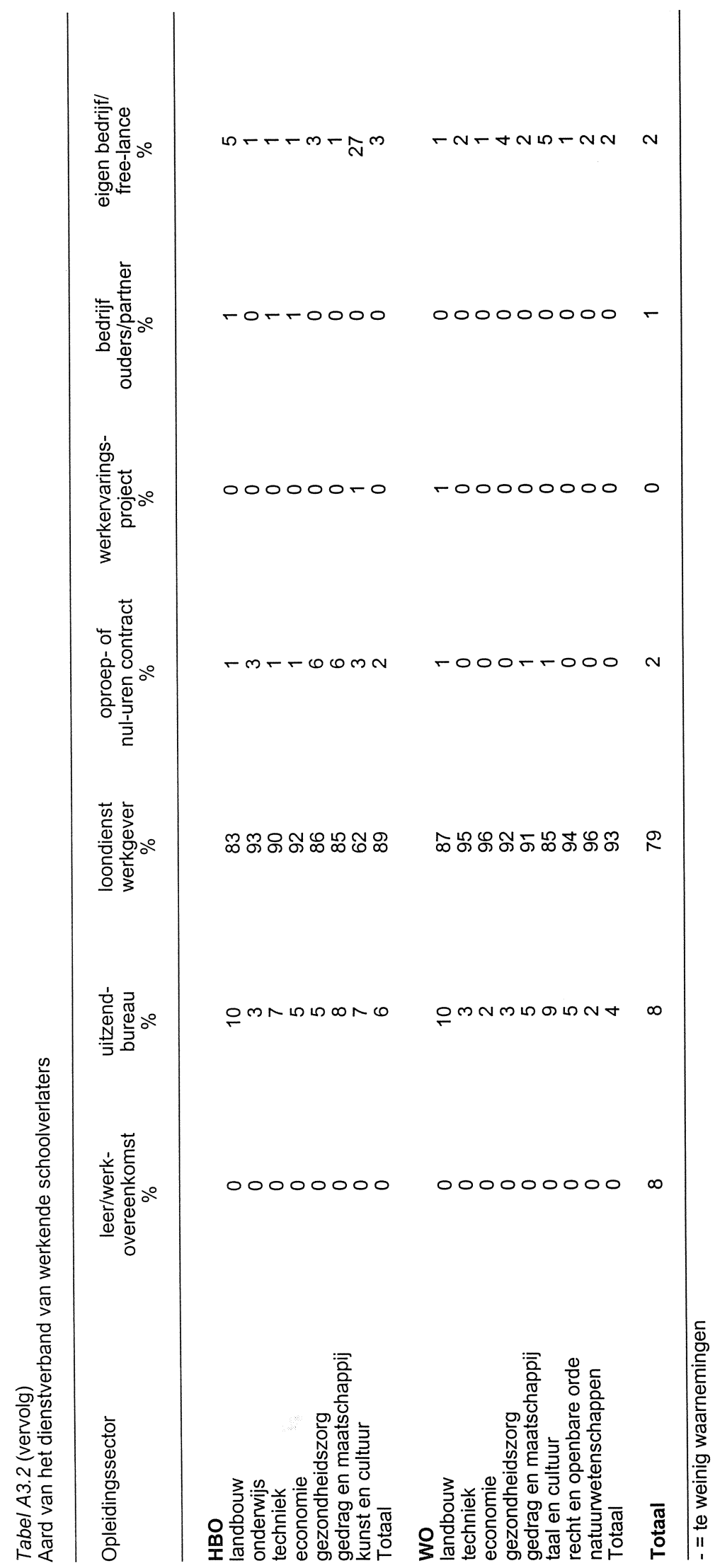


Tabel A3. 3

Percentage werkende schoolverlaters met een flexibele aanstelling

Opleidingssector

AVo

MAVO

HAVO

VWO

Totaal

VBO

IVBO

landbouw

techniek

20

economie

24

gezondheidszorg

19

Totaal

BOL niv. 1/2

oriënteren en schakelen $\quad 22$

landbouw

techniek

economie

12

gezondheidszorg

Totaal

30

BOL niv. 3/4

landbouw

techniek

economie

gezondheidszorg

gedrag en maatschappij

Totaal

HBO

landbouw

onderwijs

techniek

economie

gezondheidszorg

gedrag en maatschappij

kunst en cultuur

Totaal

Wo

landbouw

techniek

economie

gezondheidszorg

gedrag en maatschappij

taal en cultuur

recht en openbare orde

natuurwetenschappen

Totaal

Totaal

- = te weinig waarnemingen

\section{Toelichting}

Een flexibele aanstelling betreft een aanstelling als uitzendkracht, oproepkracht e.d. of een aanstelling in tijdelijke dienst met een contract korter dan een jaar. 


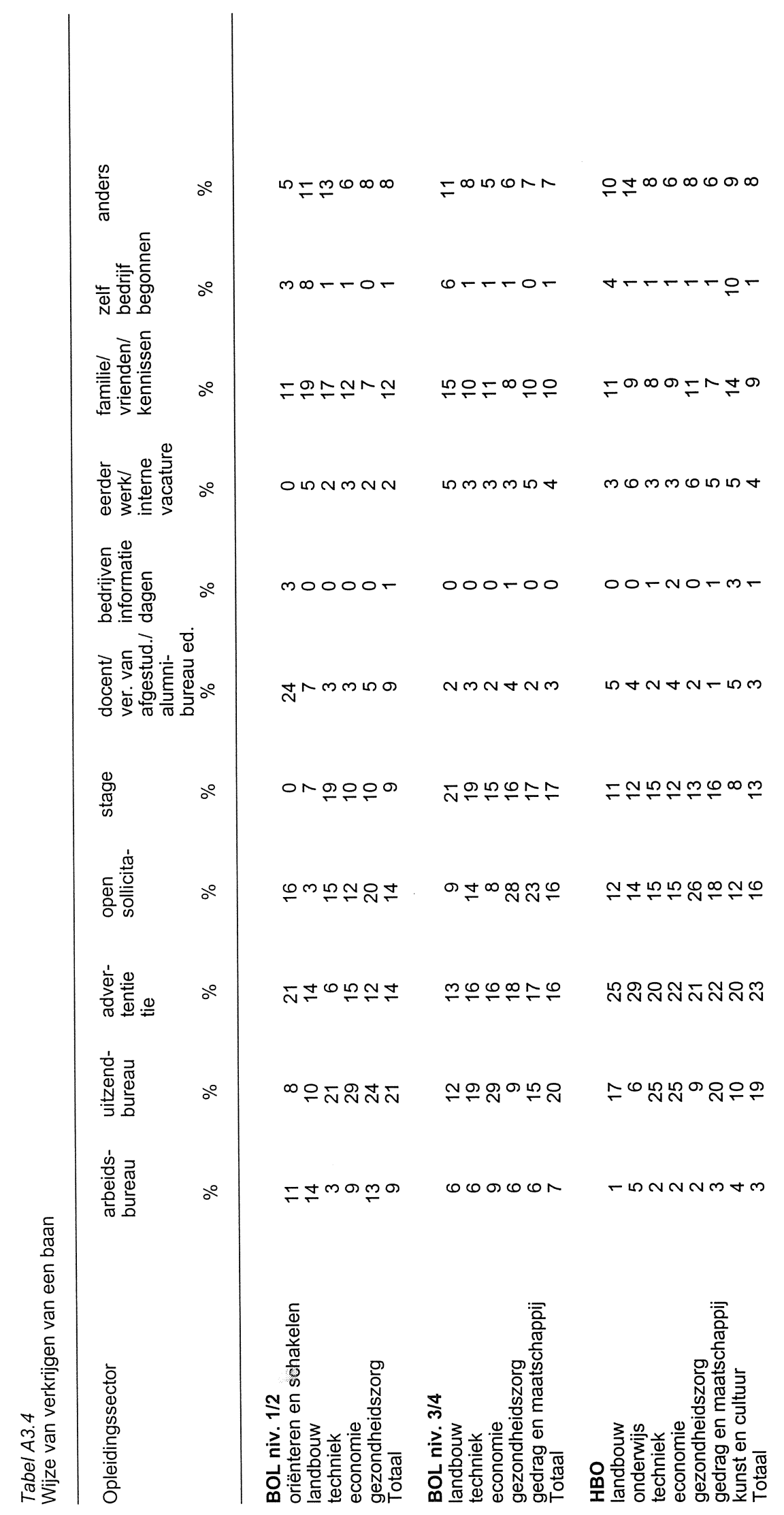




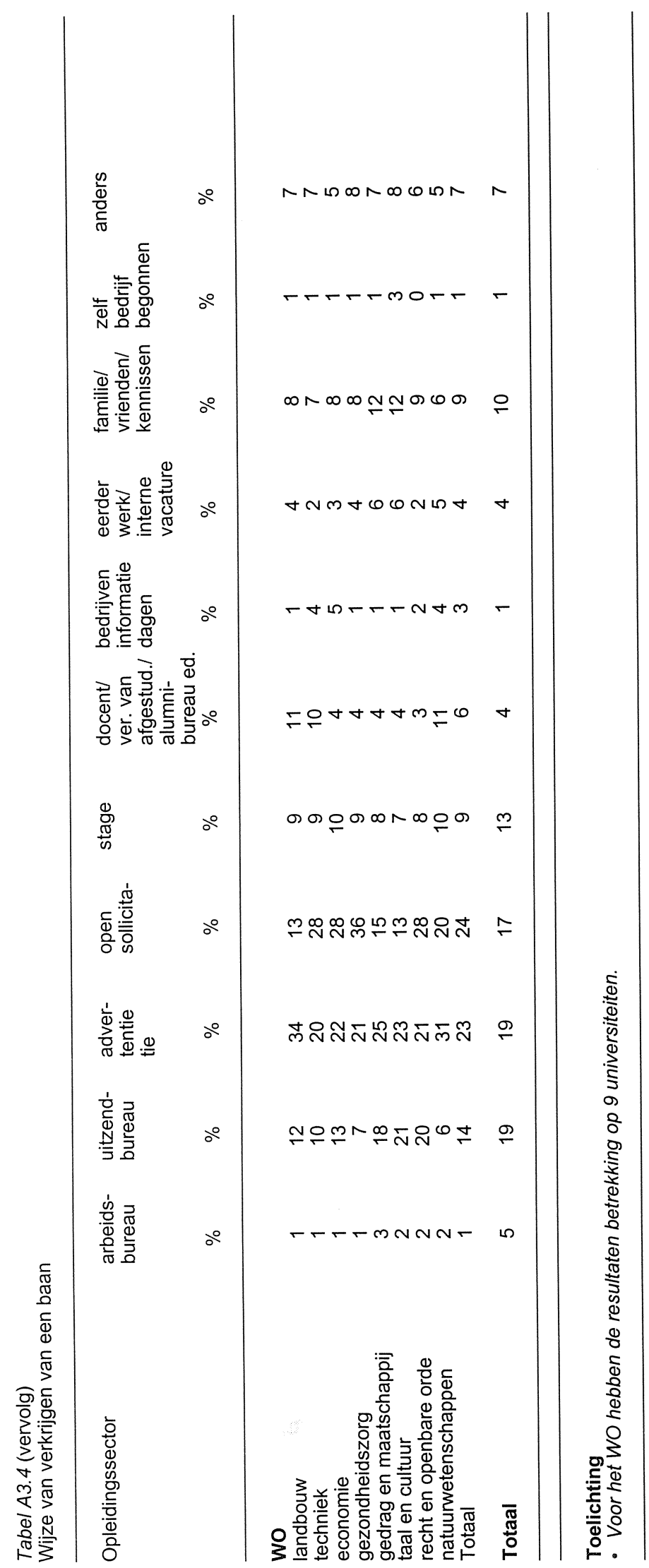


Tabel A3.5

Belangrijkste bedrijfsgroepen waarin schoolverlaters werkzaam zijn

MAVO

Niet-gespec. detailh. in winkel

Ov. gespec. detailh. in winkel

Gezondheidszorg

Welzijnszorg

Restaurants/cafetaria's/snackbars ed.

HAVO

Rechtsk dienstverl./account./belastingconsul./holdings ed.

Ov. gespec. detailh. in winkel

Gezondheidszorg

13

Akker-/tuinbouw

IVBO

Ov. gespec. detailh. in winke

Niet-gespec. detailh. in winkel

Slachterijen/vleesverwerking

Gespec. detailh. voed.-/genotmid. in winkel

Afwerken gebouwen

VBO landbouw

Ov. gespec. detailh. in winke

Dienstverl. tbv landb. (excl. veterin.dienst.)

Akker-/tuinbouw

Restaurants/cafetaria's/snackbars ed.

VBO techniek

Burgerl//utilit.;grond-/water-/wegenb. (excl. grondverz.) 21

Afwerken gebouwen

Bouwinstallatie

Handel in/repar. auto's (1)

Vervoer over weg

Ov. gespec. detailh. in winkel

Overheidsdienst.

VBO economie

Ov. gespec. detailh. in winkel

Niet-gespec. detailh. in winkel

Overheidsdienst.

Gespec. detailh. voed.-/genotmid. in winkel

\section{VBO gezondheidszorg}

Ov. dienstverlening

Ov. gespec. detailh. in winkel

Niet-gespec. detailh. in winke

Welzijnszorg

Restaurants/cafetaria's/snackbars ed.

Detailh. farmac./med. art./parfum/cosmet. in winkel

BOL niv. $1 / 2$ oriënteren en schakelen

Overheidsdienst.

Ov. gespec. detailh. in winkel

Niet-gespec. detailh. in winkel

Akker-/tuinbouw

BOL niv. 1/2 landbouw

Ov. gespec. detailh. in winkel

Niet-gespec. detailh. in winke

Veterinaire diensten

Fokken/houden dieren

Dienstverl. tbv landb. (excl. veterin.dienst.)

Akker-/tuinbouw 
Tabel A3.5 (vervolg)

Belangrijkste bedrijfsgroepen waarin schoolverlaters werkzaam zijn

BOL niv. 1/2 techniek

Bouwinstallatie

Burgerl./utilit.;grond-/water-/wegenb. (excl. grondverz.)

Overheidsdienst.

Handel in/repar. auto's (1)

BOL niv. 1/2 economie

Ov. gespec. detailh. in winkel

Niet-gespec. detailh. in winkel

Restaurants/cafetaria's/snackbars ed.

Hotels/pensions/conferentie-oorden

BOL niv. 1/2 gezondheidszorg

Welzijnszorg

Ov. dienstverlening

Gezondheidszorg

Niet-gespec. detailh. in winkel

Hotels/pensions/conferentie-oorden

BOL niv. $3 / 4$ landbouw

Ov. gespec. detailh. in winkel

Dienstverl. tbv landb. (excl. veterin.dienst.)

Akker-/tuinbouw

Fokken/houden dieren

BOL niv. 3/4 techniek

Burgerl./utilit.;grond-/water-/wegenb. (excl. grondverz.)

Bouwinstallatie

Architecten-/ingenieurs-/ov. techn.ontw.-/teken-/adviesbur.

Gezondheidszorg

BOL niv. 3/4 economie

Ov. gespec. detailh. in winkel

Geldscheppende financ. instell.

Rechtsk. dienstverl./account./belastingconsul./holdings ed.

Hotels/pensions/conferentie-oorden

BOL niv. 3/4 gezondheidszorg

Welzijnszorg

Gezondheidszorg

Detailh. farmac./med. art./parfum/cosmet. in winkel

Ov. dienstverlening

BOL niv. 3/4 gedrag en maatschappij

Welzijnszorg

HBO landbouw

Architecten-/ingenieurs-/ov. techn.ontw.-/teken-/adviesbur.

Openbaar bestuur

Akker-/tuinbouw

Rechtsk. dienstverl./account./belastingconsul./holdings ed.

HBO onderwijs

Basisonderwijs voor leerplichtingen/speciaal onderwijs

\section{HBO techniek}

Architecten-/ingenieurs-/ov. techn.ontw.-/teken-/adviesbur. Adviesbur. op gebied automat./systeemh.

Burgerl./utilit.;grond-/water-/wegenb. (excl. grondverz.) 
Tabel A3.5 (vervolg)

Belangrijkste bedrijfsgroepen waarin schoolverlaters werkzaam zijn

HBO economie

Rechtsk. dienstverl./account./belastingconsul./holdings ed.

Geldscheppende financ. instell.

Uitzendbur./uitleenbedr./arbeidsbemid./testen/werven/select.

Adviesbur. op gebied automat./systeemh.

HBO gezondheidszorg

Gezondheidszorg

Welzijnszorg

HBO gedrag en maatschappij

Welzijnszorg

Uitzendbur./uitleenbedr./arbeidsbemid./testen/werven/select.

Gezondheidszorg

HBO kunst en cultuur

Overig amusement/kunst

Reklamebureaus ed.

Ov. zakelijke dienstverl. n.e.g.

WO landbouw

Hoger onderwijs

Natuurwet. speur-/ontwikkelingsw.

Architecten-/ingenieurs-/ov. techn.ontw.-/teken-/adviesbur.

Openbaar bestuur

Adviesbur. op gebied automat./systeemh.

Rechtsk. dienstverl./account./belastingconsul./holdings ed.

WO techniek

Architecten-/ingenieurs-/ov. techn.ontw.-/teken-/adviesbur.

Hoger onderwijs

Adviesbur. op gebied automat./systeemh.

Rechtsk. dienstverl./account./belastingconsul./holdings ed.

Natuurwet. speur-/ontwikkelingsw.

WO economie

Rechtsk. dienstverl./account./belastingconsul./holdings ed.

Geldscheppende financ. instell.

Adviesbur. op gebied automat./systeemh.

Verzekeringsw./pensioenfonds. (excl. verpl. soc.verzek.)

WO gezondheidszorg

Gezondheidszorg

Veterinaire diensten

Welzijnszorg

Hoger onderwijs

WO gedrag en maatschappij

Openbaar bestuur

Rechtsk. dienstverl./account./belastingconsul./holdings ed.

Welzijnszorg

Gezondheidszorg

Hoger onderwijs

Uitzendbur./uitleenbedr./arbeidsbemid./testen/werven/select.

Adviesbur. op gebied automat./systeemh. 
Tabel A3.5 (vervolg)

Belangrijkste bedrijfsgroepen waarin schoolverlaters werkzaam zijn

Wo taal en cultuur

Uitgeverijen

Hoger onderwijs

Voortgezet onderwijs

Openbaar bestuur

Adviesbur. op gebied automat./systeemh.

Rechtsk. dienstverl./account./belastingconsul./holdings ed.

Uitzendbur./uitleenbedr./arbeidsbemid./testen/werven/select.

9
7
7
6
6
6
6

WO recht en openbare orde

Rechtsk. dienstverl./account./belastingconsul./holdings ed.

Openbaar bestuur

Overheidsdienst.

Geldscheppende financ. instell.

WO natuurwetenschappen

Hoger onderwijs

Adviesbur. op gebied automat./systeemh.

Detailh farmac/med. art./parfum/cosmet. in winkel

Architecten-/ingenieurs-/ov. techn.ontw.-/teken-/adviesbur.

Natuurwet. speur-/ontwikkelingsw.

Gezondheidszorg

\section{Toelichting}

De bedrijven waarin de schoolverlaters werkzaam zijn, zijn geclassificeerd volgens de Standaard Bedrijfs Indeling van het CBS. Op het hier gepresenteerde niveau van bedrijfsgroepen worden in totaal 211 categorieën onderscheiden.

In de tabel zijn alleen die bedrijfsgroepen weergegeven waarin ten minste $5 \%$ van de schoolverlaters werkzaam is. 
Tabel A3.6

Belangrijkste beroepsgroepen waarin schoolverlaters werkzaam zijn

MAVO

Verkopers

Hulpkrachten horeca en verzorging

Verpleeghulpen en leerling-verpleegkundigen

Receptionisten en administratieve employés

Boekhouders en secretaresses

Verzorgend personeel

HAVO

Receptionisten en administratieve employés

Boekhouders en secretaresses

Verkopers

Productieplanners

Verpleeghulpen en leerling-verpleegkundigen

Commercieel employés

Hulpkrachten horeca en verzorging

IVBO

Verkopers

Bouwvakkers

Metaalarbeiders

Mechanisch operators

Laders en lossers

Agrarische arbeider

\section{VBO landbouw}

Verkopers

Agrarische arbeider

Hulpkrachten horeca en verzorging

Bouwvakkers

Laders en lossers

Interieurverzorger

VBO techniek

Bouwvakkers

Assembleurs

Laders en lossers

Productiemedewerker

Monteurs

Metaalarbeiders

VBO economie

Verkopers

Receptionisten en administratieve employés

Laders en lossers

Aspirant politieagenten, soldaten en beveiligingshulpkrachten

Productiemedewerker

Hulpkrachten horeca en verzorging

VBO gezondheidszorg

Hulpkrachten horeca en verzorging

Verkopers

Productiemedewerker

Verzorgend personeel

BOL niv. 1/2 oriënteren en schakelen

Verkopers

Aspirant politieagenten, soldaten en beveiligingshulpkrachten

Agrarische arbeider

Laders en lossers

Interieurverzorger

Receptionisten en administratieve employés

Hulpkrachten horeca en verzorging 
Tabel A3.6 (vervolg)

Belangrijkste beroepsgroepen waarin schoolverlaters werkzaam zijn

BOL niv. 1/2 landbouw

Verkopers

Agrarische arbeider

Verplegenden en doktersassistenten

Winkeliers

Chauffeurs

BOL niv. 1/2 techniek

Elektromonteurs

Monteurs

Metaalarbeiders

Monteurs en controleurs elektrotechnische producten

Aannemers en installateurs

Bouwvakkers

Elektronicamonteurs

12

BOL niv. 1/2 economie

Verkopers

Receptionisten en administratieve employés

Boekhouders en secretaresses

Hulpkrachten horeca en verzorging

Verzorgend personeel

BOL niv. 1/2 gezondheidszorg

Hulpkrachten horeca en verzorging

Verzorgend personeel

Interieurverzorger

Verkopers

Verpleeghulpen en leerling-verpleegkundigen

Receptionisten en administratieve employés

BOL niv. 3/4 landbouw

Agrarische arbeider

Agrarische bedrijfshoofden

Verkopers

Agrarische vakkrachten

BOL niv. 3/4 techniek

Monteurs

Aannemers en installateurs

Elektromonteurs

Elektronicamonteurs

Programmeurs

BOL niv. 3/4 economie

Boekhouders en secretaresses

Commercieel employés

Receptionisten en administratieve employés

Verkopers

Winkeliers

BOL niv. 3/4 gezondheidszorg

Verzorgend personeel

Verplegenden en doktersassistenten

Apothekersassistenten en medisch laboranten

Ziekenverzorgenden

Verkopers 
Tabel A3.6 (vervolg)

Belangrijkste beroepsgroepen waarin schoolverlaters werkzaam zijn

BOL niv. $3 / 4$ gedrag en maatschappij

Verzorgend personeel

Activiteitenbegeleiders en medewerkers arbeidsbemiddeling

Hulpkrachten horeca en verzorging

Receptionisten en administratieve employés

Verkopers

HBO landbouw

Milieuhygienisten en agrarisch vertegenwoordigers

Commercieel medewerkers

Agrarische bedrijfshoofden

Commercieel employés

Procestechnologen

Organisatie-adviseurs

Systeemanalisten

Procesoperators

HBO onderwijs

Leraar basisonderwijs

Docenten talen en expressie

Docenten sociale vakken (2e en $3 e$ gr.)

HBO techniek

Systeemanalisten

Architecten en bouwkundig projectleiders

Werktuigbouwkundig ontwerpers en hoofden technische dienst

Technisch systeemanalisten

Organisatie-adviseurs

HBO economie

Commercieel medewerkers

Commercieel employés

Assistent accountants

Systeemanalisten

Boekhouders en secretaresses

Organisatie-adviseurs

Activiteitenbegeleiders en medewerkers arbeidsbemiddeling

HBO gezondheidszorg

Therapeuten en verpleegkundigen

HBO gedrag en maatschappij

Sociaal-cultureel werkers

Activiteitenbegeleiders en medewerkers arbeidsbemiddeling

Verzorgend personeel

HBO kunst en cultuur

Kunstenaars

Docenten talen en expressie

Architecten en bouwkundig projectleiders

WO landbouw

Natuurwetenschappers

Milieuhygienisten en agrarisch vertegenwoordigers

Landbouwkundigen

Systeemanalisten

Commercieel medewerkers

Materiaalkundigen 
Tabel A3.6 (vervolg)

Belangrijkste beroepsgroepen waarin schoolverlaters werkzaam zijn

$\%$

WO techniek

Weg- en waterbouwkundigen 13

Systeemanalisten

Materiaalkundigen

Werktuigbouwkundigen

Organisatiedeskundigen

Elektrotechnici

Architecten en bouwkundig projectleiders

13

13

9

WO economie

Commercieel medewerkers

Systeemanalisten

Assistent accountants

Economen

Organisatiedeskundigen

Organisatie-adviseurs

WO gezondheidszorg

Artsen

WO gedrag en maatschappij

Sociaal-wetenschappelijk onderzoekers 15

Sociaal-cultureel werkers 10

Commercieel medewerkers

Systeemanalisten

$\begin{array}{ll}\text { Onderwijskundigen en pedagogen } & 5 \\ \text { Juristen } & 5\end{array}$

Organisatie-adviseurs 5

WO taal en cultuur

Commercieel medewerkers 15

Systeemanalisten 6

Journalisten

Taalkundigen

Docenten letteren (1e gr. en WO)

Boekhouders en secretaresses

Commercieel employés

WO recht en openbare orde

Juristen

Commercieel medewerkers

WO natuurwetenschappen

Natuurwetenschappers

Systeemanalisten

Apothekers

Materiaalkundigen

Toelichting

De beroepen waarin de schoolverlaters werkzaam zijn, zijn geclassificeerd volgens de Standaard Beroepenclassificatie 1992 van het CBS. Binnen de elementaire beroepen is hierbij door het ROA een nader onderscheid gemaakt. Bovendien zijn de namen van de beroepen verduidelijkt. Op het hier gepresenteerde niveau van beroepsgroepen worden in totaal 127 categorieën onderscheiden.

In de tabel zijn alleen die beroepsgroepen weergegeven waarin ten minste $5 \%$ van de schoolverlaters werkzaam is. 
Tabel A3.7

Grootte van de organisatie waarin schoolverlaters werkzaam zijn

\begin{tabular}{|c|c|c|c|c|c|}
\hline Opleidingssector & $\begin{array}{c}1 \text { pers } \\
\%\end{array}$ & $\begin{array}{c}2 \mathrm{t} / \mathrm{m} 9 \\
\text { pers } \\
\%\end{array}$ & $\begin{array}{l}10 \mathrm{t} / \mathrm{m} 99 \\
\text { pers } \\
\%\end{array}$ & $\begin{array}{c}100 \mathrm{t} / \mathrm{m} \\
999 \text { pers } \\
\%\end{array}$ & $\begin{array}{c}>=1000 \\
\text { pers } \\
\%\end{array}$ \\
\hline \multicolumn{6}{|l|}{ VBO } \\
\hline IVBO* $^{*}$ & 4 & 32 & 36 & 16 & 12 \\
\hline landbouw & 3 & 42 & 32 & 9 & 14 \\
\hline techniek & 2 & 15 & 53 & 19 & 12 \\
\hline economie & 0 & 20 & 34 & 26 & 20 \\
\hline gezondheidszorg & 0 & 29 & 38 & 18 & 15 \\
\hline Totaal & 1 & 21 & 45 & 19 & 14 \\
\hline \multicolumn{6}{|l|}{ BOL niv. $1 / 2$} \\
\hline oriënteren en schakelen & 3 & 18 & 21 & 18 & 39 \\
\hline landbouw & 1 & 37 & 50 & 10 & 2 \\
\hline techniek & 0 & 23 & 40 & 17 & 19 \\
\hline economie & 0 & 19 & 36 & 21 & 24 \\
\hline gezondheidszorg & 1 & 17 & 34 & 28 & 20 \\
\hline Totaal & 1 & 20 & 33 & 20 & 26 \\
\hline \multicolumn{6}{|l|}{ BOL niv. $3 / 4$} \\
\hline $\begin{array}{l}\text { landbouw } \\
\text { techniek }\end{array}$ & 5 & $\begin{array}{l}44 \\
10\end{array}$ & 29 & 13 & 9 \\
\hline $\begin{array}{l}\text { techniek } \\
\text { economie }\end{array}$ & 1 & $\begin{array}{l}10 \\
17\end{array}$ & 37 & 26 & 27 \\
\hline economie & 0 & 17 & 34 & 23 & 25 \\
\hline gezondheidszorg & 1 & 21 & 30 & 28 & 20 \\
\hline gedrag en maatschappij & 0 & 8 & 32 & 39 & 20 \\
\hline Totaal & 1 & 17 & 33 & 26 & 22 \\
\hline \multicolumn{6}{|l|}{ HBO } \\
\hline landbouw & 1 & 12 & 24 & 35 & 28 \\
\hline onderwijs & 0 & 7 & 60 & 24 & 8 \\
\hline techniek & 0 & 6 & 26 & 30 & 38 \\
\hline economie & 0 & 6 & 25 & 28 & 40 \\
\hline gezondheidszorg & 2 & 18 & 15 & 33 & 32 \\
\hline gedrag en maatschappij & 0 & 5 & 23 & 46 & 27 \\
\hline kunst en cultuur & 15 & 26 & 37 & 16 & 6 \\
\hline Totaal & 1 & 8 & 30 & 30 & 30 \\
\hline \multicolumn{6}{|l|}{ wo } \\
\hline landbouw & 0 & 4 & 19 & 31 & 45 \\
\hline techniek & 0 & 5 & 18 & 38 & 39 \\
\hline economie & 0 & 3 & 13 & 39 & 45 \\
\hline gezondheidszorg & 0 & 15 & 12 & 44 & 28 \\
\hline gedrag en maatschappij & 1 & 7 & 27 & 45 & 20 \\
\hline taal en cultuur & 2 & 10 & 30 & 41 & 18 \\
\hline recht en openbare orde & 0 & 8 & 26 & 41 & 24 \\
\hline natuurwetenschappen & 0 & 5 & 22 & 49 & 24 \\
\hline Totaal & 1 & 7 & 21 & 41 & 30 \\
\hline Totaal & 1 & 13 & 32 & 29 & 26 \\
\hline
\end{tabular}

Toelichting

- Vraag in de enquête: Hoeveel mensen werken er bij de organisatie of het bedrijf waar u werkzaam bent. Het gaat hier om alle werknemers van het totale concern (hoofd- en nevenvestigingen samen).

- Voor het WO hebben de resultaten betrekking op 9 universiteiten. 
Tabel A3.8

Beloning van werkende schoolverlaters

\begin{tabular}{|c|c|c|}
\hline Opleidingssector & $\begin{array}{l}\text { gemiddeld } \\
\text { bruto maandloon } \\
\text { guldens }\end{array}$ & $\begin{array}{l}\text { gemiddeld } \\
\text { bruto uurloon } \\
\text { guldens }\end{array}$ \\
\hline \multicolumn{3}{|l|}{ AVO } \\
\hline MAVO & 1.285 & 8,64 \\
\hline HAVO & 1.785 & 11,95 \\
\hline $\begin{array}{l}\text { VWO } \\
\text { Totaal }\end{array}$ & $1.499^{-}$ & 10,11 \\
\hline Totaal & & \\
\hline \multicolumn{3}{|l|}{ VBO } \\
\hline IVBO & 1.239 & 8,04 \\
\hline landbouw & 1.109 & 8,09 \\
\hline techniek & 1.328 & 8,93 \\
\hline economie & 1.239 & 8,60 \\
\hline gezondheidszorg & 1.056 & 7,86 \\
\hline Totaal & 1.242 & 8,53 \\
\hline \multicolumn{3}{|l|}{ BOL niv. 1/2 } \\
\hline oriënteren en schakelen & 1.699 & 10,63 \\
\hline landbouw & 1.518 & 10,11 \\
\hline techniek & 2.032 & 12,62 \\
\hline economie & 1.966 & 13,72 \\
\hline gezondheidszorg & 1.604 & 11,86 \\
\hline Totaal & 1.865 & 12,41 \\
\hline \multicolumn{3}{|l|}{ BOL niv. $3 / 4$} \\
\hline landbouw & 2.452 & 15,21 \\
\hline techniek & 2.977 & 17,82 \\
\hline economie & 2.393 & 14,78 \\
\hline gezondheidszorg & 2.213 & 15,88 \\
\hline gedrag en maatschappij & 2.199 & 17,09 \\
\hline Totaal & 2.475 & 16,07 \\
\hline \multicolumn{3}{|l|}{ HBO } \\
\hline landbouw & 3.528 & 21,28 \\
\hline onderwijs & 3.470 & 23,11 \\
\hline techniek & 3.826 & 22,70 \\
\hline economie & 3.622 & 21,93 \\
\hline gezondheidszorg & 3.128 & 23,70 \\
\hline gedrag en maatschappij & 3.107 & 21,84 \\
\hline kunst en cultuur & 2.597 & 22,50 \\
\hline Totaal & 3.498 & 22,45 \\
\hline \multicolumn{3}{|l|}{ WO } \\
\hline landbouw & 3.700 & $\begin{array}{l}23,32 \\
25,93\end{array}$ \\
\hline techniek & $\begin{array}{l}4.354 \\
4.594\end{array}$ & $\begin{array}{l}25,93 \\
27,45\end{array}$ \\
\hline $\begin{array}{l}\text { economie } \\
\text { gezondheidszorg }\end{array}$ & $\begin{array}{l}4.594 \\
4.883\end{array}$ & 30,73 \\
\hline gedrag en maatschappij & 3.829 & 26,15 \\
\hline taal en cultuur & 3.554 & 24,51 \\
\hline recht en openbare orde & 4.530 & 25,34 \\
\hline natuurwetenschappen & 3.738 & 23,23 \\
\hline Totaal & 4.204 & 26,16 \\
\hline Totaal & 2.880 & 18,49 \\
\hline
\end{tabular}

- = te weinig waarnemingen

\section{Toelichting}

Dit betreft het bruto inkomen in de baan waarin men het hoogste aantal uren werkt. Dit is inclusief toeslagen voor ploegendienst, fooien, provisie e.d., maar exclusief inkomen uit overwerk, vakantiegeld, 13e maand, uitkering, e.d. Er is hier niet gecorrigeerd voor verschillen in leeftijd van de schoolverlaters. 
Tabel A3.9

Vereist opleidingsniveau voor de huidige functie volgens de werkgever

\begin{tabular}{|c|c|c|c|}
\hline Opleidingssector & $\begin{array}{l}\text { lager } \\
\%\end{array}$ & $\underset{\%}{\text { zelfde }}$ & $\begin{array}{c}\text { hoger } \\
\%\end{array}$ \\
\hline \multicolumn{4}{|l|}{ AVO } \\
\hline $\begin{array}{l}\text { MAVO } \\
\text { HAVO }\end{array}$ & $\begin{array}{l}18 \\
31\end{array}$ & $\begin{array}{l}65 \\
47\end{array}$ & $\begin{array}{l}17 \\
22\end{array}$ \\
\hline VWO & 31 & $4 !$ & 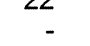 \\
\hline Totaal & 23 & 59 & 17 \\
\hline \multicolumn{4}{|l|}{ VBO } \\
\hline IVBO* $^{*}$ & $\bar{c}^{2}$ & & $e^{-}$ \\
\hline landbouw & 35 & 58 & 8 \\
\hline techniek & 16 & 76 & 8 \\
\hline economie & 25 & 67 & 8 \\
\hline $\begin{array}{l}\text { gezondheidszorg } \\
\text { Totaal }\end{array}$ & 30 & 64 & 6 \\
\hline Totdal & $\angle 2$ & & \\
\hline \multicolumn{4}{|l|}{ BOL niv. $1 / 2$} \\
\hline $\begin{array}{l}\text { oriënteren en schakelen } \\
\text { landbouw }\end{array}$ & $\begin{array}{l}92 \\
59\end{array}$ & $\begin{array}{r}0 \\
23\end{array}$ & 8 \\
\hline $\begin{array}{l}\text { landbouw } \\
\text { techniek }\end{array}$ & $\begin{array}{l}59 \\
46\end{array}$ & $\begin{array}{l}23 \\
41\end{array}$ & $\begin{array}{l}18 \\
13\end{array}$ \\
\hline $\begin{array}{l}\text { techniek } \\
\text { economie }\end{array}$ & $\begin{array}{l}46 \\
46\end{array}$ & 28 & 26 \\
\hline gezondheidszorg & 57 & 21 & 22 \\
\hline Totaal & 59 & 23 & 18 \\
\hline \multicolumn{4}{|l|}{ BOL niv. $3 / 4$} \\
\hline landbouw & 38 & 61 & 1 \\
\hline techniek & 23 & 75 & 3 \\
\hline $\begin{array}{l}\text { economie } \\
\text { gezondheidszorg }\end{array}$ & $\begin{array}{l}24 \\
27\end{array}$ & $\begin{array}{l}74 \\
72\end{array}$ & $\begin{array}{l}2 \\
1\end{array}$ \\
\hline $\begin{array}{l}\text { gezondheidszorg } \\
\text { gedrag en maatschappij }\end{array}$ & $\begin{array}{l}27 \\
26\end{array}$ & 72 & 3 \\
\hline Totaal & 25 & 73 & 2 \\
\hline \multicolumn{4}{|l|}{ HBO } \\
\hline landbouw & 20 & 79 & 1 \\
\hline onderwijs & 10 & 89 & 0 \\
\hline techniek & 15 & 83 & 1 \\
\hline economie & 22 & 77 & 1 \\
\hline gezondheidszorg & 15 & 85 & 0 \\
\hline gedrag en maatschappij & 35 & 65 & 0 \\
\hline kunst en cultuur & 35 & 64 & 1 \\
\hline Totaal & 20 & 79 & 1 \\
\hline \multicolumn{4}{|l|}{ wo } \\
\hline landbouw & 40 & 60 & \\
\hline techniek & 35 & 65 & \\
\hline economie & 43 & 57 & \\
\hline gezondheidszorg & $\begin{array}{r}9 \\
50\end{array}$ & $\begin{array}{l}91 \\
50\end{array}$ & \\
\hline $\begin{array}{l}\text { gedrag en maatschappij } \\
\text { taal en cultuur }\end{array}$ & 62 & 38 & \\
\hline recht en openbare orde & 24 & 76 & \\
\hline natuurwetenschappen & 32 & 68 & \\
\hline Totaal & 38 & 62 & \\
\hline Totaal & 29 & 67 & 4 \\
\hline
\end{tabular}

- = te weinig waarnemingen

* $=$ betreft alleen IVBO Groen

Toelichting

Vraag in de enquête:

- Welk opleidingsniveau werd cooor uw werkgever voor deze functie minimaal vereist? 
Tabel A3.10

Vereiste opleidingsrichting voor de huidige functie volgens de werkgever

\begin{tabular}{|c|c|c|c|}
\hline Opleidingssector & $\begin{array}{l}\text { eigen/ } \\
\text { verwante } \\
\text { richting } \\
\%\end{array}$ & $\begin{array}{c}\text { andere } \\
\text { richting } \\
\%\end{array}$ & $\begin{array}{c}\text { geen } \\
\text { richting } \\
\%\end{array}$ \\
\hline \multicolumn{4}{|l|}{ VBO } \\
\hline IVBO* & 34 & 11 & 55 \\
\hline landbouw & 40 & 7 & 53 \\
\hline techniek & 61 & 8 & 31 \\
\hline economie & 34 & 7 & 59 \\
\hline gezondheidszorg & 40 & 3 & 58 \\
\hline Totaal & 50 & 7 & \\
\hline \multicolumn{4}{|l|}{ BOL niv. $1 / 2$} \\
\hline oriënteren en schakelen & 27 & 19 & 54 \\
\hline landbouw & 59 & 2 & 39 \\
\hline techniek & 68 & 3 & 30 \\
\hline economie & 44 & 10 & 46 \\
\hline gezondheidszorg & 45 & 6 & 50 \\
\hline Totaal & 45 & 10 & 45 \\
\hline \multicolumn{4}{|l|}{ BOL niv. $3 / 4$} \\
\hline landbouw & 63 & 6 & 31 \\
\hline techniek & 81 & 3 & 16 \\
\hline economie & 60 & 10 & 29 \\
\hline gezondheidszorg & 78 & 5 & 17 \\
\hline gedrag en maatschappij & 69 & 7 & 24 \\
\hline Totaal & 70 & 7 & 23 \\
\hline \multicolumn{4}{|l|}{ HBO } \\
\hline landbouw & 75 & 5 & 20 \\
\hline onderwijs & 85 & 4 & 10 \\
\hline techniek & 81 & 3 & 16 \\
\hline economie & 67 & 6 & 27 \\
\hline gezondheidszorg & 92 & 3 & 5 \\
\hline gedrag en maatschappij & 76 & 6 & 18 \\
\hline kunst en cultuur & 67 & 9 & 24 \\
\hline $\begin{array}{l}\text { Totaal } \\
\text { Tolu }\end{array}$ & 77 & 5 & 18 \\
\hline \multicolumn{4}{|l|}{ wo } \\
\hline landbouw & 75 & 7 & 18 \\
\hline techniek & 78 & 3 & 19 \\
\hline economie & 75 & 1 & 23 \\
\hline gezondheidszorg & 95 & 2 & 3 \\
\hline gedrag en maatschappij & 59 & 8 & 32 \\
\hline taal en cultuur & 44 & 9 & 47 \\
\hline recht en openbare orde & 80 & 3 & 17 \\
\hline natuurwetenschappen & 78 & 3 & 19 \\
\hline Totaal & 72 & 4 & 24 \\
\hline Totaal & 67 & 6 & 27 \\
\hline
\end{tabular}

* = betreft alleen IVBO Groen

Toelichting

Vraag in de enquête: Welke opleidingsrichting werd door uw werkgever voor deze functie vereist? 
Tabel A3.11

Gewenste en feitelijke wekelijkse arbeidsduur van werkende schoolverlaters

\begin{tabular}{|c|c|c|}
\hline Opleidingssector & $\begin{array}{l}\text { gewenste wekelijkse } \\
\text { arbeidsduur } \\
\text { uren }\end{array}$ & $\begin{array}{c}\text { feitelijke wekelijkse } \\
\text { arbeidsduur } \\
\text { uren }\end{array}$ \\
\hline \multicolumn{3}{|l|}{ AVO } \\
\hline MAVO & 35,4 & 34,1 \\
\hline HAVO & 35,5 & 35,0 \\
\hline VWO & & - \\
\hline Totaal & 35,6 & 34,3 \\
\hline \multicolumn{3}{|l|}{ VBO } \\
\hline IVBO & 37,6 & 35,5 \\
\hline landbouw & 36,1 & 32,1 \\
\hline techniek & 38,9 & 34,7 \\
\hline economie & 35,9 & 32,9 \\
\hline gezondheidszorg & 34,0 & 31,2 \\
\hline Totaal & 37,2 & 33,8 \\
\hline \multicolumn{3}{|l|}{ BOL niv. $1 / 2$} \\
\hline oriënteren en schakelen & 37,4 & 36,2 \\
\hline landbouw & 39,2 & 38,4 \\
\hline techniek & 39,5 & $\begin{array}{l}37,6 \\
357\end{array}$ \\
\hline $\begin{array}{l}\text { economie } \\
\text { gezondheidszorg }\end{array}$ & $\begin{array}{l}37,0 \\
34,8\end{array}$ & $\begin{array}{l}35,7 \\
32,1\end{array}$ \\
\hline $\begin{array}{l}\text { gezondheidszorg } \\
\text { Totaal }\end{array}$ & $\begin{array}{l}34,8 \\
37,5\end{array}$ & 35,9 \\
\hline \multicolumn{3}{|l|}{ BOL niv. $3 / 4$} \\
\hline landbouw & 40,5 & 39,9 \\
\hline techniek & 39,8 & 39,4 \\
\hline economie & 38,5 & 38,4 \\
\hline gezondheidszorg & 35,4 & 33,9 \\
\hline gedrag en maatschappij & 34,5 & 31,8 \\
\hline Totaal & 37,7 & 36,9 \\
\hline \multicolumn{3}{|l|}{ HBO } \\
\hline landbouw & 39,9 & 39,7 \\
\hline $\begin{array}{l}\text { onderwijs } \\
\text { techniek }\end{array}$ & 34,4 & 34,5 \\
\hline $\begin{array}{l}\text { techniek } \\
\text { economie }\end{array}$ & $\begin{array}{l}38,8 \\
38,0\end{array}$ & $\begin{array}{l}39,5 \\
38,6\end{array}$ \\
\hline gezondheidszorg & 34,4 & 33,3 \\
\hline gedrag en maatschappij & 34,0 & 34,0 \\
\hline kunst en cultuur & 32,9 & 33,1 \\
\hline Totaal & 36,6 & 36,9 \\
\hline \multicolumn{3}{|l|}{ wo } \\
\hline landbouw & 37,0 & 37,1 \\
\hline techniek & 38,4 & 39,1 \\
\hline economie & 38,7 & 39,1 \\
\hline gezondheidszorg & 37,7 & 39,0 \\
\hline gedrag en maatschappij & 36,4 & 36,0 \\
\hline taal en cultuur & 38,3 & 36,0 \\
\hline recht en openbare orde & 38,0 & 38,7 \\
\hline natuurwetenschappen & 47,2 & 38,2 \\
\hline Totaal & 38,7 & 37,9 \\
\hline Totaal & 37,4 & 36,4 \\
\hline
\end{tabular}

$-=$ te weinig waarnemingen

\section{Toelichting}

De gewenste wekelijkse arbeidsduur is bepaald op basis van de vraag in de enquête: Als u zelf zou mogen kiezen, hoeveel uren per week zou u dan het liefst betaald werk willen hebben? De feitelijke wekelijkse arbeidsduur betreft zowel het aantal uren in de hoofdfunctie als het aantal uren in eventuele nevenfuncties. 
Tabel A3.12

Oordeel van de werkende schoolverlaters over de aansluiting tussen de afgesloten opleiding en de huidige functie

\begin{tabular}{|c|c|c|c|c|}
\hline Opleidingssector & $\underset{\%}{\text { goed }}$ & $\begin{array}{l}\text { voldoende } \\
\%\end{array}$ & $\underset{\%}{\operatorname{matig}}$ & $\begin{array}{c}\text { slecht } \\
\%\end{array}$ \\
\hline \multicolumn{5}{|l|}{ BOL niv. 1/2 } \\
\hline oriënteren en schakelen & 35 & 32 & 16 & 16 \\
\hline landbouw & 45 & 24 & 6 & 26 \\
\hline techniek & 39 & 32 & 18 & 11 \\
\hline economie & 43 & 34 & 9 & 14 \\
\hline gezondheidszorg & 46 & 21 & 5 & 28 \\
\hline Totaal & 40 & 32 & 12 & 15 \\
\hline \multicolumn{5}{|l|}{ BOL niv. $3 / 4$} \\
\hline landbouw & 41 & 34 & 12 & 12 \\
\hline techniek & 39 & 38 & 15 & 7 \\
\hline economie & 38 & 41 & 13 & 7 \\
\hline gezondheidszorg & 54 & 30 & 9 & 7 \\
\hline gedrag en maatschappij & 43 & 32 & 11 & 13 \\
\hline Totaal & 42 & 37 & 12 & 9 \\
\hline \multicolumn{5}{|l|}{ HBO } \\
\hline landbouw & 41 & 40 & 13 & 7 \\
\hline onderwijs & 53 & 33 & 10 & 5 \\
\hline techniek & 45 & 41 & 12 & 3 \\
\hline economie & 43 & 41 & 12 & 4 \\
\hline gezondheidszorg & 54 & 34 & 9 & 3 \\
\hline gedrag en maatschappij & 43 & 39 & 13 & 5 \\
\hline kunst en cultuur & 39 & 30 & 14 & 17 \\
\hline Totaal & 46 & 38 & 12 & 5 \\
\hline \multicolumn{5}{|l|}{ wo } \\
\hline landbouw & 45 & 39 & 10 & 7 \\
\hline techniek & 51 & 35 & 10 & 3 \\
\hline economie & 53 & 36 & 8 & 2 \\
\hline gezondheidszorg & 68 & 21 & 8 & 3 \\
\hline gedrag en maatschappij & 36 & 33 & 20 & 10 \\
\hline taal en cultuur & 29 & 31 & 21 & 19 \\
\hline recht en openbare orde & 50 & 35 & 10 & 6 \\
\hline natuurwetenschappen & 57 & 29 & 9 & 5 \\
\hline Totaal & 50 & 33 & 11 & 5 \\
\hline Totaal & 44 & 36 & 12 & 8 \\
\hline
\end{tabular}

Toelichting

- Vraag in de enquête: Hoe vindt $u$ de aansluiting tussen uw [...] opleiding en uw huidige functie?

- Voor het WO hebben de resultaten betrekking op 9 universiteiten. 
Tabel A3.13

Percentage werkende schoolverlaters dat op zoek is naar een andere baan

Opleidingssector $\%$

AVO

MAVO

HAVO

VWO

Totaal

VBO

IVBO

landbouw

techniek

economie

gezondheidszorg

Totaal

BOL niv. 1/2

oriënteren en schakelen

landbouw

techniek

economie

gezondheidszorg

Totaal

\section{0}

$-$

BOL niv. $3 / 4$

landbouw

techniek

economie

gezondheidszorg

gedrag en maatschappij

Totaal

HBO

landbouw

onderwijs

techniek

economie

gezondheidszorg

gedrag en maatschappij

kunst en cultuur

\section{6}

40

Totaal

wo

landbouw

techniek

economie

gezondheidszorg

gedrag en maatschappij

taal en cultuur

recht en openbare orde

natuurwetenschappen

Totaal

Totaal

- = te weinig waarnemingen

\section{Toelichting}

Vraag in de enquête: Heeft $u$ in de afgelopen vier weken iets gedaan om aan ander werk te komen? 
Tabel A3.14

Deelname aan een cursus of bedrijfsopleiding door werkende schoolverlaters

Opleidingssector

BOL niv. $1 / 2$

oriënteren en schakelen 38

landbouw 13

techniek 40

\begin{tabular}{ll} 
economie & 27 \\
\hline & 187
\end{tabular}

gezondheidszorg 18

BOL niv. $3 / 4$

landbouw

techniek

economie

gezondheidszorg

gedrag en maatschappij

Totaal

\section{HBO}

landbouw

onderwijs

techniek

economie

gezondheidszorg

gedrag en maatschappij

kunst en cultuur

Totaal

wo

landbouw

techniek

economie

gezondheidszorg

gedrag en maatschappi

taal en cultuur

recht en openbare orde

natuurwetenschappen

Totaal

Totaal

Toelichting

- Vraag in de enquête: Heeft u na het verlaten van de [...] opleiding een cursus of bedrijfsopleiding gevolgd? - Voor het WO hebben de resultaten betrekking op 9 universiteiten. 
Tabel A3.15

Belangrijkste cursussen of bedrijfsopleidingen waaraan werkende schoolverlaters deelnemen

$\%$

BOL niv. 1/2 oriënteren en schakelen

Techniek

Weg-, railvervoer

Secretarieel (incl. tekstverwerking, steno)

Detailhandel (incl. middenstandsdiploma)

Horeca

Communicatieve vaardigheden

Nederlands

Politie

Wiskunde

BOL niv 1/2 landbouw

$\mathrm{BB}$, bedrijfszelfbescherming

Metaalbewerking

Ladingbehandeling

Commercieel

BOL niv. 1/2 techniek

Bedrijfstechniek, technische bedrijfsvoering

Techniek

Telecommunicatie/datacommunicatie

Elektrische energietechniek

Bouwkunde

Ladingbehandeling

Brandweer

Politie

Detailhandel (incl. middenstandsdiploma)

BOL niv. 1/2 economie

Computer en informatica

Detailhandel (incl. middenstandsdiploma)

Bedrijfsadministratie, accountancy

Commercieel

Secretarieel (incl. tekstverwerking, steno)

Bedrijfstechniek, technische bedrijfsvoering

BOL niv. 1/2 gezondheidszorg

Horeca

Detailhandel (incl. middenstandsdiploma)

Communicatieve vaardigheden

Uiterlijke verzorging

Gezondheidszorg

Maatschappelijk werk

Zeemacht

BOL niv. 3/4 landbouw

Bedrijfstechniek, technische bedrijfsvoering

Veeteelt

Weg-, railvervoer

Bedrijfskunde, management, efficiency

Landbouw

BOL niv. 3/4 techniek

Computer en informatica

Bedrijfstechniek, technische bedrijfsvoering

Techniek

Elektrotechniek

Werktuigbouwkunde

Bedrijfskunde, management, efficiency 
Tabel A3.15 (vervolg)

Belangrijkste cursussen of bedrijfsopleidingen waaraan werkende schoolverlaters deelnemen

$\%$

BOL niv. 3/4 economie

Verzekeringswezen

Geld- en bankzaken

Computer en informatica

Bedrijfsadministratie, accountancy

Commercieel

Detailhandel (incl. middenstandsdiploma)

Bedrijfskunde, management, efficiency

Secretarieel (incl. tekstverwerking, steno)

Marketing, reclame

BOL niv. 3/4 gezondheidszorg

Farmacie

Uiterlijke verzorging

Detailhandel (incl. middenstandsdiploma)

Gezondheidszorg

Verpleging

BOL niv. 3/4 gedrag en maatschappij

Gezondheidszorg

Communicatieve vaardigheden

Bedrijfskunde, management, efficiency

Computer en informatica

Maatschappelijk werk

HBO landbouw

Computer en informatica

Bedrijfskunde, management, efficiency

Commercieel

Bedrijfstechniek, technische bedrijfsvoering

Bedrijfsadministratie, accountancy

HBO onderwijs

Basisonderwijs/onderwijzers (incl. remedial teacher)

Computer en informatica

Pedagog.-didactische cursussen voor leer

Gezondheidszorg

HBO techniek

Computer en informatica

Bedrijfskunde, management, efficiency

Bedrijfstechniek, technische bedrijfsvoering

Telecommunicatie/datacommunicatie

\section{HBO economie}

Geld- en bankzaken

Computer en informatica

Bedrijfsadministratie, accountancy

Bedrijfskunde, management, efficiency

Commercieel

Marketing, reclame

Verzekeringswezen

HBO gezondheidszorg

Fysiotherapie, bewegingsleer

Verpleging

Gezondheidszorg

Geneeskunde

Therapie

Logo-/akoepedie, orthopedie

Arbeids-/ergotherapie 
Tabel A3.15 (vervolg)

Belangrijkste cursussen of bedrijfsopleidingen waaraan werkende schoolverlaters deelnemen

$\%$

HBO gedrag en maatschappij

Maatschappelijk werk

Computer en informatica

Commercieel

Personeelswerk

Recht

Bedrijfskunde, management, efficiency

Marketing, reclame

HBO kunst en cultuur

Computer en informatica

Muziek

Bedrijfskunde, management, efficiency

Kunst en cultuur

Detailhandel (incl. middenstandsdiploma)

\section{WO landbouw}

Computer en informatica

Bedrijfskunde, management, efficiency

Communicatieve vaardigheden

Marketing, reclame

WO techniek

Computer en informatica

Bedrijfskunde, management, efficiency

Communicatieve vaardigheden

Techniek

Persoonlijke ontplooiing

WO economie

Computer en informatica

Geld- en bankzaken

Bedrijfskunde, management, efficiency

Communicatieve vaardigheden

Belastingen

Commercieel

WO gezondheidszorg

Gezondheidszorg

Geneeskunde

Computer en informatica

Bedrijfskunde, management, efficiency

Sociaal werk

Verpleging

WO gedrag en maatschappij

Computer en informatica

Bedrijfskunde, management, efficiency

Communicatieve vaardigheden

Marketing, reclame

Personeelswerk

Geld- en bankzaken

Recht

WO taal en cultuur

Computer en informatica

Marketing, reclame

Bedrijfskunde, management, efficiency

Commercieel

Communicatieve vaardigheden 
Tabel A3.15 (vervolg)

Belangrijkste cursussen of bedrijfsopleidingen waaraan werkende schoolverlaters deelnemen

\section{$\%$}

WO recht en openbare orde

Recht

34

Belastingen

Geld- en bankzaken

Verzekeringswezen

13

9

WO natuurwetenschappen

Computer en informatica

Bedrijfskunde, management, efficiency

Communicatieve vaardigheden

Techniek

Toelichting

- In de tabel zijn alleen die cursussen en bedrijfsopleidingen opgenomen waaraan ten minste $5 \%$ van de schoolverlaters deelneemt.

- Voor het WO hebben de resultaten betrekking op 9 universiteiten. 


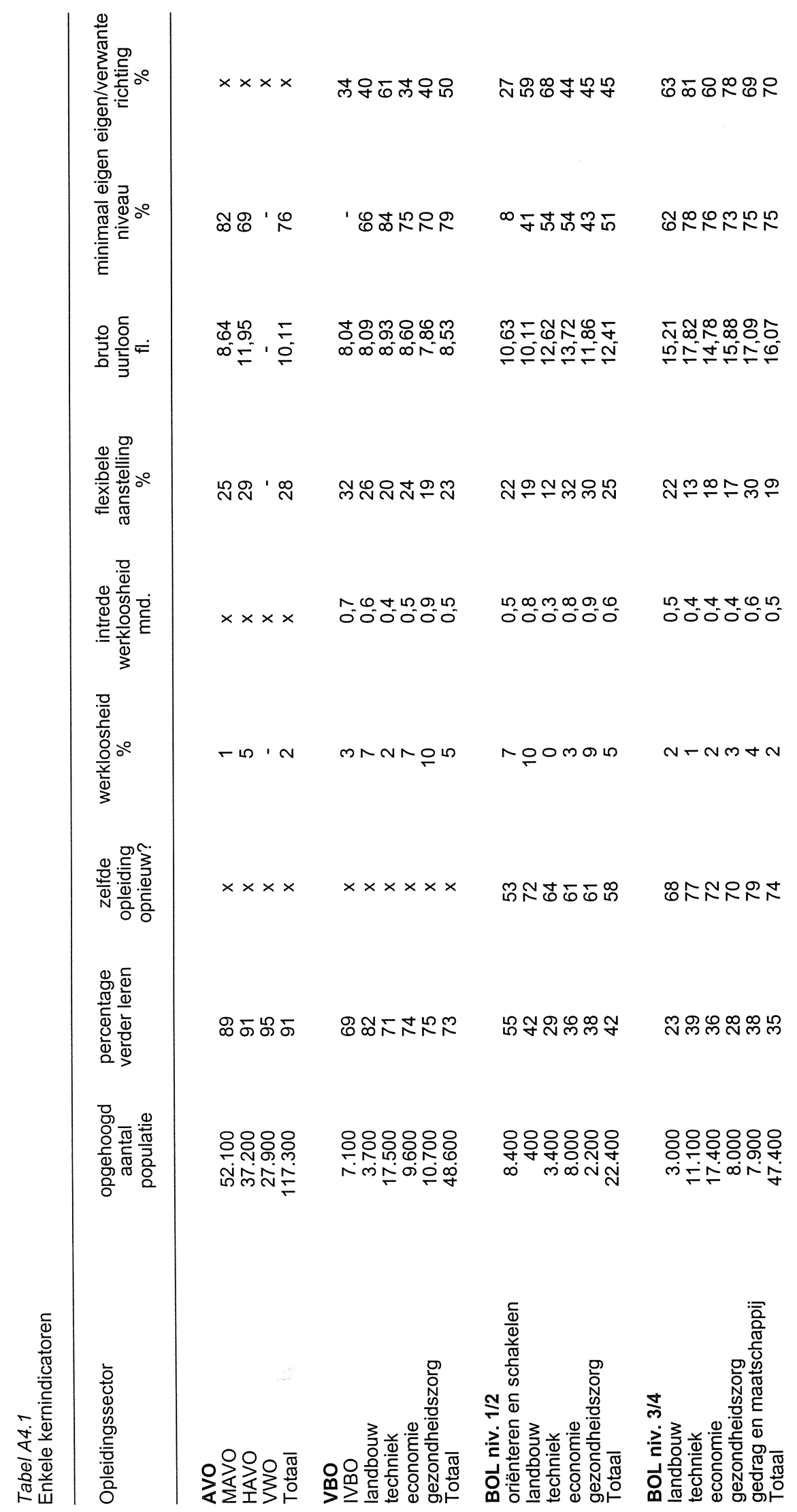




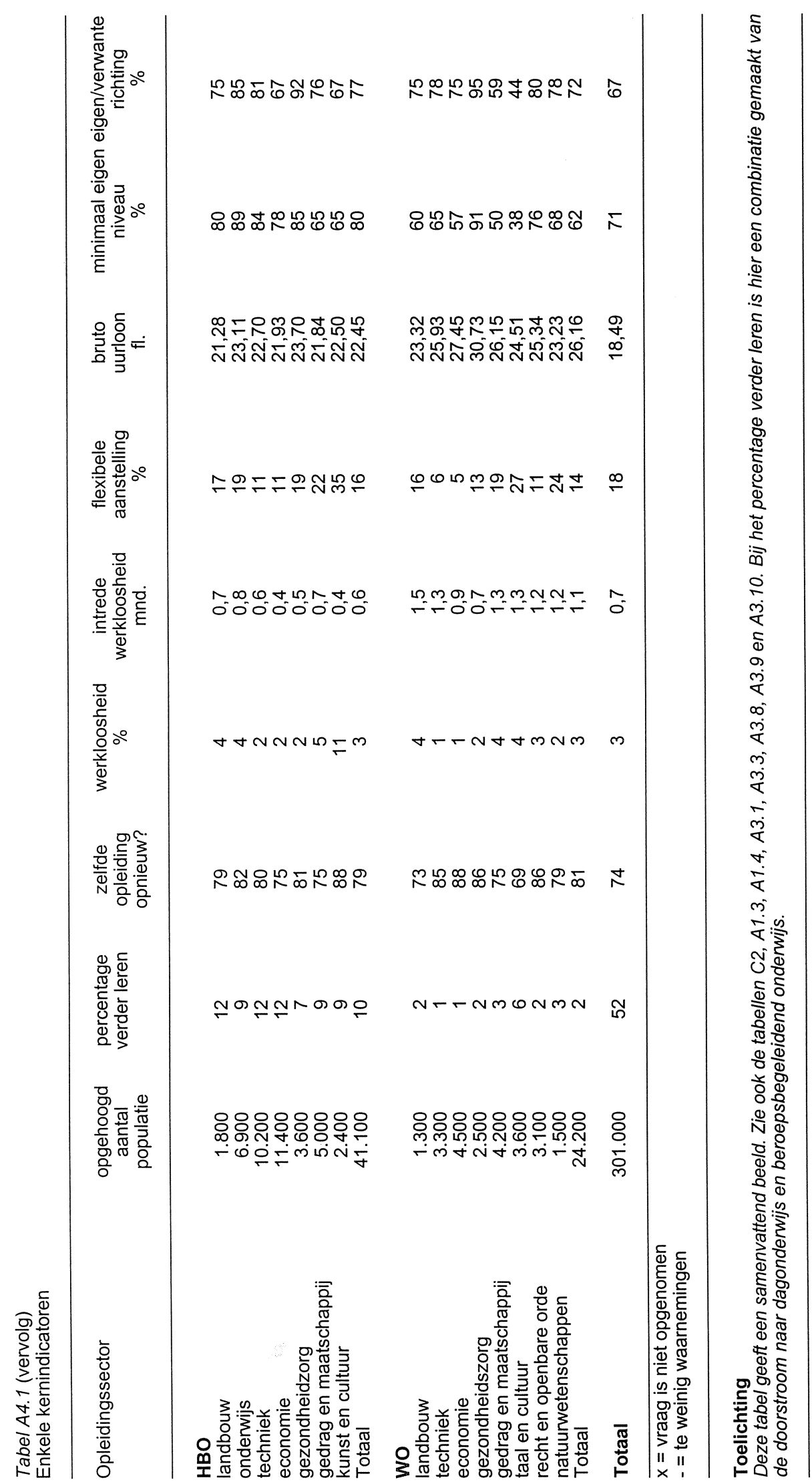


B. Tabellen per opleidingsrichting 
Tabel B1.1

De uitstroom van schoolverlaters verbijzonderd naar geslacht, etniciteit en gemiddelde leeftijd op moment van enquête

\begin{tabular}{lccc}
\hline Opleidingsrichting & vrouw & $\begin{array}{c}\text { alloch- } \\
\text { toon } \\
\%\end{array}$ & $\begin{array}{c}\text { gem. } \\
\%\end{array}$
\end{tabular}

VBO

IVBO Landbouw en natuurlijke omgeving

IVBO Bouwtechniek

IVBO Mechanische techniek

IVBO Verzorging

Landbouw en natuurlijke omgeving

Bouwtechniek

Mechanische techniek

Elektrotechniek

Motorvoertuigentechniek

Consumptieve techniek

Administratie

Verkoop

Handel

Verzorging

Uiterlijke verzorging

Mode en kleding

BOL niv. 1/2

Oriënteren en schakelen

niv. 2 Bloemschikken

Houtbewerking en woninginrichting

Werktuigbouwkunde

Motorvoertuigen en carrosserietechniek

Energie- en informatietechniek

Brood- en banketbakken

Bedrijfsadministratie

Beveiliging

Secretarieel

Detailhandel/ambulante handel

Horeca, instellingskeuken en contractcatering

Facilitaire dienstverlening

Verpleging en verzorging

niv. $3 / 4$

niv. 3 Plantenteelt

niv. 3 Veehouderij

niv. 3 Bloemschikken

niv. 3 Groene ruimte

niv. 4 Plantenteelt

niv. 4 Veehouderij

niv. 4 Levensmiddelentechnologie

niv. 4 Bloemschikken

niv. 4 Dierenverzorging en veterinaire ondersteuning

niv. 4 Groene ruimte

Bouw

Houtbewerking en woninginrichting

Grond-, water- en wegenbouw

Fijnmechanische techniek

Werktuigbouwkunde

Motorvoertuigen en carrosserietechniek

Energie- en informatietechniek

Energietechniek

Informatietechniek

Mode en kleding (realisatie)

Laboratoriumtechniek

Procestechniek

Transport \& logistiek

Bedrijfsadministratie

Commerciële dienstverlening 
Tabel B1.1 (vervolg)

De uitstroom van schoolverlaters verbijzonderd naar geslacht, etniciteit en gemiddelde leeftijd op moment van enquête

\begin{tabular}{lccc}
\hline Opleidingsrichting & vrouw & $\begin{array}{c}\text { alloch- } \\
\text { toon } \\
\%\end{array}$ & $\begin{array}{c}\text { gem. } \\
\text { leeftijd }\end{array}$ \\
\hline Economisch-juridisch & $\%$ & 17 & 21,6 \\
Secretarieel & 37 & 6 & 21,5 \\
Detailhandel/ambulante handel & 99 & 5 & 21,2 \\
Groothandel/distributie & 35 & 5 & 21,3 \\
Horeca, instellingskeuken en contractcatering & 48 & 1 & 22,7 \\
Toerisme, recreatie en reizen & 52 & 1 & 22,1 \\
Assistenten gezondheidszorg & 89 & 9 & 21,3 \\
Facilitaire dienstverlening & 99 & 1 & 21,2 \\
Sport en bewegen & 69 & 2 & 22,3 \\
Verpleging en verzorging & 29 & 2 & 21,5 \\
Uiterlijke verzorging & 94 & 11 & 21,1 \\
Sociaal-cultureel werker & 98 & 2 & 24,3 \\
Sociaal-pedagogisch werker & 93 & 21 & 22,2 \\
Sociaal-juridische dienstverlening & 91 & & 21,7 \\
\end{tabular}

Zie ook toelichting bladzijde 3 . 
Tabel B1.2

Hoogste in het voortgezet onderwijs behaalde diploma

\begin{tabular}{|c|c|c|c|c|c|c|c|}
\hline Opleidingsrichting & MAVO & HAVO & VWO & VBO & $\begin{array}{c}\text { BOL } \\
\text { niv. } \\
1 / 2 \\
\%\end{array}$ & $\begin{array}{c}\text { BOL } \\
\text { niv. } \\
3 / 4 \\
\%\end{array}$ & $\begin{array}{c}\text { overig } \\
\%\end{array}$ \\
\hline
\end{tabular}

BOL niv. 1/2

Oriënteren en schakelen

niv. 2 Bloemschikken

Houtbewerking en woninginrichting

Werktuigbouwkunde

Motorvoertuigen en carrosserietechniek

Energie- en informatietechniek

Brood- en banketbakken

Bedrijfsadministratie

Beveiliging

Secretarieel

Detailhandel/ambulante hande

Horeca, instellingskeuken en contractcatering

Facilitaire dienstverlening

Verpleging en verzorging

$\begin{array}{rrrrrrr}37 & 9 & 1 & 41 & 1 & 4 & 7 \\ 5 & 0 & 0 & 90 & 0 & 0 & 5 \\ 23 & 0 & 0 & 59 & 14 & 5 & 0 \\ 22 & 0 & 0 & 66 & 11 & 0 & 0 \\ 21 & 0 & 0 & 64 & 14 & 0 & 0 \\ 24 & 0 & 0 & 67 & 6 & 0 & 2 \\ 21 & 2 & 0 & 76 & 0 & 1 & 0 \\ 43 & 1 & 0 & 47 & 6 & 2 & 2 \\ 64 & 0 & 0 & 13 & 0 & 6 & 17 \\ 35 & 1 & 1 & 55 & 5 & 1 & 2 \\ 30 & 1 & 0 & 60 & 7 & 0 & 2 \\ 39 & 1 & 0 & 51 & 3 & 6 & 0 \\ 18 & 4 & 0 & 65 & 4 & 4 & 4 \\ 7 & 0 & 1 & 82 & 2 & 3 & 6\end{array}$

BOL niv. $3 / 4$

niv. 3 Plantenteelt

niv. 3 Veehouderij

niv. 3 Bloemschikken

niv. 3 Groene ruimte

niv. 4 Plantenteelt

niv. 4 Veehouderi

niv. 4 Levensmiddelentechnologie

niv. 4 Bloemschikken

niv. 4 Dierenverzorging

niv. 4 Groene ruimte

Bouw

Houtbewerking en woninginrichting

Grond-, water- en wegenbouw

Fijnmechanische techniek

Werktuigbouwkunde

Motorvoertuigen en carrosserietechniek

Energie- en informatietechniek

Energietechniek

Informatietechniek

Mode en kleding (realisatie)

Laboratoriumtechniek

Procestechniek

Transport \& logistiek

Bedrijfsadministratie

Commerciële dienstverlening

Economisch-juridisch

Secretarieel

Detailhandel/ambulante handel

Groothandel/distributie

Horeca, instellingskeuken en contractcatering

Toerisme, recreatie en reizen

Assistenten gezondheidszorg

Facilitaire dienstverlening

Sport en bewegen

Verpleging en verzorging

Uiterlijke verzorging

Sociaal-cultureel werker

Sociaal-pedagogisch werke

Sociaal-juridische dienstverlening

$\begin{array}{lr}22 & 3 \\ 20 & \\ 22 & \\ 31 & \\ 58 & 12 \\ 55 & 7 \\ 59 & 16 \\ 48 & 14 \\ 42 & 42 \\ 44 & 30 \\ 60 & 13 \\ 44 & 26 \\ 68 & 15 \\ 51 & \\ 54 & 14 \\ 51 & 13 \\ 53 & \\ 47 & \\ 39 & 17 \\ 49 & 20 \\ 77 & 15 \\ 59 & 17 \\ 69 & 12 \\ 53 & 27 \\ 63 & 23 \\ 79 & 8 \\ 52 & 29 \\ 61 & 10 \\ 59 & 30 \\ 50 & 37 \\ 58 & 38 \\ 71 & 14 \\ 80 & \\ 73 & 17 \\ 55 & \\ 58 & 14 \\ 54 & \\ 64 & \\ 61 & \end{array}$


Tabel B1.3

Bestemming van schoolverlaters

\begin{tabular}{|c|c|c|c|c|c|}
\hline Opleidingsrichting & $\begin{array}{c}\text { studie } \\
\%\end{array}$ & $\begin{array}{c}\text { BBL } \\
\%\end{array}$ & $\begin{array}{c}\text { betaald } \\
\text { werk } \\
\%\end{array}$ & $\begin{array}{c}\text { werkloos } \\
\%\end{array}$ & $\begin{array}{c}\text { anders } \\
\%\end{array}$ \\
\hline
\end{tabular}

VBO

IVBO Landbouw en natuurlijke omgeving

IVBO Bouwtechniek

IVBO Mechanische techniek

IVBO Verzorging

Landbouw en natuurlijke omgeving

Bouwtechniek

Mechanische techniek

Elektrotechniek

Motorvoertuigentechniek

Consumptieve techniek

Administratie

Verkoop

Handel

Verzorging

Uiterlijke verzorging

Mode en kleding

$\begin{array}{rr}42 & 21 \\ 20 & 46 \\ 22 & 33 \\ 64 & 9 \\ 67 & 15 \\ 26 & 37 \\ 53 & 23 \\ 63 & 17 \\ 40 & 31 \\ 36 & 29 \\ 68 & 9 \\ 69 & 8 \\ 52 & 5 \\ 66 & 10 \\ 37 & 29 \\ 64 & 12\end{array}$

$\begin{array}{lll}31 & 2 & 3 \\ 33 & 0 & 0 \\ 44 & 0 & 0 \\ 23 & 0 & 5 \\ 15 & 1 & 3 \\ 35 & 1 & 1 \\ 21 & 2 & 2 \\ 18 & 1 & 2 \\ 29 & 0 & 0 \\ 33 & 0 & 2 \\ 21 & 0 & 2 \\ 19 & 2 & 2 \\ 41 & 2 & 0 \\ 20 & 1 & 3 \\ 24 & 3 & 8 \\ 20 & 0 & 4\end{array}$

BOL niv. 1/2

Oriënteren en schakelen

niv. 2 Bloemschikken

Houtbewerking en woninginrichting

Werktuigbouwkunde

Motorvoertuigen en carrosserietechniek

Energie- en informatietechniek

Brood-en banketbakken

Bedrijfsadministratie

Beveiliging

Secretariee

Detailhandel/ambulante handel

Horeca, instellingskeuken en contractcatering

Facilitaire dienstverlening

Verpleging en verzorging

$\begin{array}{rrrrr}52 & 3 & 38 & 4 & 3 \\ 12 & 20 & 56 & 8 & 4 \\ 32 & 5 & 59 & 5 & 0 \\ 24 & 3 & 70 & 3 & 0 \\ 0 & 20 & 73 & 0 & 7 \\ 12 & 16 & 69 & 0 & 4 \\ 12 & 18 & 70 & 0 & 0 \\ 30 & 2 & 65 & 1 & 3 \\ 11 & 0 & 83 & 6 & 0 \\ 40 & 1 & 56 & 1 & 1 \\ 32 & 5 & 56 & 4 & 3 \\ 16 & 31 & 50 & 2 & 1 \\ 15 & 3 & 74 & 8 & 0 \\ 38 & 9 & 48 & 1 & 4\end{array}$

BOL niv. $3 / 4$

niv. 3 Plantenteelt

niv. 3 Veehouderij

niv. 3 Bloemschikken

niv. 3 Groene ruimte

niv. 4 Plantenteelt

niv. 4 Veehouderij

niv. 4 Levensmiddelentechnologie

niv. 4 Bloemschikken

niv. 4 Dierenverzorging en veterinaire

ondersteuning

niv. 4 Groene ruimte

Bouw

Houtbewerking en woninginrichting

Grond-, water- en wegenbouw

Fijnmechanische techniek

Werktuigbouwkunde

Motorvoertuigen en carrosserietechniek

Energie- en informatietechniek

Energietechniek

Informatietechniek

Mode en kleding (realisatie)

Laboratoriumtechniek

Procestechniek

Transport \& logistiek

Bedrijfsadministratie

Commerciële dienstverlening 
Tabel B1.3 (vervolg)

Bestemming van schoolverlaters

\begin{tabular}{|c|c|c|c|c|c|}
\hline Opleidingsrichting & $\begin{array}{c}\text { studie } \\
\%\end{array}$ & $\begin{array}{c}\text { BBL } \\
\%\end{array}$ & $\begin{array}{c}\text { betaald } \\
\text { werk } \\
\%\end{array}$ & $\begin{array}{c}\text { werkloos } \\
\%\end{array}$ & $\begin{array}{c}\text { anders } \\
\%\end{array}$ \\
\hline $\begin{array}{l}\text { Economisch-juridisch } \\
\text { Secretarieel } \\
\text { Detailhandel/ambulante handel } \\
\text { Groothandel/distributie } \\
\text { Horeca, instellingskeuken en contractcatering } \\
\text { Toerisme, recreatie en reizen } \\
\text { Assistenten gezondheidszorg } \\
\text { Facilitaire dienstverlening } \\
\text { Sport en bewegen } \\
\text { Verpleging en verzorging } \\
\text { Uiterlijke verzorging } \\
\text { Sociaal-cultureel werker } \\
\text { Sociaal-pedagogisch werker } \\
\text { Sociaal-juridische dienstverlening }\end{array}$ & $\begin{array}{l}27 \\
21 \\
32 \\
47 \\
23 \\
26 \\
13 \\
40 \\
34 \\
26 \\
15 \\
30 \\
36 \\
44\end{array}$ & $\begin{array}{l}2 \\
0 \\
3 \\
1 \\
1 \\
0 \\
1 \\
4 \\
2 \\
7 \\
0 \\
1 \\
3 \\
1\end{array}$ & $\begin{array}{l}67 \\
77 \\
63 \\
50 \\
74 \\
71 \\
84 \\
52 \\
62 \\
64 \\
80 \\
62 \\
57 \\
51\end{array}$ & $\begin{array}{l}3 \\
0 \\
1 \\
2 \\
1 \\
2 \\
1 \\
5 \\
2 \\
1 \\
2 \\
3 \\
1 \\
3\end{array}$ & $\begin{array}{l}1 \\
1 \\
1 \\
0 \\
1 \\
0 \\
1 \\
0 \\
1 \\
2 \\
2 \\
4 \\
3 \\
2\end{array}$ \\
\hline
\end{tabular}


Tabel B1.4

Gevolgde opleiding opnieuw kiezen?

\begin{tabular}{|c|c|c|c|}
\hline & $\begin{array}{l}\text { zelfde } \\
\text { oleiding }\end{array}$ & $\begin{array}{l}\text { andere } \\
\text { opleiding }\end{array}$ & $\begin{array}{l}\text { geen } \\
\text { opleiding }\end{array}$ \\
\hline \multicolumn{4}{|l|}{ BOL niv. $1 / 2$} \\
\hline Orienteren en schakelen & 53 & 32 & 15 \\
\hline niv. 2 Bloemschikken & 56 & 44 & 0 \\
\hline Houtbewerking en woninginrichting & 78 & 17 & 4 \\
\hline Werktuigbouwkunde & 81 & 19 & 0 \\
\hline Motorvoertuigen en carrosserietechniek & 60 & 27 & 13 \\
\hline Energie- en informatietechniek & 53 & 39 & 8 \\
\hline Brood- en banketbakken & 74 & 20 & 6 \\
\hline Bedrijfsadministratie & 60 & 33 & 7 \\
\hline Beveiliging & 83 & 17 & 0 \\
\hline Secretariaat & 75 & 24 & 1 \\
\hline Detailhandel/ambulante handel & 56 & 36 & 8 \\
\hline Horeca, instellingskeuken en & 64 & 34 & 2 \\
\hline Facilitaire dienstverlening & 39 & 61 & 0 \\
\hline Verpleging en verzorging & 65 & 32 & 3 \\
\hline \multicolumn{4}{|l|}{ BOL niv. $3 / 4$} \\
\hline niv. 3 Plantenteelt & 72 & 28 & 0 \\
\hline niv. 3 Veehouderij & 58 & 31 & 10 \\
\hline niv. 3 Bloemschikken & 52 & 40 & 9 \\
\hline niv. 3 Groene ruimte & 71 & 29 & 0 \\
\hline niv. 4 Plantenteelt & 76 & 23 & 2 \\
\hline niv. 4 Veehouderij & 74 & 25 & $\overline{1}$ \\
\hline niv. 4 Levensmiddelentechnologie & 62 & 38 & 0 \\
\hline niv. 4 Bloemschikken & 67 & 33 & 0 \\
\hline \multicolumn{4}{|l|}{ niv. 4 Dierenverzorging en veterinaire } \\
\hline ondersteuning & 63 & 37 & 0 \\
\hline niv. 4 Groene ruimte & 77 & 23 & 0 \\
\hline Bouw & 76 & 23 & 1 \\
\hline Houtbewerking en woninginrichting & 85 & 15 & 0 \\
\hline Grond-, water- en wegenbouw & 80 & 14 & 6 \\
\hline Fijnmechanische techniek & 69 & 31 & 0 \\
\hline Werktuigbouwkunde & 76 & 24 & 0 \\
\hline Motorvoertuigen en carrosserietechniek & 78 & 20 & 1 \\
\hline Energie- en informatietechniek & 78 & 20 & 1 \\
\hline Energietechniek & 85 & 15 & 0 \\
\hline Informatietechniek & 87 & 13 & 0 \\
\hline Mode en kleding (realisatie) & 58 & 40 & 1 \\
\hline Laboratoriumtechniek & 76 & 23 & 1 \\
\hline Procestechniek & 82 & 18 & 0 \\
\hline Transport \& logistiek & 76 & 24 & 0 \\
\hline Bedrijfsadminstratie & 78 & 20 & 1 \\
\hline Commerciële dienstverlening & 72 & 27 & 1 \\
\hline Economisch-juridisch & 59 & 38 & 3 \\
\hline Secretarieel & 70 & 29 & 1 \\
\hline Detailhandel/ambulante handel & 65 & 33 & 2 \\
\hline Groothandel/distributie & 77 & 22 & 1 \\
\hline \multicolumn{4}{|l|}{ Horeca, instellingskeuken en } \\
\hline contractcatering & 75 & 23 & 1 \\
\hline Toerisme, recreatie en reizen & 69 & 30 & 1 \\
\hline Assistenten gezondheidszorg & 78 & 21 & 1 \\
\hline $\begin{array}{l}\text { Facilitaire dienstverlening } \\
\text { a }\end{array}$ & 49 & 48 & 3 \\
\hline Sport en bewegen & 89 & 11 & 0 \\
\hline Verpleging en verzorging & 71 & 27 & 1 \\
\hline Uiterlijke verzorging & 57 & 42 & 1 \\
\hline Sociaal-cultureel werker & 70 & 30 & 0 \\
\hline Sociaal-pedagogisch werker & 80 & 20 & 0 \\
\hline Sociaal-juridische dienstverlening & 75 & 25 & 0 \\
\hline
\end{tabular}




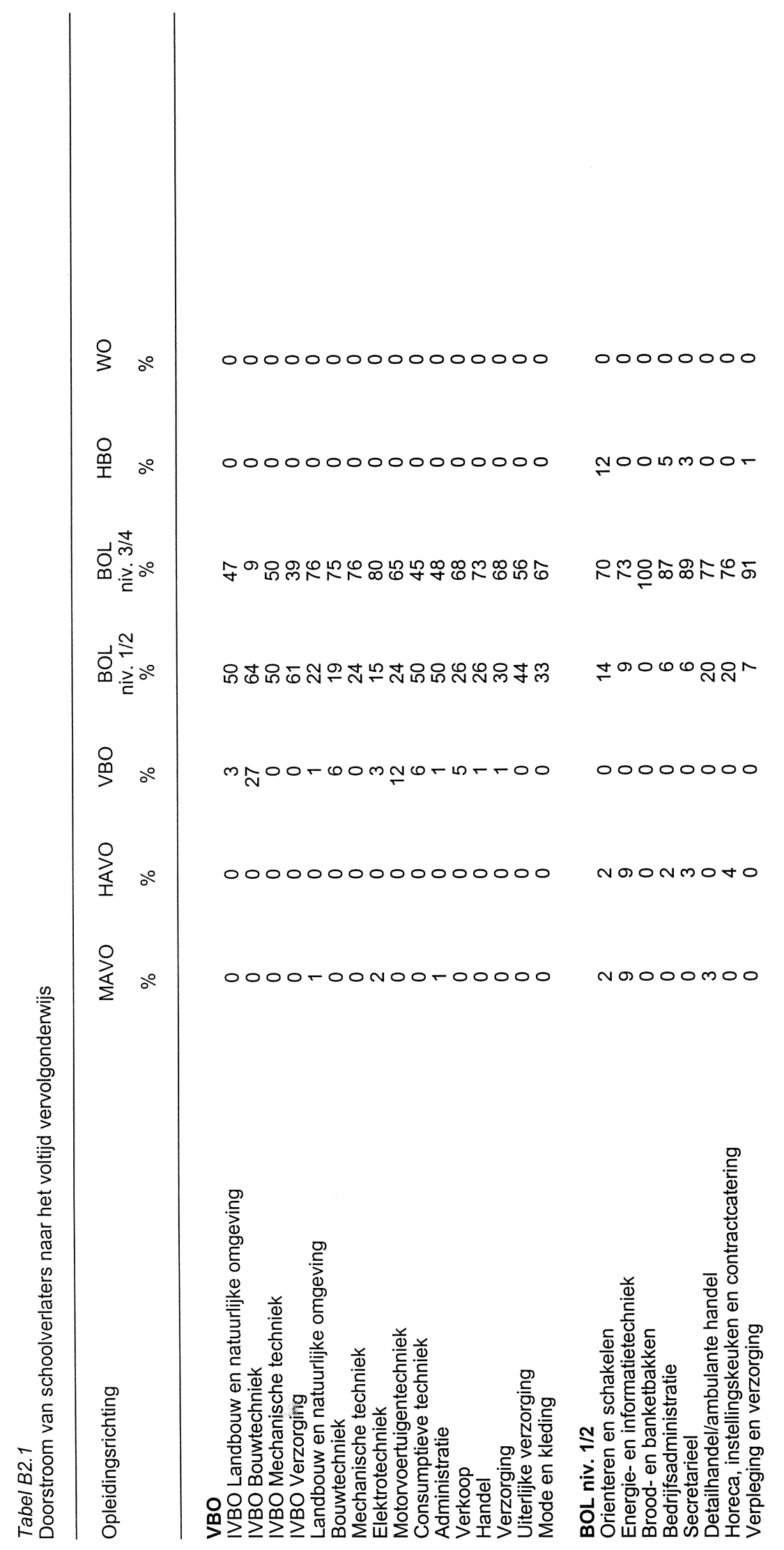




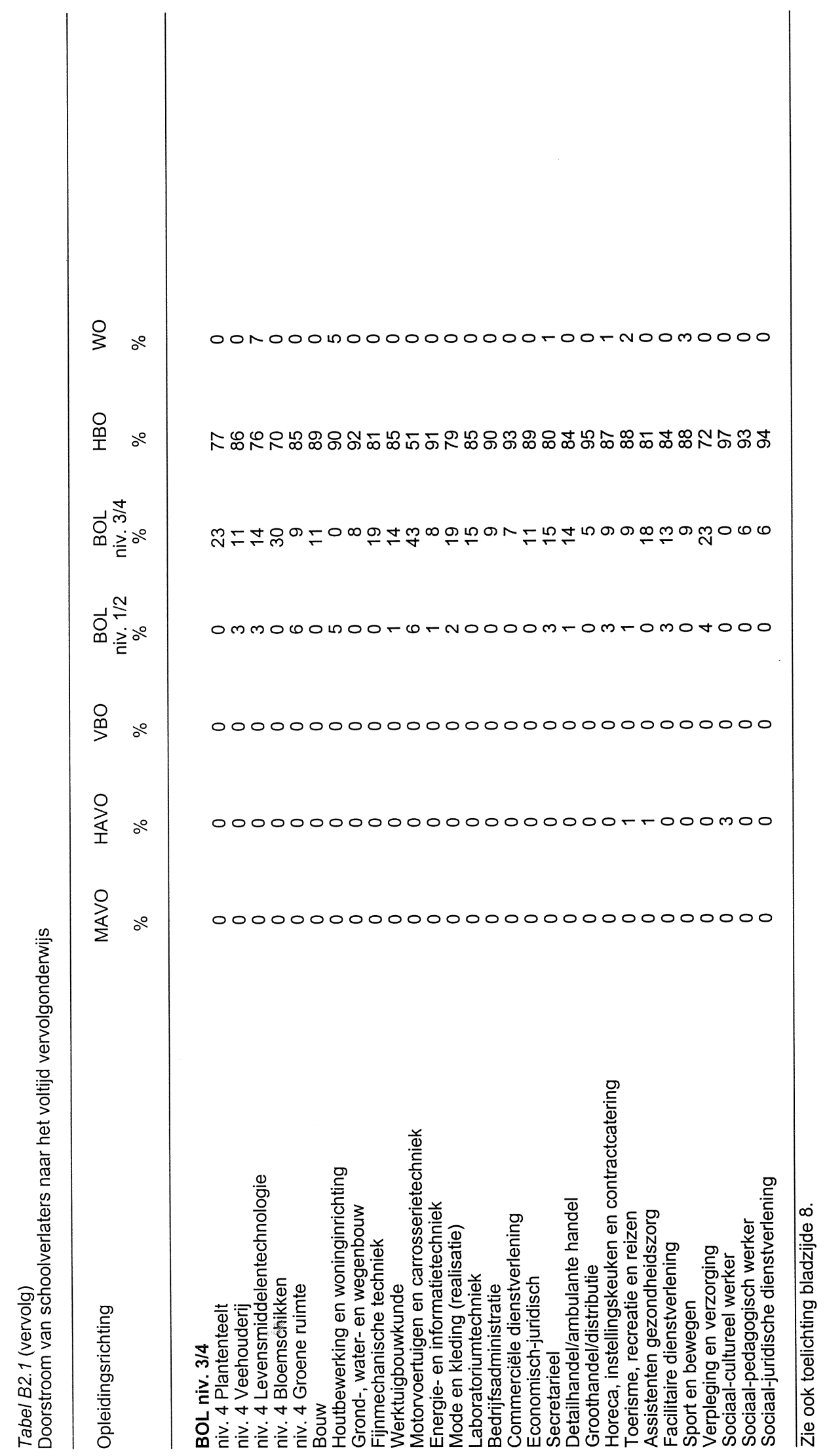


Tabel B2.2

Belangrijkste opleidingen van schoolverlaters die een voltijd vervolgopleiding zijn gaan volgen

IVBO Landbouw en natuurlijke omgeving

BOL BB Bloemschikken

IVBO Bouwtechniek

BBL BB Primaire timmerkracht $\quad 17$

BOL BB Primaire timmerkracht 13

BBL BB Bouw

IVBO Mechanische techniek

BOL AB Motorvoertuigen

BOL BB Chauffeur goederenvervoer

BOL BB Kok

BOL ZB Loonwerk (plantenteelt)

BOL MKF Metaalkunde

BOL MKF Scheepsbouwkundige (scheepsbouw)

BBL AB Procestechniek

BBL BB Installatie-, service- en onderhoudstechniek

BBL ZB Machinist mobiele kranen

9

9

9

9

9

9

9

IVBO Verzorging

BOL BB Helpende (verpleging en verzorging)

$B O L$ MKF Verpleging en verzorging

$B O L B B$ Verpleging en verzorging

BOL BB Facilitaire dienstverlening

BOL MKF Activiteitenbegeleider

BBL AB Detailhandel/ambulante handel

BBL ZB Leidster kindercentra

VBO Landbouw en natuurlijke omgeving

BOL KF Veehouderij

VBO Bouwtechniek

BOL MKF Bouwkunde

BBL ZB Voortgezette timmerkracht

BBL BB Schilder

VBO Mechanische techniek

BOL MKF Werktuigbouwkunde

BOL MKF Fijnmechanische techniek

VBO Elektrotechniek

BOL MKF Energie- en informatietechniek

BOL BB Energie- en informatietechniek

VBO Motorvoertuigentechniek

BOL MKF Motorvoertuigen en carrosserietechniek

BBL BB Autotechnicus/bedrijfsautotechnicus

VBO Economie

BBL BB Chauffeur goederenvervoer

$\mathrm{BBL}$ ZB Eerste autotechnicus

VBO Consumptieve techniek

BOL MKF Horeca, instellingskeuken en contractcatering

BOL BB Kok

BOL BB Brood- en banketbakken

BBL ZB Zelfstandig werkend gastheer/-vrouw 
Tabel B2.2 (vervolg)

Belangrijkste opleidingen van schoolverlaters die een voltijd vervolgopleiding zijn gaan volgen

$\%$

\section{VBO Administratie}

BOL BB Bedrijfsadministratie

BOL AB Secretarieel

BOL AB Administratief medewerker

BOL MKF Bedrijfsadministratief

BOL ZB Boekhoudkundig medewerker

10

8

VBO Verkoop

BOL MKF Detailhandel/ambulante handel

BOL BB Detailhandel/ambulante handel

11

BOL ZB Detailhandel/ambulante handel

VBO Handel

BOL MKF Internationale handel $(\mathrm{IH})$

BOL ZB Detailhandel/ambulante hande

BBL BB Horeca, instellingskeuken en contractcatering

VBO Verzorging

BOL MKF Sociaal-pedagogisch werk

BOL ZB Verzorgende

BOL BB Helpende (verpleging en verzorging)

Oriënteren en schakelen

VBO Uiterlijke verzorging

BOL ZB All-round kapper

BBL BB Kapper

BBL ZB All-round kapper

BOL BB Detailhandel/ambulante handel

VBO Mode en kleding

BOL MKF Sociaal-pedagogisch werk

BOL ZB Detailhandel/ambulante handel

Oriënteren en schakelen

BOL BB Detailhandel/ambulante handel

BOL BB Verkoopmedewerker ambulante handel

BOL BB Verkoopmedewerker

BOL BB Verpleging en verzorging

$B O L$ ZB Mode en kleding (realisatie)

BOL ZB Bedrijfsadministratief

BOL MKF Mode en kleding (realisatie)

BOL MKF Detailhandel/ambulante hande

BOL MKF Tandartsassistent

BBL BB Uitvoerend medewerker naai-/perszaal

$\mathrm{BBL}$ ZB Detailhandel/ambulante handel

BBL MKF Productie (confectie)

BOL niv. 1/2 Oriënteren en schakelen

BOL MKF Sociaal-pedagogisch werk

BOL ZB Detailhandel/ambulante handel

BOL MKF Sport en bewegen

BOL MKF Sport- en bewegingsleider

HBO Sport en bewegen

BOL niv. 1/2 Energie- en informatietechniek

BBL ZB Energie- en informatietechniek

BOL MKF Energie- en informatietechniek

BOL ZB Beheer, ontwerp en management (installatietechniek)

$\mathrm{BBL}$ ZB Eerste monteur sterkstroominstallaties 
Tabel B2.2 (vervolg)

Belangrijkste opleidingen van schoolverlaters die een voltijd vervolgopleiding zijn gaan volgen

BOL niv. 1/2 Brood- en banketbakken

BBL ZB Brood- en banketbakken

BBL MKF Brood- en banketbakken

BOL ZB Brood- en banketbakken

BOL ZB All-round banketbakker

BOL MKF Brood- en banketbakken

BBL BB Chauffeur goederenvervoer

BBL ZB All-round brood- en banketbakker

BBL Specialist Brood- en banketbakken

BOL niv. 1/2 Bedrijfsadministratie

BOL MKF Bedrijfsadministratief

BOL ZB Bedrijfsadministratief

BOL MKF Commercieel

BOL niv. $1 / 2$ Secretariee

BOL MKF Directie-secretaresse/management-assistent 19

BOL MKF Secretarieel 16

BOL ZB Secretarieel

BOL BB Medewerker reizen en toeristische informatie

BOL MKF Economie

BOL MKF Sociaal-pedagogisch werk

BOL niv. 1/2 Detailhandel/ambulante handel

BOL MKF Detailhandel/ambulante handel

BOL ZB Detailhandel/ambulante handel

BBL ZB Detailhandel/ambulante handel

BOL MKF Groothandel/distributie

BOL niv. 1/2 Horeca, instellingskeuken en contractcatering

BBL ZB Zelfstandig werkend kok

BOL MKF Horecaondernemer caf /bar en fastfood

$\mathrm{BBL}$ ZB Horeca, instellingskeuken en contractcatering

$\mathrm{BBL}$ ZB Zelfstandig werkend gastheer/-vrouw

BOL niv. 1/2 Verpleging en verzorging

BOL ZB Verzorgende

BOL MKF Sociaal-pedagogisch werk

BOL MKF Verpleging en verzorging

$\mathrm{BBL}$ ZB Verzorgende bij inst. voor gezinsverz.

$B O L$ ZB Verpleging en verzorging

BOL niv. 3/4 Plantenteelt

HBO Tuinbouw

HBO Agrarische bedrijfskunde

BOL MKF Commercieel

HBO Commerciële economie

BOL niv. 3/4 Veehouderij

HBO Agrarische bedrijfskunde

HBO Landbouw

HBO Veehouderi

HBO Landbouw

BOL niv. 3/4 Levensmiddelentechnologie

HBO Voeding en marketing

HBO Bos- en natuurbeheer

HBO Milieutechnologie (agrarische)

WO Levensmiddelentechnologie 
Tabel B2.2 (vervolg)

Belangrijkste opleidingen van schoolverlaters die een voltijd vervolgopleiding zijn gaan volgen

BOL niv. 3/4 Bloemschikken

HBO Milieukunde (agrarisch)

BOL ZB Graveur

BOL KF Bloemschikken

HBO Kort Hoger toeristisch en recreatief onderwijs

HBO Landbouw

HBO Docent plantenteelt/bloemsierkunst (2e gr.)

HBO Sociaal pedagogische hulpverlening

BOL MKF Reclame, presentatie en communicatie

BBL Specialist Bloemschikken

BOL niv. 3/4 Groene ruimte

HBO Tuin- en landschapsinrichting

HBO Bos- en natuurbeheer

BOL AB Plantenteelt

BOL KF Groenvoorziening

HBO Landbouw

HBO Milieukunde (agrarisch)

HBO Land-, water- en milieubeheer

HBO Milieutechnologie (technische)

HBO Small business en retail management

BOL niv. 3/4 Bouw

HBO Bouwkunde

BOL MKF Grond-, water- en wegenbouw

BOL niv. $3 / 4$ Houtbewerking en woninginrichting

HBO Kort Bedrijfskaderopleiding

HBO Binnenhuis

BOL AB Montagemedewerker timmerindustrie

HBO Leraar basisonderwijs

HBO Werktuigbouwkunde

HBO Industrieel product ontwerpen

HBO Technische bedrijfskunde

HBO Communicatie

HBO Culturele en maatschappelijke vorming

HBO Sociaal pedagogische hulpverlening

HBO Kunst en cultuur

HBO Architectonische vormgeving

HBO Beeldende kunst en vormgeving - vrij

WO Kunstgeschiedenis en archeologie

BOL niv. 3/4 Grond-, water- en wegenbouw HBO Civiele techniek

BOL MKF Bouwkunde

HBO Leraar basisonderwijs

HBO Geodesie

BOL niv. 3/4 Fijnmechanische techniek

HBO Werktuigbouwkunde

BBL ZB Plaatwerker

BBL ZB Tandtechnicus

HBO Technische bedrijfskunde

BOL niv. 3/4 Werktuigbouwkunde

HBO Werktuigbouwkunde

HBO Technische bedrijfskunde 
Tabel B2.2 (vervolg)

Belangrijkste opleidingen van schoolverlaters die een voltijd vervolgopleiding zijn gaan volgen

$\%$

BOL niv. 3/4 Motorvoertuigen en carrosserietechniek

BOL MKF Bedrijfsmanagement motorvoertuigen

HBO Autotechniek

BOL MKF Economie

BBL ZB Eerste autotechnicus/eerste bedrijfsautotechnicus

HBO Technische bedrijfskunde

BOL BB Economie

HBO Onderwijs

HBO Management

BOL niv. 3/4 Energie- en informatietechniek

HBO Elektrotechniek

HBO Informatica

HBO Hogere informatica

BOL niv. 3/4 Mode en kleding

HBO Leraar basisonderwijs

HBO Technisch-commerciële confectiekunde

HBO Mode-, textielvormgeving en styling

HBO Communicatie

HBO Kunst en cultuur

BOL niv. 3/4 Laboratoriumtechniek

HBO Chemie

HBO Analytische proces- en laboratoriuminstrumentatie

HBO Chemische laboratoriumopleiding

HBO Chemische technologie

HBO Medische laboratoriumopleiding

BOL niv. 3/4 Bedrijfsadministratie

HBO Bedrijfseconomie

HBO Accountancy

HBO Bedrijfskundige informatica

HBO Management, economie en recht

HBO SPD bedrijfsadministratie

BOL niv. 3/4 Commerciële dienstverlening

HBO Commerciële economie

HBO Management, economie en recht

BOL niv, 3/4 Economisch-juridisch

HBO Management, economie en recht

HBO Sociaal-juridische dienstverlening

BOL ZB Logistiek

BOL MKF Assistent-administrateur

HBO Leraar basisonderwijs

HBO Elektrotechniek

HBO Fiscale economie

HBO (Management) onroerend goed

HBO Journalistiek

HBO Kort Marketing management

HBO Commerciële economie

BOL niv. 3/4 Secretarieel

HBO Personeel en arbeid

HBO Communicatie

HBO Commerciële economie 
Tabel B2.2 (vervolg)

Belangrijkste opleidingen van schoolverlaters die een voltijd vervolgopleiding zijn gaan volgen

$\%$

BOL niv. 3/4 Detailhandel/ambulante handel

HBO Small business en retail management

HBO Commerciële economie

HBO (Management) onroerend goed

HBO Management, economie en recht

BOL niv. 3/4 Groothandel/distributie

HBO Communicatie

HBO Commerciële economie

HBO Management, economie en recht

HBO Kort Bedrijfskaderopleiding

BOL niv. 3/4 Horeca, instellingskeuken en contractcatering

HBO Hoger hotelonderwijs

HBO Commerciële economie

HBO Marketing

HBO Personeel en arbeid

BBL ZB Horeca, instellingskeuken en contractcatering

BOL niv. 3/4 Toerisme, recreatie en reizen

HBO Toerisme en recreatie (bedrijfsmanagement)

HBO Kort Hoger toeristisch en recreatief onderwijs

HBO Hogere Europese beroepenopleiding

BOL niv. 3/4 Assistenten gezondheidszorg

HBO Opleiding mondhygiënist

HBO Opleiding tot verpleegkundige

HBO Fysiotherapie

BOL niv. 3/4 Facilitaire dienstverlening

HBO Facilitaire dienstverlening

HBO Personeel en arbeid

BOL niv. 3/4 Sport en bewegen

HBO Fysiotherapie

HBO Leraar VO lichamelijke oefening (1e gr.)

HBO Leraar basisonderwijs

HBO Ergotherapie

HBO Leraar basisonderwijs

BOL MKF Sport en bewegen

BOL niv. 3/4 Verpleging en verzorging

HBO Opleiding tot verpleegkundige

BOL niv. 3/4 Sociaal-cultureel werker

HBO Culturele en maatschappelijke vorming HBO Sociaal pedagogische hulpverlening

HBO Leraar basisonderwijs

HBO Maatschappelijk werk en dienstverlening

BBL ZB Leidster kindercentra

HBO Leraar basisonderwijs

BOL niv. 3/4 Sociaal-pedagogisch werker HBO Sociaal pedagogische hulpverlening

HBO Leraar basisonderwijs

HBO Maatschappelijk werk en dienstverlening

HBO Leraar basisonderwijs 
Tabel B2.2 (vervolg)

Belangrijkste opleidingen van schoolverlaters die een voltijd vervolgopleiding zijn gaan volgen

$\%$

BOL niv. 3/4 Sociaal-juridische dienstverlening

HBO Sociaal-juridische dienstverlening

HBO Personeel en arbeid

28

HBO Maatschappelijk werk en dienstverlening

Zie ook toelichting bladzijde 11. De gepresenteerde percentages in deze tabel zijn soms gebaseerd op zeer kleine aantallen. 
Tabel B2.3

Oordeel van schoolverlaters over de aansluiting van de afgesloten opleiding met de voltijd vervolgopleiding

\begin{tabular}{lcccc}
\hline Opleidingsrichting & $\begin{array}{c}\text { oordeel } \\
\text { goed }\end{array}$ & $\begin{array}{c}\text { oordeel } \\
\text { vol- } \\
\text { doende } \\
\%\end{array}$ & $\begin{array}{c}\text { oordeel } \\
\text { matig }\end{array}$ & $\begin{array}{c}\text { oordeel } \\
\text { slecht }\end{array}$ \\
\hline
\end{tabular}

VBO

IVBO Landbouw en natuurlijke omgeving

Landbouw en natuurlijke omgeving

Bouwtechniek

Mechanische techniek

Elektrotechniek

Motorvoertuigentechniek

Consumptieve techniek

Administratie

Verkoop

Handel

Verzorging

Uiterlijke verzorging

Mode en kleding

$\begin{array}{rrrr}41 & 33 & 14 & 12 \\ 38 & 39 & 13 & 9 \\ 44 & 37 & 14 & 5 \\ 25 & 38 & 21 & 17 \\ 33 & 39 & 18 & 10 \\ 39 & 33 & 19 & 8 \\ 33 & 39 & 11 & 17 \\ 53 & 31 & 11 & 5 \\ 42 & 44 & 7 & 7 \\ 34 & 33 & 16 & 16 \\ 45 & 35 & 16 & 4 \\ 48 & 30 & 15 & 6 \\ 54 & 9 & 27 & 9\end{array}$

BOL niv. 1/2

Oriënteren en schakelen

Energie- en informatietechniek

Brood- en banketbakken

Bedrijfsadministratie

Secretarieel

Detailhandel/ambulante handel

Horeca, instellingskeuken en contractcatering

Verpleging en verzorging

$\begin{array}{rrrr}51 & 29 & 15 & 5 \\ 28 & 24 & 24 & 24 \\ 32 & 47 & 0 & 21 \\ 34 & 44 & 13 & 9 \\ 57 & 28 & 12 & 3 \\ 36 & 39 & 17 & 9 \\ 34 & 32 & 18 & 16 \\ 58 & 27 & 11 & 3\end{array}$

BOL niv. $3 / 4$

niv. 4 Plantenteelt

niv. 4 Veehouderij

niv. 4 Levensmiddelentechnologie

niv. 4 Bloemschikken

niv. 4 Groene ruimte

Bouw

Houtbewerking en woninginrichting

Grond-, water- en wegenbouw

Fijnmechanische techniek

Werktuigbouwkunde

Motorvoertuigen en carrosserietechniek

Energie- en informatietechniek

Mode en kleding (realisatie)

Laboratoriumtechniek

Bedrijfsadministratie

Commerciële dienstverlening

Economisch-juridisch

Secretarieel

Detailhandel/ambulante handel

Groothandel/distributie

Horeca, instellingskeuken en contractcatering

Toerisme, recreatie en reizen

Assistenten gezondheidszorg

Facilitaire dienstverlening

Sport en bewegen

Verpleging en verzorging

Sociaal-cultureel werker

Sociaal-pedagogisch werker

Sociaal-juridische dienstverlening

$\begin{array}{rrrr}12 & 51 & 30 & 8 \\ 34 & 33 & 20 & 13 \\ 43 & 34 & 19 & 4 \\ 33 & 11 & 17 & 38 \\ 32 & 34 & 30 & 4 \\ 30 & 45 & 17 & 8 \\ 53 & 26 & 5 & 16 \\ 37 & 28 & 24 & 11 \\ 26 & 42 & 16 & 16 \\ 42 & 40 & 13 & 5 \\ 40 & 53 & 3 & 3 \\ 33 & 45 & 17 & 4 \\ 27 & 38 & 23 & 12 \\ 51 & 35 & 12 & 3 \\ 41 & 40 & 13 & 7 \\ 24 & 33 & 31 & 12 \\ 22 & 47 & 31 & 0 \\ 33 & 40 & 18 & 9 \\ 23 & 40 & 23 & 14 \\ 43 & 34 & 18 & 5 \\ 31 & 31 & 33 & 5 \\ 30 & 37 & 20 & 13 \\ 26 & 38 & 24 & 12 \\ 38 & 33 & 23 & 7 \\ 43 & 35 & 17 & 5 \\ 42 & 35 & 18 & 6 \\ 33 & 36 & 22 & 8 \\ 37 & 39 & 18 & 5 \\ 42 & 36 & 14 & 8\end{array}$

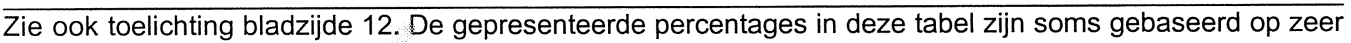
kleine aantallen. 
Tabel B2.4

Doorstroom van schoolverlaters naar de beroepsbegeleidende leerweg

IVBO Landbouw en natuurlijke omgeving

LOBAS

BOL/BBL rest

SVH

OVDB

IVBO Bouwtechniek

SVB

$\mathrm{BOL} / \mathrm{BBL}$ rest

IVBO Mechanische techniek

VTL

LOBAS

SOM

Intechnium

INNOVAM

SBW

VaPro

SVH

$\mathrm{BOL} / \mathrm{BBL}$ rest

$\mathrm{BOL} / \mathrm{BBL} / \mathrm{ln}$-service rest

18

IVBO Verzorging

OVDB

ECABO

Handel/L-OVD

9

9

9

9

9

VBO Landbouw en natuurlijke omgeving

LOBAS

BOL/BBL rest

OVDB

Handel/L-OVD

VBO Bouwtechniek

SVB

BOL/BBL rest

SH\&M

SVS

VBO Mechanische techniek

SOM

BOL/BBL rest

INNOVAM

VaPro

VBO Elektrotechniek

VEV/LOB-E

SOM

BOL/BBL rest

VBO Motorvoertuigentechniek

INNOVAM

VOC-Car

BOL/BBL rest

VTL

SOM

SBW 
Tabel B2.4 (vervolg)

Doorstroom van schoolverlaters naar de beroepsbegeleidende leerweg

\section{VBO Verzorging \\ OVDB \\ Handel/L-OVD \\ $\mathrm{BOL} / \mathrm{BBL}$ rest \\ $\mathrm{KOC}$ \\ $\mathrm{MBO}$ rest}

VBO Uiterlijke verzorging

KOC

Handel/L-OVD

$\mathrm{BOL} / \mathrm{BBL}$ rest

$B O L$ niv. 1/2 Brood- en banketbakken

SOB\&B

BOL/BBL rest

VTL

BOL niv. 1/2 Detailhandel/ambulante handel

Handel/L-OVD

ECABO

$\mathrm{BOL} / \mathrm{BBL}$ rest

BOL niv. 1/2 Horeca, instellingskeuken en contractcatering

$\mathrm{SVH}$

Handel/L-OVD

BOL/BBL rest

OVDB

$B O L$ niv. 1/2 Verpleging en verzorging

OVDB

BOL/BBL rest

BOL niv. 3/4 Detailhandel/ambulante handel

ECABO

Handel/L-OVD

OVDB

SVH

$\mathrm{BOL} / \mathrm{BBL}$ rest

$\mathrm{KOC}$

SVO

BOL niv. 3/4 Verpleging en verzorging

OVDB

In-service Ziekenverzorgende

In-service verpleegkundige $A$

$\mathrm{BOL} / \mathrm{BBL}$ rest

BOL niv. 3/4 Sociaal-pedagogisch werker

OVDB

BOL/BBL rest

ECABO

Zie ook toelichting bladzijde 15. De gepresenteerde percentages in deze tabel zijn soms gebaseerd op zeer kleine aantallen. 


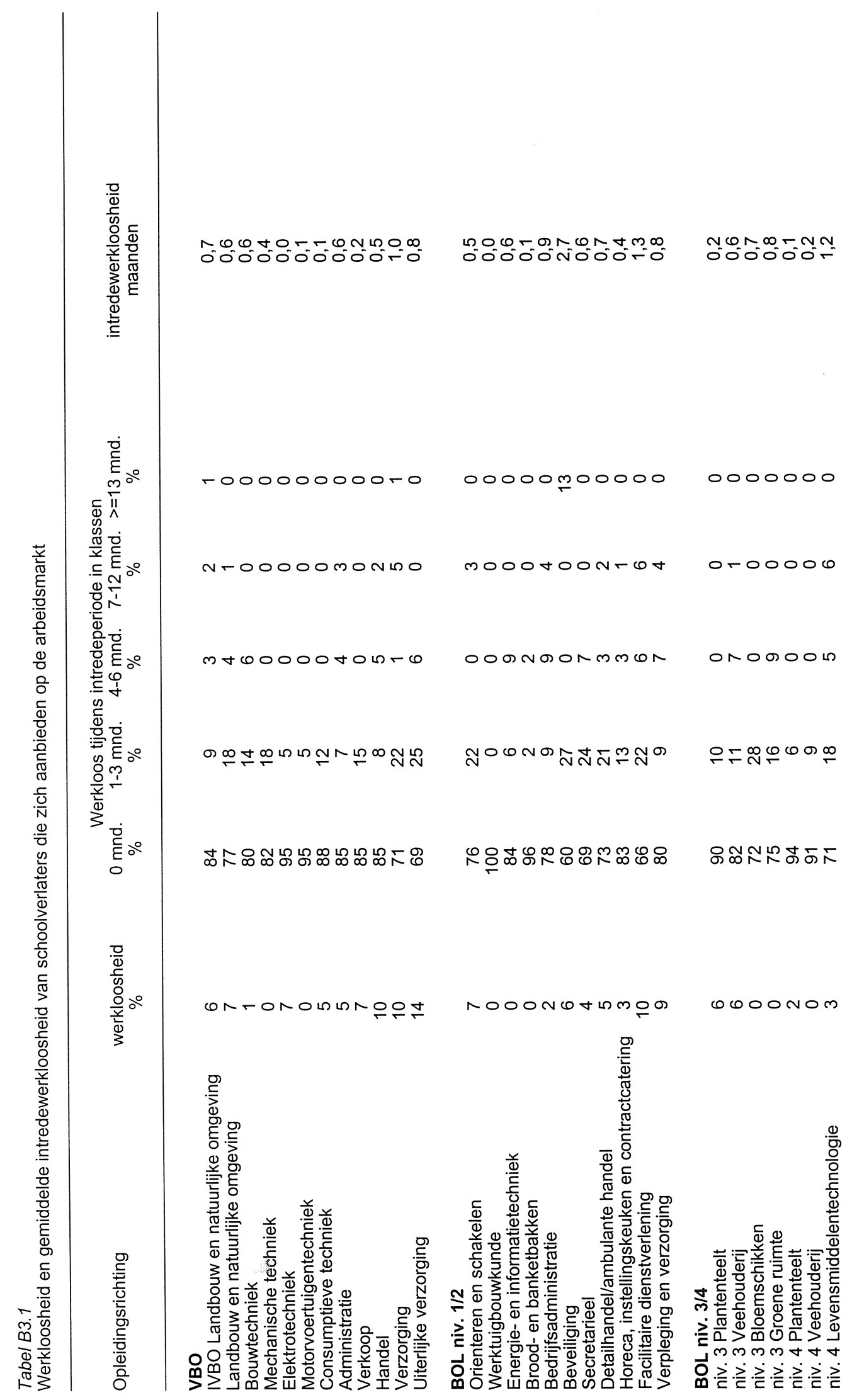




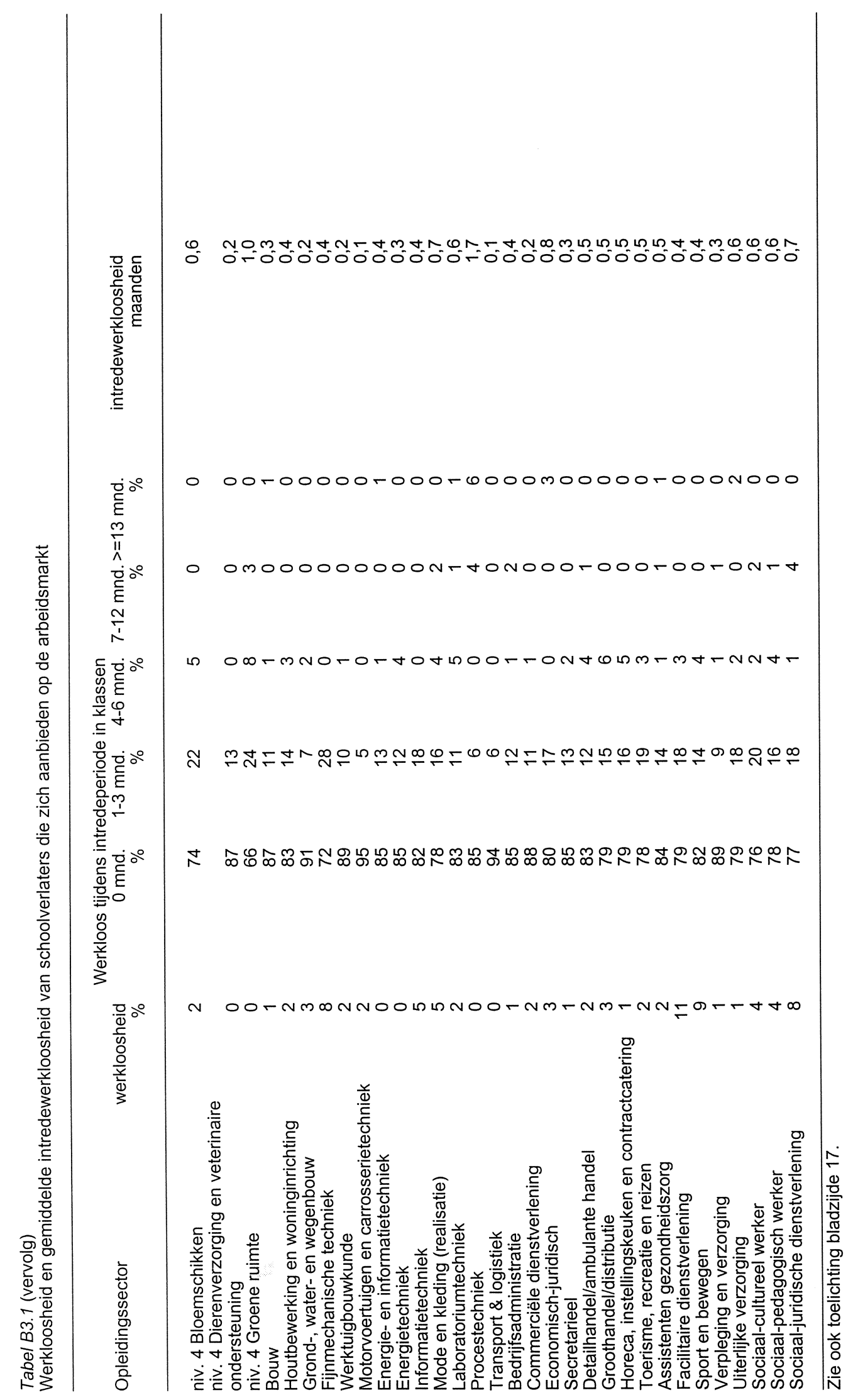




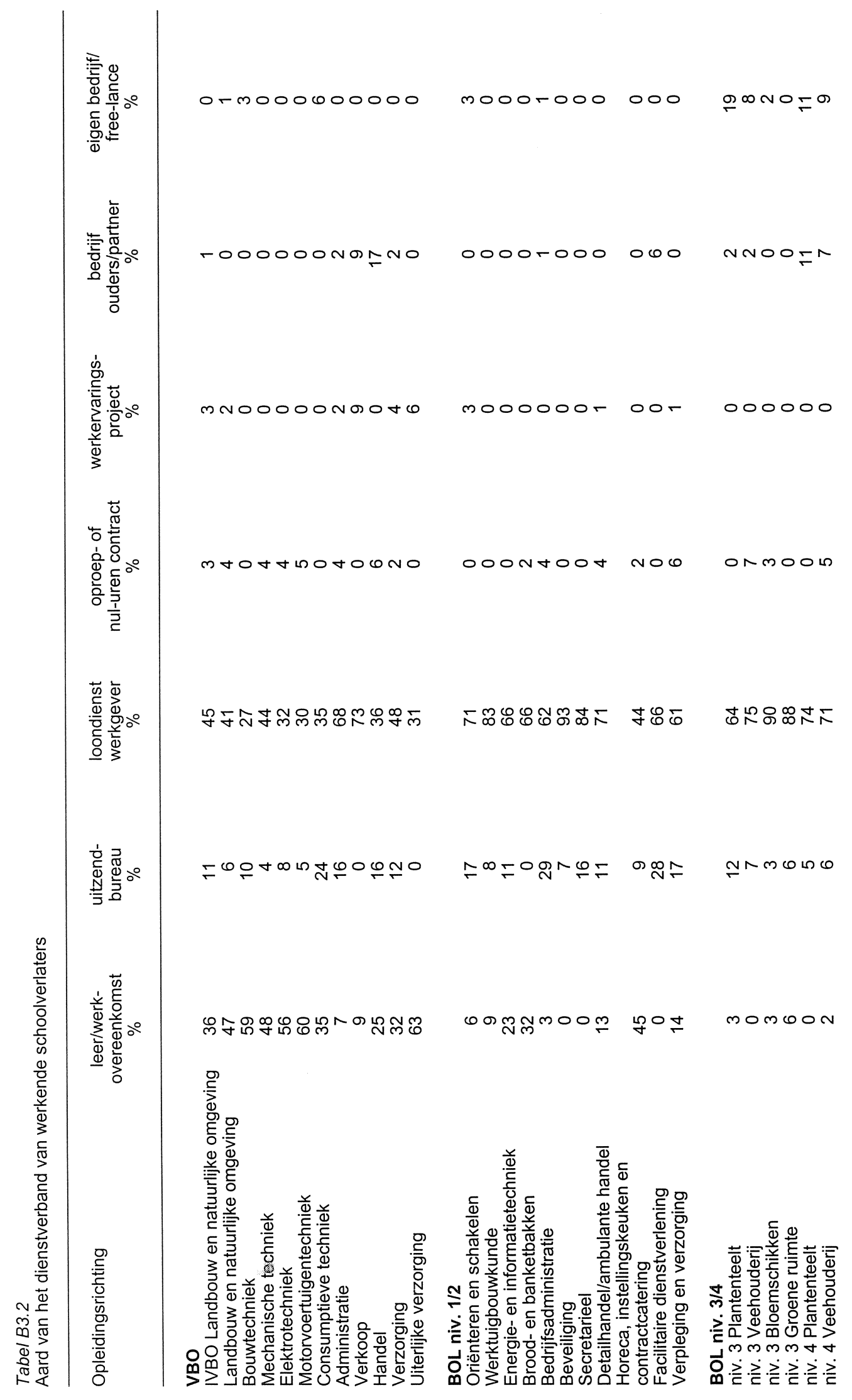




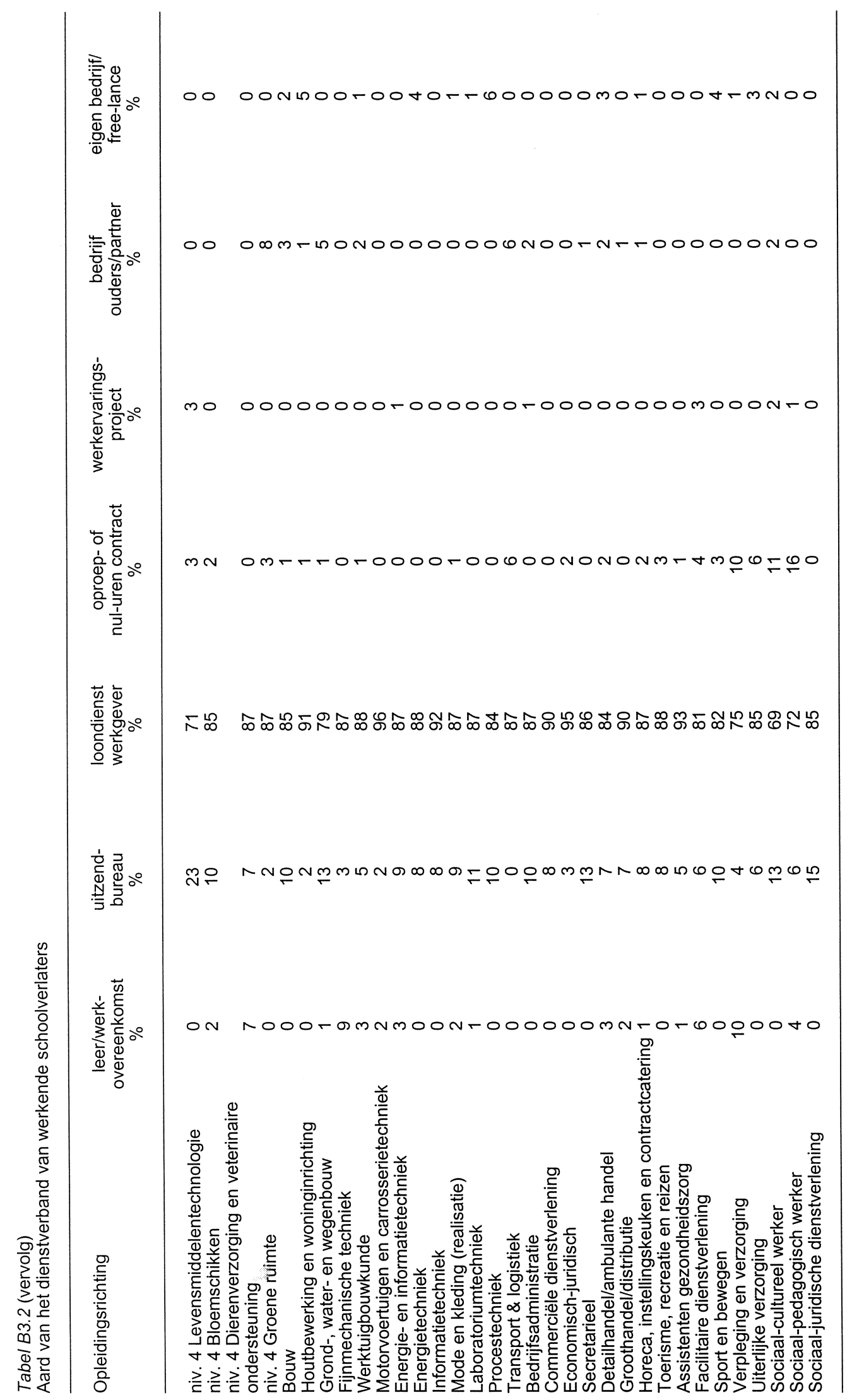


Tabel B3.3

Percentage werkende schoolverlaters met een flexibele aanstelling

Opleidingsrichting

VBO

IVBO Landbouw en natuurlijke omgeving $\quad 25$

Landbouw en natuurlijke omgeving 26

$\begin{array}{ll}\text { Bouwtechniek } & 21\end{array}$

Mechanische techniek $\quad 27$

Elektrotechniek 22

Motorvoertuigentechniek 10

$\begin{array}{lr}\text { Consumptieve techniek } & 31 \\ & 25\end{array}$

$\begin{array}{lr}\text { Administratie } & 25 \\ \text { Verkoop } & 18\end{array}$

$\begin{array}{lr}\text { Verkoop } & 18 \\ \text { Handel } & 26\end{array}$

$\begin{array}{ll}\text { Verzorging } & 21\end{array}$

Uiterlijke verzorging 13

BOL niv. $1 / 2$

Oriënteren en schakelen $\quad 22$

Werktuigbouwkunde 21

\begin{tabular}{lr} 
Energie- en informatietechniek & 11 \\
\hline & 11
\end{tabular}

Brood- en banketbakken $\quad 11$

Bedrijfsadministratie 40

\begin{tabular}{lr} 
Beveiliging & 20 \\
\hline & 29
\end{tabular}

Secretarieel 1 mbulante handel $\quad 27$

$\begin{array}{ll}\text { Detailhandel/ambulante handel } & 27 \\ \text { Horeca, instellingskeuken en contractcatering } & 23\end{array}$

Facilitaire dienstverlening $\quad 45$

Verpleging en verzorging $\quad 28$

BOL niv. $3 / 4$

niv. 3 Plantenteelt 26

niv. 3 Veehouderij $\quad 30$

niv. 3 Bloemschikken $r$

niv. 3 Groene ruimte 14

niv. 4 Plantenteelt $\quad 14$

niv. 4 Veehouderij $\quad 22$

niv. 4 Bloemschikken $\quad 27$

niv. 4 Dierenverzorging en veterinaire ondersteuning 27

niv. 4 Groene ruimte 19

Bouw 15

Houtbewerking en woninginrichting 15

Grond-, water-en wegenbouw $\quad 15$

Fijnmechanische techniek 11

$\begin{array}{lr}\text { Werktuigbouwkunde } & 11 \\ \text { Motorvoertuigen en carrosserietechniek } & 6\end{array}$

$\begin{array}{ll}\text { Energie- en informatietechniek } & 10\end{array}$

Energietechniek 1

Informatietechniek

Mode en kleding (realisatie)

Laboratoriumtechniek $\quad 17$

Procestechniek 21

Transport \& logistiek $\quad 6$

Bedrijfsadministratie 19

Commerciële dienstverlening 15

Economisch-juridisch 15

21

Detailhandel/ambulante handel 16

Groothandel/distributie 16

Horeca, instellingskeuken en contractcatering 24

Toerisme, recreatie en reizen 20

Assistenten gezondheidszorg 9

$\begin{array}{lr}\text { Facilitaire dienstverlening } & 19 \\ \text { Sport en bewegen } & 18\end{array}$

Verpleging en verzorging 
Tabel B3. 3 (vervolg)

Percentage werkende schoolverlaters met een flexibele aanstelling

Opleidingsrichting

Uiterlijke verzorging

20

Sociaal-cultureel werker

28

Sociaal-pedagogisch werker

30

Sociaal-juridische dienstverlening

26

Zie ook toelichting bladzijde 20 . 


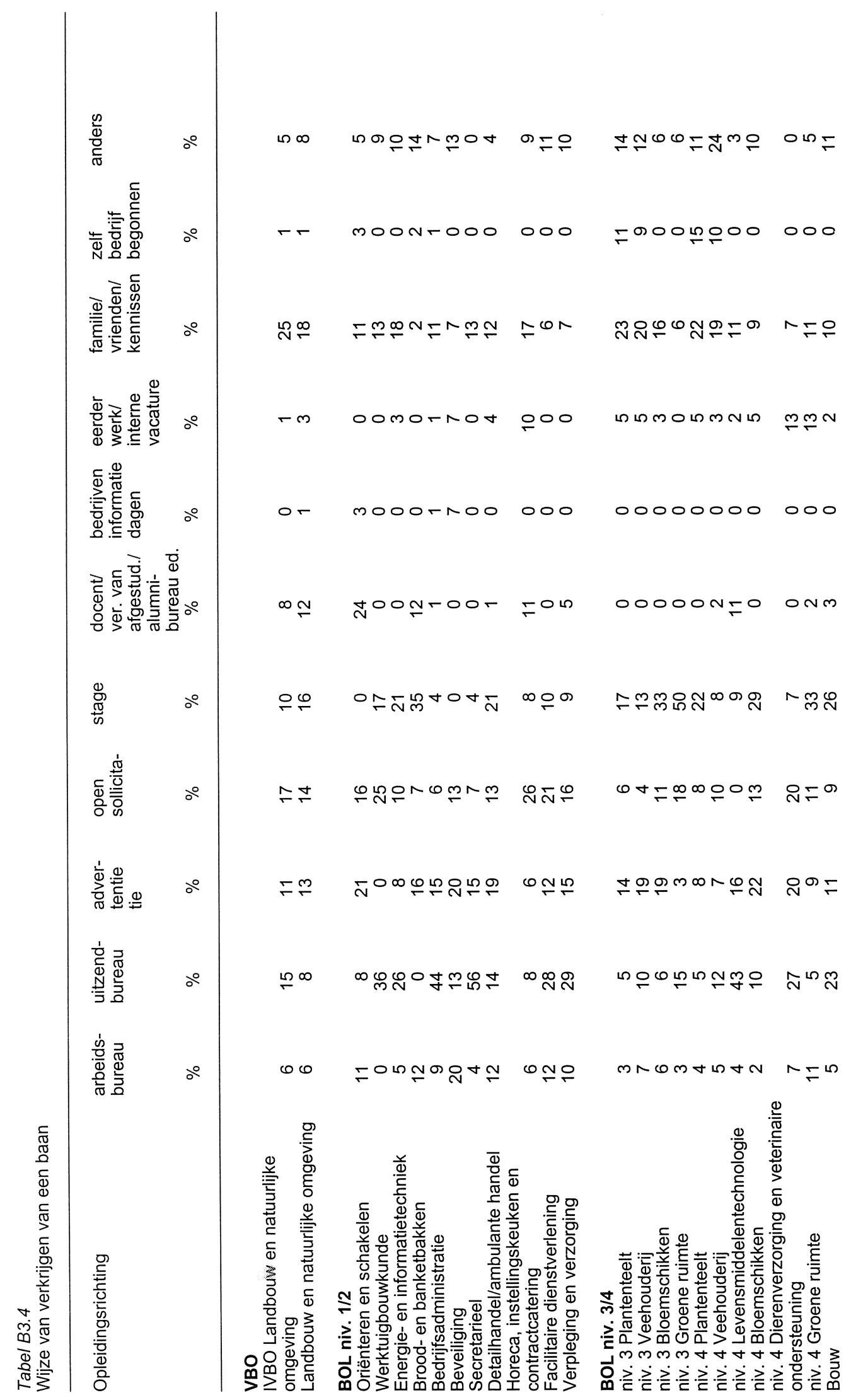




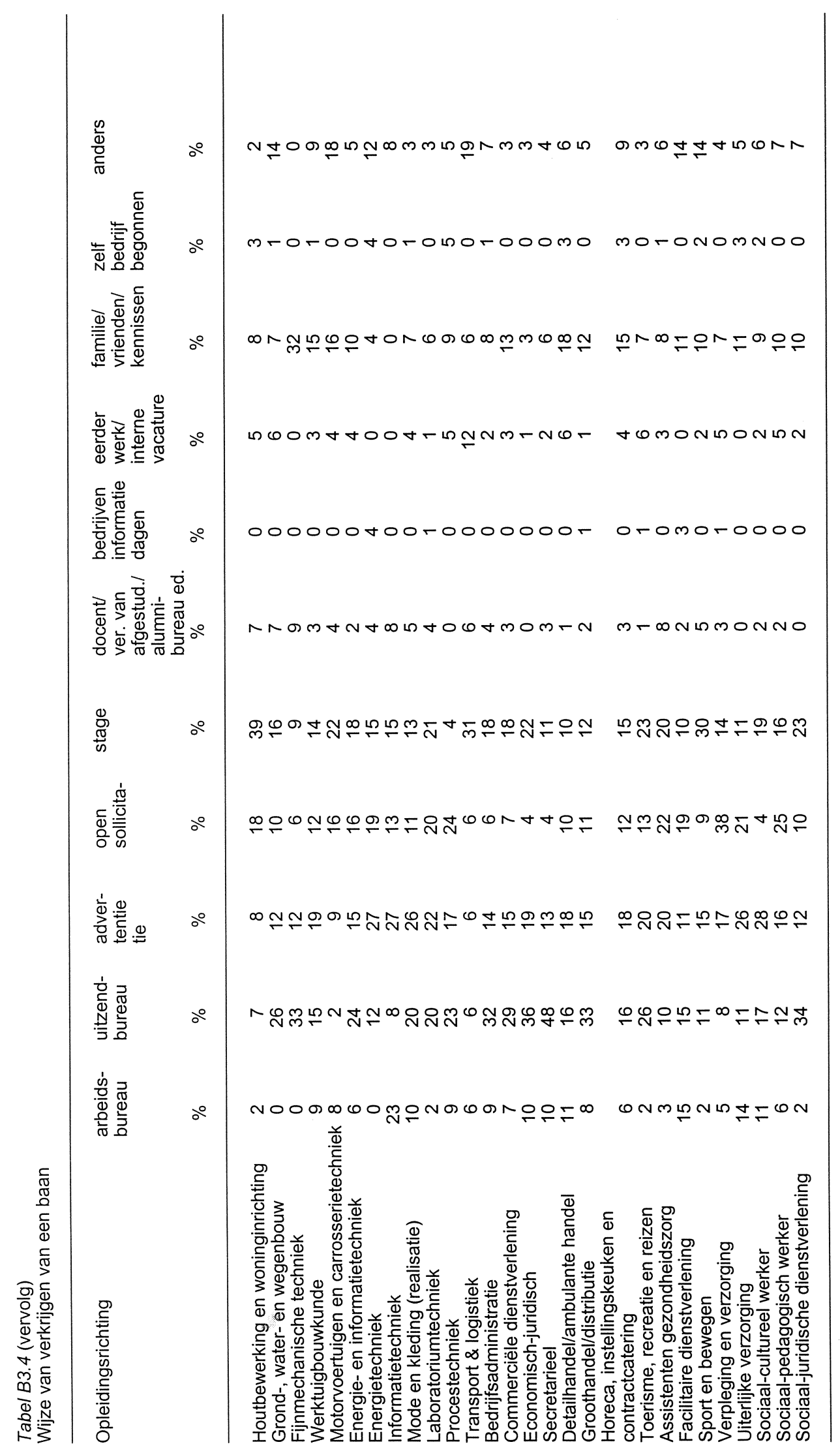


Tabel B3.5

Belangrijkste bedrijfsgroepen waarin schoolverlaters werkzaam zijn

IVBO Landbouw en natuurlijke omgeving

Ov. gespec. detailh. in winkel

Niet-gespec. detailh. in winkel

Dienstverl. tbv landb. (excl. veterin.dienst.)

Restaurants/cafetaria's/snackbars ed.

Burgerl./utilit.;grond-/water-/wegenb. (excl. grondverz.)

VBO Landbouw en natuurlijke omgeving

Ov. gespec. detailh. in winkel

Dienstverl. tbv landb. (excl. veterin.dienst.)

Akker-/tuinbouw

Restaurants/cafetaria's/snackbars ed.

VBO Bouwtechniek

Burgerl./utilit.;grond-/water-/wegenb. (excl. grondverz.)

Afwerken gebouwen

BO Mechanische techniek

Bouwinstallatie

Ov. gespec. detailh. in winkel

Vervaard. metalen constructiew./ramen/deuren/kozijnen

Burgerl./utilit.;grond-/water-/wegenb. (excl. grondverz.)

Handel in/repar. auto's (1)

Vervoer over weg

Overheidsdienst.

\section{VBO Elektrotechniek}

Bouwinstallatie

Ov. gespec. detailh. in winkel

VBO Motorvoertuigentechniek

Handel in/repar. auto's (1)

Bervoer over weg-/water-/wegenb. (excl. grondverz.)

Slachterijen/vleesverwerking

Overheidsdienst.

VBO Consumptieve techniek

Vervaard. ov. voedingsmid.

Hotels/pensions/conferentie-oorden

Restaurants/cafetaria's/snackbars ed.

Niet-gespec. detailh. in winkel

Akker-/tuinbouw

Vervaard. farmac. prod.

Vervaard. ov. mach./appar. voor alg. gebr.

Gespec. detailh. voed.-/genotmid. in winke

Detailh. farmac./med. art./parfum/cosmet. in winkel

Ov. gespec. detailh. in winkel

Reiniging gebouwen/transportmid. ed.

Welzijnszorg

VBO Administratie

Gespec. detailh. voed.-/genotmid. in winkel

Overheidsdienst.

Niet-gespec. detailh. in winke

Expedit./cargad./bevracht.;weging/meting

Gezondheidszorg

Ov. gespec. detailh. in winkel 
Tabel B3.5 (vervolg)

Belangrijkste bedrijfsgroepen waarin schoolverlaters werkzaam zijn

\section{VBO Verkoop}

Ov. gespec. detailh. in winkel 29

Niet-gespec. detailh. in winkel

Grooth. mach./appar./toebehoren

Detailh. farmac./med. art./parfum/cosmet. in winkel

Kampeerterreinen/ov. voorzien. recreat. verblijf n.e.g.

Ov. dienstverl. tbv verv. n.e.g.

Rechtsk. dienstverl./account./belastingconsul./holdings ed.

Beveiliging/opsporing

Overheidsdienst.

Welzijnszorg

VBO Handel

Ov. gespec. detailh. in winkel

Niet-gespec. detailh. in winkel

Afwerken gebouwen

Handel in/repar. auto's (1)

Grooth. ov. consumentenart.

Vervoer over weg

Vervoer over water

Reklamebureaus ed.

Milieudienstverlening

VBO Verzorging

Ov, gespec, detailh. in winkel

Ov. dienstverlening 13

Welzijnszorg 13

Restaurants/cafetaria's/snackbars ed. $\quad 11$

Niet-gespec. detailh. in winkel

Hotels/pensions/conferentie-oorden

VBO Uiterlijke verzorging

Ov. dienstverlening

Niet-gespec. detailh. in winkel

Detailh. farmac./med. art./parfum/cosmet. in winkel

Ov. gespec. detailh. in winkel

Visverwerking

Welzijnszorg

BOL niv. 1/2 Oriënteren en schakelen

Overheidsdienst.

Ov. gespec. detailh. in winkel

Niet-gespec. detailh. in winkel

Akker-/tuinbouw

BOL niv. 1/2 Constructie(bank)werken/(isolatie)plaatwerken/pijpenbewerkingen Burgerl./utilit.;grond-/water-/wegenb. (excl. grondverz.)

Vervaard. metalen constructiew./ramen/deuren/kozijnen

Overheidsdienst.

Bouwinstallatie

Ov. eerste verwerking ijzer/staal

Oppervlaktebehandeling/ov. metaalbewerking

Aardolie-/aardgaswin.

Vervaard. prod. kunststof

Vervaard. glas/glaswerk

Vervaard. prod. metaal (excl. mach./transportmid.)

Vervaard. ov. mach./appar. voor specif. ind. activ.

Vervaard. auto-onderd./-accessoir.

Ov. gespec. grooth./grooth. met een alg. assort. 
Tabel B3.5 (vervolg)

Belangrijkste bedrijfsgroepen waarin schoolverlaters werkzaam zijn

BOL niv. 1/2 Energie- en informatietechniek

Bouwinstallatie

Vervaard. ov. mach./appar. voor alg. gebr.

Ov. gespec. detailh. in winkel

Overheidsdienst.

BOL niv. 1/2 Brood- en banketbakken

Vervaard. ov. voedingsmid.

Niet-gespec. detailh. in winkel

Gespec. detailh. voed.-/genotmid. in winkel

Vervaard. mee

Restaurants/cafetaria's/snackbars ed.

Vervoer over weg

BOL niv. 1/2 Bedrijfsadministratie

Ov. gespec. detailh. in winkel

Geldscheppende financ. instell.

Akker-/tuinbouw

Niet-gespec. detailh. in winkel

BOL niv. 1/2 Beveiliging

Beveiliging/opsporing

Overheidsdienst.

Vervaard. ov. goederen n.e.g.

Niet-gespec. detailh. in winkel

Ov. gespec. detailh. in winkel

Post-/koeriersdiensten

Computerservice-/informatietechnologiebur. ed.

Reiniging gebouwen/transportmid. ed.

Voortgezet onderwijs

Gezondheidszorg

Radio/tv

BOL niv. 1/2 Secretarieel

Rechtsk. dienstverl./account./belastingconsul./holdings ed.

Grooth. mach./appar./toebehoren

Handel in/repar. auto's (1)

Uitzendbur./uitleenbedr./arbeidsbemid./testen/werven/select.

Verpl. soc. verzekeringen

Vervaard. kantoormachines/computers

Ov. dienstverl. tbv verv. n.e.g.

Geldscheppende financ. instell.

Ov. financ. instell. (excl. verzekeringsw./pensioenfonds.)

Ov. zakelijke dienstverl. n.e.g.

Hoger onderwijs

BOL niv. 1/2 Detailhandel/ambulante handel

Ov. gespec. detailh. in winkel

Niet-gespec. detailh. in winkel

Gespec. detailh. voed.-/genotmid. in winkel

BOL niv. 1/2 Horeca, instellingskeuken en contractcatering

Restaurants/cafetaria's/snackbars ed.

Hotels/pensions/conferentie-oorden

Niet-gespec. detailh. in winkel 
Tabel B3.5 (vervolg)

Belangrijkste bedriffsgroepen waarin schoolverlaters werkzaam zijn

BOL niv. 1/2 Facilitaire dienstverlening

Kantines/catering

Hotels/pensions/conferentie-oorden

12

Restaurants/cafetaria's/snackbars ed.

Vervaard. ov. voedingsmid.

Groente-/fruitverwerking

Logies-/maaltijden-/drankenverstrek.

Cafes ed.

Gezondheidszorg

Vervaard. kantoormachines/computers

Vervaard. ov. goederen n.e.g.

Gespec. detailh. voed.-/genotmid. in winkel

Levensbesch./politieke organ.;ov. ideele organ. ed.

BOL niv. 1/2 Verpleging en verzorging

Welzijnszorg

Gezondheidszorg

Niet-gespec. detailh. in winkel

Slachterijen/vleesverwerking

BOL niv. 3/4 Plantenteelt

Akker-/tuinbouw

Dienstverl. tbv landb. (excl. veterin.dienst.)

Ov. gespec. detailh. in winkel

Grooth. landbouwprod./lev. dieren

BOL niv. 3/4 Veehouderi

Fokken/houden dieren

Dienstverl. tbv landb. (excl. veterin.dienst.)

Akker-/tuinbouw

Ov. gespec. detailh. in winkel

BOL niv. 3/4 Bloemschikken

Ov. gespec. detailh. in winkel

BOL niv. 3/4 Groene ruimte

Dienstverl. tbv landb. (excl. veterin.dienst.)

Ov. gespec. detailh. in winkel

Burgerl./utilit.;grond-/water-/wegenb. (excl. grondverz.)

Vervoer over weg

BOL niv. 3/4 Plantenteelt (en handel)

Akker-/tuinbouw

Grooth. landbouwprod./lev. dieren

BOL niv. 3/4 Veehouderij

Fokken/houden dieren

Dienstverl. tbv landb. (excl. veterin.dienst.)

Ov. gespec. detailh. in winkel

Akker-/tuinbouw

Burgerl./utilit.;grond-/water-/wegenb. (excl. grondverz.)

BOL niv. 3/4 Levensmiddelentechnologie

Vervaard. zuivelprodukten

Vervaard. ov. voedingsmid.

Openbaar bestuur

Slachterijen/vleesverwerking

Fokken/houden dieren

BOL niv, 3/4 Bloemschikken

Ov. gespec. detailh. in winkel

Vervoer per spoor

Gezondheidszorg 
Tabel B3.5 (vervolg)

Belangrijkste bedrijfsgroepen waarin schoolverlaters werkzaam zijn

BOL niv. 3/4 Dierenverzorging en veterinaire ondersteuning

Veterinaire diensten

Gezondheidszorg

Cult. uitl.centra/openb. arch./musea/dieren-/plantentuin ed.

Fokken/houden dieren

Vervaard. med. appar./instrum./orthop./prothese-art.

Vervaard. meubels

Ov. gespec. detailh. in winkel

Geldscheppende financ. instell.

Bemid. in/beheer onroerend goed

Systeemontwikkelings-/systeemanalyse-/programmeerdienst.

BOL niv. 3/4 Groene ruimte

Dienstverl. tbv landb. (excl. veterin.dienst.)

Ov. gespec. detailh. in winkel

Openbaar bestuur

Akker-/tuinbouw

Natuurwet. speur-/ontwikkelingsw.

Architecten-/ingenieurs-/ov. techn.ontw.-/teken-/adviesbur.

BOL niv. 3/4 Bouw

Burgerl./utilit.;grond-/water-/wegenb. (excl. grondverz.)

Architecten-/ingenieurs-/ov. techn.ontw.-/teken-/adviesbur.

Openbaar bestuur

Afwerken gebouwen

BOL niv. 3/4 Houtbewerking en woninginrichting

Vervaard. meubels

Ov. gespec. detailh. in winkel

Vervaard. timmerw.

Scheepsbouw/-reparatie

Vervaard. meubels;vervaard. ov. goederen n.e.g.

BOL niv. 3/4 Grond-, water-en wegenbouw

Burgerl./utilit.;grond-/water-/wegenb. (excl. grondverz.)

Openbaar bestuur

Architecten-/ingenieurs-/ov. techn.ontw.-/teken-/adviesbur.

Bouwrijp maken terreinen

BOL niv. 3/4 Fijnmechanische techniek

Vervaard. ov. mach./appar. voor specif. ind. activ.

Oppervlaktebehandeling/ov. metaalbewerking

Vervaard. scharen/bestek/gereedsch./hang-/sluitw.

Vervaard. mach./appar.

Vervaard. vlieg-/ruimtevaart.

Benzineservicestations

Gezondheidszorg

Hoger onderwijs

\section{BOL niv. 3/4 Werktuigbouwkunde}

Bouwinstallatie

Vervaard. ov. mach./appar. voor specif. ind. activ.

Vervaard. ov. mach./appar. voor alg. gebr.

Architecten-/ingenieurs-/ov. techn.ontw.-/teken-/adviesbur.

BOL niv. 3/4 Motorvoertuigen en carrosserietechniek Handel in/repar. auto's (1) 
Tabel B3.5 (vervolg)

Belangrijkste bedrijfsgroepen waarin schoolverlaters werkzaam zijn

BOL niv. 3/4 Energie- en informatietechniek

Bouwinstallatie

Overheidsdienst

Telecommunicatie

Vervaard. ov. mach./appar. voor alg. gebr.

BOL niv. 3/4 Informatietechniek

Telecommunicatie

Bouwinstallatie

Adviesbur. op gebied automat./systeemh.

Vervaard. kantoormachines/computers

Grooth. mach./appar./toebehoren

Computerservice-/informatietechnologiebur. ed.

Systeemontwikkelings-/systeemanalyse-/programmeerdienst.

Rechtsk. dienstverl./account./belastingconsul./holdings ed.

Openbaar bestuur

Ov. dienstverlening

BOL niv. 3/4 Mode en kleding

Ov. gespec. detailh. in winkel

Grooth. ov. consumentenart.

Vervaard. kleding/-toebehoren (excl. leer)

Niet-gespec. detailh. in winkel

BOL niv. 3/4 Laboratoriumtechniek

Gezondheidszorg

Natuurwet. speur-/ontwikkelingsw.

Vervaard basischemicalien

Vervaard. ov. chem. prod.

Vervaard. ov. voedingsmid.

Vervaard. prod. kunststof

Vervaard. chem. prod.

Vervaard. basischemicalien

Vervaard. zeep-,was-,reinig.-/onderhoudsmid.,parfum/cosmet.

Vervaard. ov. prod. metaal (excl. mach./transportmid.)

Vervaard. auto-onderd./-accessoir.

Vervaard. vlieg-/ruimtevaart.

Grooth. landbouwprod./lev. dieren

Computerservice-/informatietechnologiebur. ed.

BOL niv. 3/4 Transport \& logistiek

Vervoer over weg

Expedit./cargad./bevracht.;weging/meting

Vervaard. ov. elektr. mach./appar./benodigdh.

Grooth. voedings-/genotmid.

Grooth. mach./appar./toebehoren

Vervoer over land

BOL niv. 3/4 Bedrijfsadministratie

Rechtsk. dienstverl./account./belastingconsul./holdings ed.

Openbaar bestuur

Geldscheppende financ. instell.

BOL niv. 3/4 Commerciële dienstverlening

Geldscheppende financ. instell. 
Tabel B3.5 (vervolg)

Belangrijkste bedrijfsgroepen waarin schoolverlaters werkzaam zijn

BOL niv. 3/4 Economisch-juridisch

Rechtsk. dienstverl./account./belastingconsul./holdings ed.

Openbaar bestuur

Verpl. soc. verzekeringen

Geldscheppende financ. instell.

Verzekeringsw./pensioenfonds. (excl. verpl. soc.verzek.)

Overheidsdienst.

Adviesbur. op gebied automat./systeemh.

Uitzendbur./uitleenbedr./arbeidsbemid./testen/werven/select.

12

12

5

BOL niv. 3/4 Secretarieel

Rechtsk. dienstverl./account./belastingconsul./holdings ed.

Geldscheppende financ. instell.

Bemid. in/beheer onroerend goed

Adviesbur. op gebied automat./systeemh.

BOL niv. 3/4 Detailhandel/ambulante handel

Ov. gespec. detailh. in winkel

Niet-gespec. detailh. in winkel

BOL niv. 3/4 Groothandel/distributie

Activ. verzekeringsw./pensioenfonds.

Geldscheppende financ. instell.

Telecommunicatie

Grooth. voedings-/genotmid.

Ov. gespec. detailh. in winkel

BOL niv. 3/4 Horeca, instellingskeuken en contractcatering

Hotels/pensions/conferentie-oorden

Restaurants/cafetaria's/snackbars ed.

BOL niv. 3/4 Toerisme, recreatie en reizen

Reisorgan./-bemid.;informatieverstrek. op gebied toerisme 36

Hotels/pensions/conferentie-oorden

Geldscheppende financ. instell.

BOL niv. 3/4 Assistenten gezondheidszorg

Gezondheidszorg

Detailh. farmac./med. art./parfum/cosmet. in winkel

BOL niv. 3/4 Facilitaire dienstverlening

Restaurants/cafetaria's/snackbars ed.

Welzijnszorg

Gespec. detailh. voed.-/genotmid. in winke

Hotels/pensions/conferentie-oorden

Kantines/catering

Geldscheppende financ. instell.

Overheidsdienst.

BOL niv. 3/4 Sport en bewegen

Sport

Overheidsdienst.

Kampeerterreinen/ov. voorzien. recreat. verblijf n.e.g.

Welzijnszorg

BOL niv. 3/4 Verpleging en verzorging

Welzijnszorg

Gezondheidszorg

BOL niv. 3/4 Uiterlijke verzorging

Ov. dienstverlening

Ov. gespec. detailh. in winkel

Detailh. farmac./med. art./parfum/cosmet. in winkel 
Tabel B3.5 (vervolg)

Belangrijkste bedrijfsgroepen waarin schoolverlaters werkzaam zijn

BOL niv. 3/4 Sociaal-cultureel werker

Welzijnszorg

BOL niv. 3/4 Sociaal-pedagogisch werker

Welzijnszorg

BOL niv. 3/4 Sociaal-juridische dienstverlening

Openbaar bestuur

15

Verpl. soc. verzekeringen

Uitzendbur./uitleenbedr./arbeidsbemid./testen/werven/select.

Welzijnszorg

14
6

Zie ook toelichting bladzijde 26 . 
Tabel B3.6

Belangrijkste beroepsgroepen waarin schoolverlaters werkzaam zijn

IVBO Landbouw en natuurlijke omgeving

Agrarische arbeider

Verkopers

Laders en lossers

Bouwvakkers

Hulpkrachten horeca en verzorging

Metaalarbeiders

VBO Landbouw en natuurlijke omgeving

Verkopers

Agrarische arbeider

Hulpkrachten horeca en verzorging

Bouwvakkers

Laders en lossers

Interieurverzorger

VBO Bouwtechniek

Bouwvakkers

Productiemedewerker

VBO Mechanische techniek

Metaalarbeiders

Laders en lossers

Assembleurs

Bouwvakkers

Bankwerkers en lassers

VBO Elektrotechniek

Elektromonteurs

Monteurs en controleurs elektrotechnische producten

Bouwvakkers

Aannemers en installateurs

VBO Motorvoertuigentechniek

Assembleurs

Monteurs

Laders en lossers

Chauffeurs

Metaalarbeiders

VBO Consumptieve techniek

Productiemedewerker

Hulpkrachten horeca en verzorging

Verkopers

Interieurverzorger

Mechanisch operators

Agrarische arbeider

Bakkers en slagers

VBO Administratie

Receptionisten en administratieve employés

Verkopers

Aspirant politieagenten, soldaten en beveiligingshulpkrachten

Hulpkrachten horeca en verzorging

Laders en lossers

Vakkenvuller

Agrarische arbeider

Interieurverzorger 
Tabel B3.6 (vervolg)

Belangrijkste beroepsgroepen waarin schoolverlaters werkzaam zijn

\section{VBO Verkoop}

Verkopers

Laders en lossers

Productiemedewerker

Receptionisten en administratieve employés

Aspirant politieagenten, soldaten en beveiligingshulpkrachten

Commercieel employés

Verzorgend personeel

7

VBO Handel

Verkopers

Confectie-arbeiders

Productiemedewerker

Laders en lossers

Receptionisten en administratieve employés

Chauffeurs

Verzekeringsagenten

\section{VBO Verzorging}

Hulpkrachten horeca en verzorging

Verkopers

Productiemedewerker

VBO Uiterlijke verzorging

Hulpkrachten horeca en verzorging

Verkopers

Mechanisch operators

Receptionisten en administratieve employés

Verzorgend personeel

\section{BOL niv. 1/2 Oriënteren en schakelen}

Verkopers

Aspirant politieagenten, soldaten en beveiligingshulpkrachten

Agrarische arbeider

Laders en lossers

Interieurverzorger

Receptionisten en administratieve employés

Hulpkrachten horeca en verzorging

BOL niv. 1/2 Constructie(bank)werken/(isolatie)plaatwerken/pijpenbewerkingen Metaalarbeiders

Monteurs

Aspirant politieagenten, soldaten en beveiligingshulpkrachten

Bankwerkers en lassers

Elektronicamonteurs

Bouwvakkers

BOL niv. 1/2 Energie- en informatietechniek

Elektromonteurs

Monteurs en controleurs elektrotechnische producten

Elektronicamonteurs

Bouwvakkers

Aspirant politieagenten, soldaten en beveiligingshulpkrachten

Monteurs 
Tabel B3. 6 (vervolg)

Belangrijkste beroepsgroepen waarin schoolverlaters werkzaam zijn

BOL niv. 1/2 Brood- en banketbakken

Bakkers en slagers

Verkopers

Procesoperators

Productiemedewerker

Laders en lossers

Mechanisch operators

Verzorgend personeel

7

7

5

5

BOL niv. 1/2 Bedrijfsadministratie

Receptionisten en administratieve employés

Boekhouders en secretaresses

Verkopers

Commercieel employés

BOL niv. 1/2 Beveiliging

Aspirant politieagenten, soldaten en beveiligingshulpkrachten Receptionisten en administratieve employés

Interieurverzorger

Conciërges

Chauffeurs

Verkopers

Hoofden technische dienst

Bankwerkers en lassers

Programmeurs

BOL niv. 1/2 Secretarieel

Receptionisten en administratieve employés

Boekhouders en secretaresses

Commercieel employés

BOL niv, 1/2 Detailhandel/ambulante handel

Verkopers

Receptionisten en administratieve employés

Chauffeurs

Winkeliers

BOL niv. 1/2 Horeca, instellingskeuken en contractcatering

Hulpkrachten horeca en verzorging

Verzorgend personeel

Verkopers

BOL niv. 1/2 Facilitaire dienstverlening

Hulpkrachten horeca en verzorging

nterieurverzorger

Productiemedewerker

Laders en lossers

Receptionisten en administratieve employés

Bedrijfshoofden horeca

Mechanisch operators

Verkopers

BOL niv. 1/2 Verpleging en verzorging

Hulpkrachten horeca en verzorging

verzorgend personeel

Verkopers

Verpleeghulpen en leerling-verpleegkundigen Receptionisten en administratieve employés

Ziekenverzorgenden

Mechanisch operators 
Tabel B3.6 (vervolg)

Belangrijkste beroepsgroepen waarin schoolverlaters werkzaam zijn

BOL niv. 3/4 Plantenteelt

Agrarische arbeider

Agrarische bedrijfshoofden

Landbouwmachinebestuurders en vissers

Weg- en waterbouwkundige vakkrachten

Verkopers

BOL niv. 3/4 Veehouderi

Agrarische arbeider

Verkopers

Landbouwmachinebestuurders en vissers

Weg- en waterbouwkundige vakkrachten

Agrarische bedrijfshoofden

BOL niv. 3/4 Bloemschikken

Verkopers

BOL niv. 3/4 Groene ruimte

Agrarische bedrijfshoofden

Verkopers

Weg- en waterbouwkundige arbeiders

Chauffeurs

BOL niv. 3/4 Plantenteelt (en handel)

Agrarische bedrijfshoofden

Agrarische arbeide

Commercieel employés

Agrarische vakkrachten

BOL niv. 3/4 Veehouderij

Agrarische arbeider

Agrarische bedrijfshoofden

Verkopers

Landbouwmachinebestuurders en vissers

Chauffeurs

BOL niv. 3/4 Levensmiddelentechnologie

Procesoperators

Mechanisch operators

Agrarische vakkrachten

Agrarische arbeider

Boekhouders en secretaresses

Productiemedewerker

BOL niv. 3/4 Bloemschikken

Verkopers

Hulpkrachten horeca en verzorging

Agrarische bedrijfshoofden

Agrarische vakkrachten

BOL niv. 3/4 Dierenverzorging en veterinaire ondersteuning

Verplegenden en doktersassistenten

Receptionisten en administratieve employés

Hulpkrachten horeca en verzorging

Agrarische vakkrachten

Agrarische arbeider

Apothekersassistenten en medisch laboranten

Commercieel employés

Winkeliers 
Tabel B3.6 (vervolg)

Belangrijkste beroepsgroepen waarin schoolverlaters werkzaam zijn

BOL niv. 3/4 Groene ruimte

Agrarische bedrijfshoofden

Agrarische arbeider

Agrarische vakkrachten

Verkopers

Weg- en waterbouwkundige vakkrachten

Winkeliers

BOL niv. 3/4 Bouw

Aannemers en installateurs

Weg- en waterbouwkundige vakkrachten

BOL niv. 3/4 Houtbewerking en woninginrichting

Aannemers en installateurs

Verkopers

Confectie-arbeiders

Schoen- en kleermakers

Productieplanners

Commercieel employés

BOL niv. 3/4 Grond-, water-en wegenbouw

Weg- en waterbouwkundige vakkrachten

Aannemers en installateurs

BOL niv. 3/4 Fijnmechanische techniek

Bankwerkers en lassers

Monteurs

Verkopers

Apothekersassistenten en medisch laboranten

BOL niv. 3/4 Werktuigbouwkunde

Monteurs

Bankwerkers en lassers

Aannemers en installateurs

Metaalarbeiders

BOL niv. 3/4 Motorvoertuigen en carrosserietechniek

Monteurs

Chauffeurs

Receptionisten en administratieve employés

Boekhouders en secretaresses

Commercieel employés

BOL niv. 3/4 Energie- en informatietechniek

Elektromonteurs

Elektronicamonteurs

Monteurs

Programmeurs

BOL niv. 3/4 Informatietechniek

Elektronicamonteurs

Programmeurs

Elektromonteurs

Systeemanalisten

Winkeliers

Monteurs en controleurs elektrotechnische producten

Aannemers en installateurs 
Tabel B3.6 (vervolg)

Belangrijkste beroepsgroepen waarin schoolverlaters werkzaam zijn

BOL niv. 3/4 Mode en kleding

Verkopers

Schoen- en kleermakers

Commercieel employés

Confectie-arbeiders

Receptionisten en administratieve employés

Winkeliers

Boekhouders en secretaresses

BOL niv. 3/4 Laboratoriumtechniek

Laboranten

Apothekersassistenten en medisch laboranten

BOL niv. 3/4 Procestechniek

Procesoperators

Monteurs

Programmeurs

Elektronicamonteurs

Productiemedewerker

Metaalarbeiders

Winkeliers

BOL niv. 3/4 Transport \& logistiek

Productieplanners

Chauffeurs

Commercieel employés

Receptionisten en administratieve employés

Schippers en conducteurs

Administratieve transportemployés

Vliegers, scheepskapiteins en leidinggevenden transport

BOL niv. $3 / 4$ Bedrijfsadministratie

Boekhouders en secretaresses

Receptionisten en administratieve employés

Commercieel employés

Productieplanners

BOL niv. 3/4 Commerciële dienstverlening

Commercieel employés

Receptionisten en administratieve employés

Boekhouders en secretaresses

Verkopers

BOL niv. 3/4 Economisch-juridisch

Boekhouders en secretaresses

Receptionisten en administratieve employés

Commercieel employés

Programmeurs

Juridisch en fiscaal medewerkers

Productieplanners

BOL niv. 3/4 Secretarieel

Boekhouders en secretaresses

Receptionisten en administratieve employés

Commercieel employés

BOL niv. 3/4 Detailhandel/ambulante handel

Verkopers

Winkeliers

Commercieel employés

Receptionisten en administratieve employés

Boekhouders en secretaresses 
Tabel B3.6 (vervolg)

Belangrijkste beroepsgroepen waarin schoolverlaters werkzaam zijn

BOL niv. 3/4 Groothandel/distributie

Commercieel employés

Boekhouders en secretaresses

Receptionisten en administratieve employés

Verkopers

Productieplanners

BOL niv. 3/4 Horeca, instellingskeuken en contractcatering

Hulpkrachten horeca en verzorging

Bedrijfshoofden horeca

Verzorgend personeel

Receptionisten en administratieve employés

Boekhouders en secretaresses

BOL niv. 3/4 Toerisme, recreatie en reizen

Commercieel employés

Receptionisten en administratieve employés

Boekhouders en secretaresses

Stewards

Verkopers

BOL niv. 3/4 Assistenten gezondheidszorg

Verplegenden en doktersassistenten

Apothekersassistenten en medisch laboranten

BOL niv. 3/4 Facilitaire dienstverlening

Hulpkrachten horeca en verzorging

Verzorgend personeel

Interieurverzorger

Receptionisten en administratieve employés

Bedrijfshoofden horeca

Commercieel employés

Chauffeurs

BOL niv. 3/4 Sport en bewegen

Sportinstructeurs

Zweminstructeur

Activiteitenbegeleiders en medewerkers arbeidsbemiddeling

Aspirant politieagenten, soldaten en beveiligingshulpkrachten

BOL niv. 3/4 Verpleging en verzorging

Verzorgend personeel

Verplegenden en doktersassistenten

Ziekenverzorgenden

Verpleeghulpen en leerling-verpleegkundigen

BOL niv. 3/4 Uiterlijke verzorging

Verzorgend personeel

Verkopers

Receptionisten en administratieve employés

Hulpkrachten horeca en verzorging

BOL niv. 3/4 Sociaal-cultureel werker

Verzorgend personeel

Activiteitenbegeleiders en medewerkers arbeidsbemiddeling

BoL niv. 3/4 Sociaal-pedagogisch werke

Verzorgend personeel

Activiteitenbegeleiders en medewerkers arbeidsbemiddeling

Hulpkrachten horeca en verzorging

Verkopers 
Tabel B3.6 (vervolg)

Belangrijkste beroepsgroepen waarin schoolverlaters werkzaam zijn

BOL niv. 3/4 Sociaal-juridische dienstverlening

Boekhouders en secretaresses

Activiteitenbegeleiders en medewerkers arbeidsbemiddeling

Receptionisten en administratieve employés

Verzekeringsagenten

Zie ook toelichting bladzijde 30 . 
Tabel B3.7

Grootte van de organisatie waarin schoolverlaters werkzaam zijn

\begin{tabular}{|c|c|c|c|c|c|}
\hline Opleidingsrichting & $\begin{array}{c}1 \text { pers } \\
\%\end{array}$ & $\begin{array}{c}2 \mathrm{t} / \mathrm{m} 9 \\
\text { pers } \\
\%\end{array}$ & $\begin{array}{c}10 \mathrm{t} / \mathrm{m} 99 \\
\text { pers } \\
\%\end{array}$ & $\begin{array}{c}100 \mathrm{t} / \mathrm{m} \\
999 \text { pers } \\
\%\end{array}$ & $\begin{array}{c}>=1000 \\
\text { pers } \\
\%\end{array}$ \\
\hline
\end{tabular}

VBO

IVBO Landbouw en natuurlijke omgeving

Landbouw en natuurlijke omgeving

Bouwtechniek

Mechanische techniek

Elektrotechniek

Motorvoertuigentechniek

Consumptieve techniek

Administratie

Verkoop

Handel

Verzorging

Uiterlijke verzorging

4

32
42
19
7
15
13
11
14
26

$\begin{array}{rrr}36 & 16 & 1 \\ 32 & 9 & 14 \\ 53 & 18 & \\ 52 & 26 & 11 \\ 46 & 19 & 1 \\ 57 & 13 & 17 \\ 55 & 30 & 1 \\ 40 & 30 & 19 \\ 29 & 36 & 2 \\ 31 & 13 & 19 \\ 37 & 20 & 17 \\ 39 & 11 & \end{array}$

12

BOL niv. 1/2

Oriënteren en schakelen

Werktuigbouwkunde

Energie- en informatietechniek

Brood- en banketbakken

Bedrijfsadministratie

Beveiliging

Secretarieel

Detailhandel/ambulante handel

Horeca, instellingskeuken en contractcatering

Facilitaire dienstverlening

Verpleging en verzorging

BOL niv. $3 / 4$

niv. 3 Plantenteelt

niv. 3 Veehouderij

niv. 3 Bloemschikken

niv. 3 Groene ruimte

niv. 4 Plantenteelt

niv, 4 Veehouderi

niv. 4 Levensmiddelentechnologie

niv. 4 Bloemschikken

niv 4 Dierenverzorging en veterinaire

ondersteuning

niv. 4 Groene ruimte

Bouw

Houtbewerking en woninginrichting

Grond-, water- en wegenbouw

Fijnmechanische techniek

Werktuigbouwkunde

Motorvoertuigen en carrosserietechniek

Energie- en informatietechniek

Energietechniek

Informatietechniek

Mode en kleding (realisatie)

aboratoriumtechniek

Procestechniek

Transport \& logistiek

Bedrijfsadministratie

Commerciële dienstverlening

Economisch-juridisch

Secretariee

Detailhandel/ambulante handel

Groothandel/distributie

Horeca, instellingskeuken en contractcatering

Toerisme, recreatie en reizen

Assistenten gezondheidszorg

$\begin{array}{rrrrr}3 & 18 & 21 & 18 & 39 \\ 0 & 13 & 40 & 9 & 38 \\ 0 & 24 & 39 & 18 & 18 \\ 0 & 40 & 24 & 19 & 16 \\ 1 & 14 & 22 & 32 & 31 \\ 0 & 0 & 20 & 33 & 47 \\ 0 & 16 & 35 & 26 & 24 \\ 0 & 25 & 43 & 10 & 22 \\ 0 & 23 & 55 & 13 & 9 \\ 0 & 11 & 61 & 6 & 22 \\ 1 & 6 & 32 & 37 & 24\end{array}$


Tabel B3.7 (vervolg)

Grootte van de organisatie waarin schoolverlaters werkzaam zijn

\begin{tabular}{lccccc}
\hline Opleidingsrichting & 1 pers & $\begin{array}{c}2 \mathrm{t} / \mathrm{m} 9 \\
\text { pers } \\
\%\end{array}$ & $\begin{array}{c}10 \mathrm{t} / \mathrm{m} 99 \\
\text { pers } \\
\%\end{array}$ & $\begin{array}{c}100 \mathrm{t} / \mathrm{m} \\
\%\end{array}$ & $\begin{array}{c}>=1000 \\
\text { pers } \\
\%\end{array}$ \\
\hline Facilitaire dienstverlening & 0 & 10 & 36 & 20 & 33 \\
Sport en bewegen & 2 & 27 & 36 & 17 & 17 \\
Verpleging en verzorging & 0 & 1 & 22 & 47 & 29 \\
Uiterlijke verzorging & 5 & 38 & 39 & 12 & 6 \\
Sociaal-cultureel werker & 2 & 11 & 33 & 44 & 9 \\
Sociaal-pedagogisch werker & 0 & 8 & 33 & 39 & 37 \\
Sociaal-juridische dienstverlening & 0 & 6 & 26 & 31 & 37 \\
\hline
\end{tabular}

Zie ook toelichting bladzijde 31 . 
Tabel B3.8

Beloning van werkende schoolverlaters

\begin{tabular}{|c|c|c|}
\hline Opleidingsrichting & $\begin{array}{l}\text { emiddeld } \\
\text { o maandloon } \\
\text { guldens }\end{array}$ & $\begin{array}{l}\text { gemiddeld } \\
\text { bruto uurloon } \\
\text { guldens }\end{array}$ \\
\hline \multicolumn{3}{|l|}{ VBO } \\
\hline IVBO Landbouw en natuurlijke omgeving & 1.198 & 8,19 \\
\hline Landbouw en natuurlijke omgeving & 1.109 & 8,09 \\
\hline Bouwtechniek & 1.462 & 9,77 \\
\hline Mechanische techniek & 1.203 & 7,69 \\
\hline Elektrotechniek & 1.102 & 8,13 \\
\hline Motorvoertuigentechniek & 1.331 & 9,00 \\
\hline Consumptieve techniek & 1.267 & 8,49 \\
\hline Administratie & 1.323 & 9,06 \\
\hline Verkoop & 1.108 & 8,63 \\
\hline Handel & 1.238 & 7,89 \\
\hline Verzorging & 1.102 & 8,13 \\
\hline Uiterlijke verzorging & 917 & 7,02 \\
\hline \multicolumn{3}{|l|}{ BOL niv. $1 / 2$} \\
\hline Oriënteren en schakelen & 1.699 & 10,63 \\
\hline Werktuigbouwkunde & 2.338 & 14,10 \\
\hline Energie- en informatietechniek & 1.911 & 12,08 \\
\hline Brood- en banketbakken & 1.881 & 12,33 \\
\hline Bedrijfsadministratie & 2.180 & 15,93 \\
\hline Beveiliging & 2.784 & 18,83 \\
\hline Secretarieel & 2.376 & 14,51 \\
\hline Detailhandel/ambulante handel & 1.585 & 11,04 \\
\hline Horeca, instellingskeuken en contractcatering & 1.820 & 12,12 \\
\hline Facilitaire dienstverlening & 1.981 & 12,97 \\
\hline Verpleging en verzorging & 1.536 & 11,93 \\
\hline \multicolumn{3}{|l|}{ BOL niv. $3 / 4$} \\
\hline niv. 3 Plantenteelt & 2.565 & 15,19 \\
\hline niv. 3 Veehouderij & 2.205 & 12,97 \\
\hline niv. 3 Bloemschikken & 1.844 & 12,12 \\
\hline niv. 3 Groene ruimte & 2.269 & 14,07 \\
\hline niv. 4 Plantenteelt & 2.910 & 18,04 \\
\hline niv. 4 Veehouderij & 2.550 & 15,46 \\
\hline niv. 4 Levensmiddelentechnologie & 2.864 & 18,05 \\
\hline niv. 4 Bloemschikken & 2.148 & 14,25 \\
\hline niv. 4 Dierenverzorging en veterinaire ondersteuning & 1.997 & 14,79 \\
\hline niv. 4 Groene ruimte & 2.660 & 16,19 \\
\hline Bouw & 3.097 & 18,17 \\
\hline Houtbewerking en woninginrichting & 2.679 & 16,62 \\
\hline Grond-, water-en wegenbouw & 3.078 & 18,87 \\
\hline Fijnmechanische techniek & 2.771 & 16,52 \\
\hline Werktuigbouwkunde & 3.087 & 18,53 \\
\hline Motorvoertuigen en carrosserietechniek & 2.829 & 16,54 \\
\hline Energie- en informatietechniek & 2.862 & 17,08 \\
\hline Energietechniek & 3.023 & 18,02 \\
\hline Informatietechniek & 3.358 & 19,67 \\
\hline Mode en kleding (realisatie) & 2.028 & 13,06 \\
\hline Laboratoriumtechniek & 2.926 & 18,29 \\
\hline Procestechniek & 3.292 & 19,72 \\
\hline Transport \& logistiek & 2.850 & 15,95 \\
\hline Bedrijfsadministratie & 2.300 & 14,07 \\
\hline Commerciële dienstverlening & 2.254 & 13,93 \\
\hline Economisch-juridisch & 2.613 & 15,85 \\
\hline Secretarieel & 2.307 & 14,18 \\
\hline Detailhandel/ambulante handel & 2.271 & 14,29 \\
\hline Groothandel/distributie & 2.525 & 15,27 \\
\hline Horeca, instellingskeuken en contractcatering & 2.919 & 17,88 \\
\hline Toerisme, recreatie en reizen & 2.449 & 15,55 \\
\hline Assistenten gezondheidszorg & 2.360 & 16,20 \\
\hline Facilitaire dienstverlening & 2.233 & 14,75 \\
\hline
\end{tabular}


Tabel B3.8 (vervolg)

Beloning van werkende schoolverlaters

\begin{tabular}{lcc}
\hline Opleidingsrichting & $\begin{array}{c}\text { gemiddeld } \\
\text { bruto maandloon } \\
\text { guldens }\end{array}$ & $\begin{array}{c}\text { gemiddeld } \\
\text { bruto uurloon } \\
\text { guldens }\end{array}$ \\
\hline Sport en bewegen & 2.755 & 20,09 \\
Verpleging en verzorging & 2.190 & 16,40 \\
Uiterlijke verzorging & 1.820 & 12,78 \\
Sociaal-cultureel werker & 2.187 & 18,00 \\
Sociaal-pedagogisch werker & 2.146 & 17,02 \\
Sociaal-juridische dienstverlening & 2.654 & 17,17 \\
\hline Zie ook toelichting bladzijde 32. & &
\end{tabular}

Zie ook toelichting bladzijde 32 . 
Tabel B3.9

Vereist opleidingsniveau voor de huidige functie volgens de werkgever

\begin{tabular}{|c|c|c|c|}
\hline Opleidingsrichting & $\begin{array}{c}\text { lager } \\
\%\end{array}$ & $\begin{array}{l}\text { zelfde } \\
\%\end{array}$ & $\begin{array}{c}\text { hoger } \\
\%\end{array}$ \\
\hline
\end{tabular}

VBO

Landbouw en natuurlijke omgeving

Bouwtechniek

Mechanische techniek

Elektrotechniek

Motorvoertuigentechniek

Consumptieve techniek

Administratie

Verkoop

Handel

Verzorging

Uiterlijke verzorging

$\begin{array}{rrr}35 & 58 & 8 \\ 15 & 80 & 5 \\ 21 & 69 & 10 \\ 4 & 81 & 15 \\ 13 & 78 & 9 \\ 42 & 53 & 5 \\ 24 & 65 & 11 \\ 21 & 71 & 7 \\ 32 & 64 & 5 \\ 30 & 65 & 5 \\ 24 & 65 & 12\end{array}$

BOL niv. 1/2

Oriënteren en schakelen

Werktuigbouwkunde

Energie- en informatietechniek

Brood- en banketbakken

Bedrijfsadministratie

Beveiliging

Secretarieel

Detailhandel/ambulante handel

Horeca, instellingskeuken en contractcatering

Facilitaire dienstverlening

Verpleging en verzorging

BOL niv. $3 / 4$

niv. 3 Plantenteelt

niv. 3 Veehouderij

niv. 3 Bloemschikken

niv. 3 Groene ruimte

niv. 4 Plantenteelt

niv. 4 Veehouderij

niv, 4 Levensmiddelentechnologie

niv. 4 Bloemschikken

niv. 4 Dierenverzorging en veterinaire

ondersteuning

niv. 4 Groene ruimte

Bouw

Houtbewerking en woninginrichting

Grond-, water- en wegenbouw

Fijnmechanische techniek

Werktuigbouwkunde

Motorvoertuigen en carrosserietechniek

Energie- en informatietechniek

Energietechniek

Informatietechniek

Mode en kleding (realisatie)

Laboratoriumtechniek

Procestechniek

Transport \& logistiek

Bedrijfsadministratie

Commerciële dienstverlening

Economisch-juridisch

Secretarieel

Detailhandel/ambulante handel

Groothandel/distributie

Horeca, instellingskeuken en contractcatering

Toerisme, recreatie en reizen

Assistenten gezondheidszorg

Facilitaire dienstverlening

Sport en bewegen

$\begin{array}{rrr}92 & 0 & 8 \\ 44 & 39 & 17 \\ 49 & 38 & 13 \\ 52 & 35 & 13 \\ 47 & 25 & 28 \\ 67 & 7 & 27 \\ 39 & 29 & 32 \\ 52 & 28 & 20 \\ 34 & 37 & 29 \\ 55 & 27 & 18 \\ 59 & 18 & 22\end{array}$

$\begin{array}{rrr}34 & 66 & 0 \\ 62 & 38 & 0 \\ 54 & 46 & 0 \\ 42 & 58 & 0 \\ 18 & 80 & 2 \\ 35 & 65 & 0 \\ 24 & 74 & 2 \\ 39 & 61 & 0 \\ 47 & 47 & 7 \\ 30 & 70 & 0 \\ 18 & 80 & 2 \\ 26 & 73 & 1 \\ 15 & 82 & 3 \\ 12 & 88 & 0 \\ 21 & 77 & 2 \\ 39 & 61 & 0 \\ 26 & 72 & 1 \\ 19 & 77 & 4 \\ 8 & 68 & 24 \\ 37 & 62 & 1 \\ 21 & 75 & 5 \\ 19 & 76 & 5 \\ 19 & 62 & 19 \\ 22 & 76 & 1 \\ 21 & 78 & 1 \\ 13 & 84 & 3 \\ 19 & 78 & 4 \\ 41 & 59 & 1 \\ 13 & 82 & 5 \\ 18 & 79 & 3 \\ 18 & 80 & 2 \\ 15 & 84 & 1 \\ 44 & 56 & 0 \\ 15 & 81 & 5\end{array}$


Tabel B3. 9 (vervolg)

Vereist opleidingsniveau voor de huidige functie volgens de werkgever

\begin{tabular}{llcc}
\hline Opleidingsrichting & $\begin{array}{c}\text { lager } \\
\%\end{array}$ & $\begin{array}{c}\text { zelfde } \\
\%\end{array}$ & $\begin{array}{c}\text { hoger } \\
\%\end{array}$ \\
\hline Verpleging en verzorging & 25 & 75 & 1 \\
Uiterlijke verzorging & 49 & 51 & 0 \\
Sociaal-cultureel werker & 24 & 61 & 15 \\
Sociaal-pedagogisch werker & 26 & 73 & 2 \\
Sociaal-juridische dienstverlening & 25 & 70 & 5 \\
\hline
\end{tabular}

Zie ook toelichting bladzijde 33 . 
Tabel B3.10

Vereiste opleidingsrichting voor de huidige functie volgens de werkgever

\begin{tabular}{lccc}
\hline Opleidingsrichting & $\begin{array}{c}\text { eigen/ } \\
\text { verwante } \\
\text { richting } \\
\%\end{array}$ & $\begin{array}{c}\text { andere } \\
\text { richting }\end{array}$ & $\begin{array}{c}\text { geen } \\
\text { richting }\end{array}$ \\
\hline
\end{tabular}

VBO

IVBO Landbouw en natuurlijke omgeving 34

Landbouw en natuurlijke omgeving 40

Bouwtechniek

Mechanische techniek

Elektrotechniek

Motorvoertuigentechniek

Consumptieve techniek

Administratie

Verkoop

Handel

Verzorging

Uiterlijke verzorging

niv. $1 / 2$

Oriënteren en schakelen

Werktuigbouwkunde

Energie- en informatietechniek

Brood- en banketbakken

Bedrijfsadministratie

Beveiliging

Secretariee

Detailhandel/ambulante handel

$\begin{array}{rr}11 & 55 \\ 7 & 53 \\ 9 & 20 \\ 7 & 35 \\ 11 & 26 \\ 4 & 39 \\ 0 & 58 \\ 6 & 72 \\ 14 & 43 \\ 0 & 55 \\ 2 & 62 \\ 6 & 39\end{array}$

Horeca, instellingskeuken en contractcatering

Facilitaire dienstverlening

Verpleging en verzorging

BOL niv. 3/4

niv. 3 Plantenteelt

niv. 3 Veehouderij

niv. 3 Bloemschikken

niv. 3 Groene ruimte

niv. 4 Plantenteelt

niv. 4 Veehouderij

niv. 4 Levensmiddelentechnologie

niv. 4 Bloemschikken

niv. 4 Dierenverzorging en veterinaire

ondersteuning

niv. 4 Groene ruimte

Bouw

Houtbewerking en woninginrichting

Grond-, water- en wegenbouw

Fijnmechanische techniek

Werktuigbouwkunde

Motorvoertuigen en carrosserietechniek

Energie- en informatietechniek 83

Energietechniek

Informatietechniek

Mode en kleding (realisatie)

Laboratoriumtechniek

Procestechniek

Transport \& logistiek

Bedrijfsadministratie

Commerciële dienstverlening

Economisch-juridisch

Secretarieel

Detailhandel/ambulante handel

Groothandel/distributie

Horeca, instellingskeuken en contractcatering

Toerisme, recreatie en reizen 
Tabel B3.10 (vervolg)

Vereiste opleidingsrichting voor de huidige functie volgens de werkgever

\begin{tabular}{lccc}
\hline Opleidingsrichting & $\begin{array}{c}\text { eigen/ } \\
\text { verwante } \\
\text { richting } \\
\%\end{array}$ & $\begin{array}{c}\text { andere } \\
\text { richting }\end{array}$ & $\begin{array}{c}\text { geen } \\
\text { richting }\end{array}$ \\
\hline Assistenten gezondheidszorg & 89 & 3 & $\%$ \\
Facilitaire dienstverlening & 52 & 8 & 4 \\
Sport en bewegen & 78 & 8 & 14 \\
Verpleging en verzorging & 82 & 3 & 14 \\
Uiterlijke verzorging & 58 & 9 & 33 \\
Sociaal-cultureel werker & 68 & 15 & 17 \\
Sociaal-pedagogisch werker & 71 & 6 & 23 \\
Sociaal-juridische dienstverlening & 54 & 8 & 39 \\
\hline
\end{tabular}

Zie ook toelichting bladzijde 34 . 
Tabel B3.11

Gewenste en feitelijke wekelijkse arbeidsduur van werkende schoolverlaters

\begin{tabular}{|c|c|c|}
\hline Opleidingsrichting & $\begin{array}{l}\text { ste wekelijkse } \\
\text { beidsduur } \\
\text { uren }\end{array}$ & $\begin{array}{c}\text { feitelijke wekelijkse } \\
\text { arbeidsduur } \\
\text { uren }\end{array}$ \\
\hline \multicolumn{3}{|l|}{ VBO } \\
\hline IVBO Landbouw en natuurlijke omgeving & 34,4 & 33,0 \\
\hline Landbouw en natuurlijke omgeving & 36,1 & 32,1 \\
\hline Bouwtechniek & 38,7 & 35,7 \\
\hline Mechanische techniek & 38,0 & 36,3 \\
\hline Elektrotechniek & 37,9 & 31,7 \\
\hline Motorvoertuigentechniek & 41,1 & 34,1 \\
\hline Consumptieve techniek & 36,4 & 33,1 \\
\hline Administratie & 36,2 & 34,2 \\
\hline Verkoop & 33,6 & 29,7 \\
\hline Handel & 37,6 & 33,8 \\
\hline Verzorging & 33,6 & 31,5 \\
\hline Uiterlijke verzorging & 34,8 & 29,9 \\
\hline \multicolumn{3}{|l|}{ BOL niv. $1 / 2$} \\
\hline Oriënteren en schakelen & 37,4 & 36,2 \\
\hline Werktuigbouwkunde & 39,2 & 38,9 \\
\hline Energie- en informatietechniek & 40,6 & 37,3 \\
\hline Brood- en banketbakken & 37,9 & 34,4 \\
\hline Bedrijfsadministratie & 37,2 & 36,7 \\
\hline Beveiliging & 34,8 & 34,7 \\
\hline Secretarieel & 38,6 & 38,7 \\
\hline Detailhandel/ambulante handel & 36,4 & 34,5 \\
\hline Horeca, instellingskeuken en contractcatering & 37,1 & 34,4 \\
\hline Facilitaire dienstverlening & 38,2 & 36,0 \\
\hline Verpleging en verzorging & 35,8 & 31,8 \\
\hline \multicolumn{3}{|l|}{ BOL niv. $3 / 4$} \\
\hline niv. 3 Plantenteelt & 44,3 & 43,6 \\
\hline niv. 3 Veehouderij & 41,7 & 41,2 \\
\hline niv. 3 Bloemschikken & 36,2 & 36,0 \\
\hline niv. 3 Groene ruimte & 39,2 & 37,3 \\
\hline niv. 4 Plantenteelt & 42,9 & 41,5 \\
\hline niv. 4 Veehouderij & 43,2 & 44,2 \\
\hline niv. 4 Levensmiddelentechnologie & 38,2 & 37,9 \\
\hline niv. 4 Bloemschikken & 36,9 & 34,9 \\
\hline niv. 4 Dierenverzorging en veterinaire ondersteuning & 36,3 & 34,2 \\
\hline niv. 4 Groene ruimte & 39,1 & 38,2 \\
\hline Bouw & 41,0 & 39,9 \\
\hline Houtbewerking en woninginrichting & 38,9 & 39,0 \\
\hline Grond-, water- en wegenbouw & 39,0 & 39,2 \\
\hline Fijnmechanische techniek & 40,1 & 38,6 \\
\hline Werktuigbouwkunde & 41,0 & 39,3 \\
\hline Motorvoertuigen en carrosserietechniek & 40,2 & 40,6 \\
\hline Energie- en informatietechniek & 38,6 & 38,9 \\
\hline Energietechniek & 42,2 & 41,1 \\
\hline Informatietechniek & 41,5 & 40,8 \\
\hline Mode en kleding (realisatie) & 36,7 & 36,0 \\
\hline Laboratoriumtechniek & 37,1 & 37,6 \\
\hline Procestechniek & 37,8 & 40,0 \\
\hline Transport \& logistiek & 42,7 & 42,7 \\
\hline Bedrijfsadministratie & 38,9 & 38,7 \\
\hline Commerciële dienstverlening & 37,3 & 38,0 \\
\hline Economisch-juridisch & 37,5 & 38,5 \\
\hline Secretarieel & 37,5 & 38,4 \\
\hline Detailhandel/ambulante handel & 38,8 & 38,2 \\
\hline Groothandel/distributie & 38,9 & 39,6 \\
\hline Horeca, instellingskeuken en contractcatering & 40,3 & 38,3 \\
\hline Toerisme, recreatie en reizen & 38,1 & 37,5 \\
\hline Assistenten gezondheidszorg & 35,9 & 35,3 \\
\hline Facilitaire dienstverlening & 38,0 & 34,9 \\
\hline
\end{tabular}


Tabel B3.11 (vervolg)

Gewenste en feitelijke wekelijkse arbeidsduur van werkende schoolverlaters

\begin{tabular}{lcc} 
Opleidingsrichting & $\begin{array}{c}\text { gewenste wekelijkse } \\
\text { arbeidsduur } \\
\text { uren }\end{array}$ & $\begin{array}{c}\text { feitelijke wekelijkse } \\
\text { arbeidsduur } \\
\text { uren }\end{array}$ \\
\hline Sport en bewegen & 37,5 & 37,3 \\
Verpleging en verzorging & 34,4 & 32,4 \\
Uiterlijke verzorging & 35,7 & 34,6 \\
Sociaal-cultureel werker & 30,3 & 31,2 \\
Sociaal-pedagogisch werker & 34,6 & 31,3 \\
Sociaal-juridische dienstverlening & 35,9 & 36,0 \\
\hline
\end{tabular}

Zie ook toelichting bladzijde 35 . 
Tabel B3.12

Oordeel van de werkende schoolverlaters over de aansluiting tussen de afgesloten opleiding en de huidige functie

\begin{tabular}{|c|c|c|c|c|}
\hline Opleidingsrichting & $\underset{\%}{\text { goed }}$ & $\begin{array}{c}\text { voldoende } \\
\%\end{array}$ & $\underset{\%}{\operatorname{matig}}$ & $\begin{array}{l}\text { slecht } \\
\%\end{array}$ \\
\hline
\end{tabular}

BOL niv. 1/2

Oriënteren en schakelen

Werktuigbouwkunde

Energie- en informatietechniek

Brood- en banketbakken

Bedrijfsadministratie

Beveiliging

Secretarieel

Detailhandel/ambulante handel

Horeca, instellingskeuken en contractcatering

Facilitaire dienstverlening

Verpleging en verzorging

$\begin{array}{rrrr}35 & 32 & 16 & 16 \\ 39 & 26 & 30 & 5 \\ 24 & 34 & 26 & 16 \\ 59 & 29 & 5 & 7 \\ 37 & 33 & 8 & 21 \\ 53 & 33 & 7 & 7 \\ 42 & 41 & 11 & 7 \\ 44 & 33 & 11 & 12 \\ 54 & 33 & 7 & 5 \\ 58 & 19 & 13 & 10 \\ 41 & 21 & 4 & 33\end{array}$

BOL niv. $3 / 4$

niv. 3 Plantenteelt

niv. 3 Veehouderij

niv. 3 Bloemschikken

niv. 3 Groene ruimte

niv. 4 Plantenteelt

niv. 4 Veehouderi

niv. 4 Levensmiddelentechnologie

niv. 4 Bloemschikken

niv. 4 Dierenverzorging en veterinaire ondersteuning

niv. 4 Groene ruimte

Bouw

Houtbewerking en woninginrichting

Grond-, water-en wegenbouw

Fijnmechanische techniek

Werktuigbouwkunde

Motorvoertuigen en carrosserietechniek

Energie- en informatietechniek

Energietechniek

Informatietechniek

Mode en kleding (realisatie)

Laboratoriumtechniek

Procestechniek

Transport \& logistiek

Bedrijfsadministratie

Commerciële dienstverlening

Economisch-juridisch

Secretariee

Detailhandel/ambulante handel

Groothandel/distributie

Horeca, instellingskeuken en contractcatering

Toerisme, recreatie en reizen

Assistenten gezondheidszorg

Facilitaire dienstverlening

Sport en bewegen

Verpleging en verzorging

Uiterlijke verzorging

Sociaal-cultureel werker

Sociaal-pedagogisch werker

Sociaal-juridische dienstverlening

\begin{tabular}{|c|c|c|}
\hline 49 & 40 & 5 \\
\hline 45 & 33 & 7 \\
\hline 51 & 24 & 13 \\
\hline 45 & 36 & 3 \\
\hline 55 & 26 & 11 \\
\hline 39 & 33 & 15 \\
\hline 14 & 42 & 30 \\
\hline 63 & 19 & 2 \\
\hline 40 & 27 & 7 \\
\hline 20 & 52 & 19 \\
\hline 39 & 39 & 15 \\
\hline 43 & 43 & 9 \\
\hline 52 & 30 & 8 \\
\hline 33 & 37 & 18 \\
\hline 38 & 43 & 15 \\
\hline 41 & 31 & 17 \\
\hline 37 & 40 & 16 \\
\hline 31 & 50 & 15 \\
\hline 43 & 36 & 21 \\
\hline 39 & 33 & 13 \\
\hline 50 & 24 & 14 \\
\hline 33 & 35 & 20 \\
\hline 19 & 56 & 19 \\
\hline 33 & 46 & 14 \\
\hline 38 & 43 & 8 \\
\hline 41 & 28 & 21 \\
\hline 40 & 43 & 15 \\
\hline 42 & 39 & 11 \\
\hline 33 & 46 & 14 \\
\hline 47 & 41 & 9 \\
\hline 35 & 38 & 17 \\
\hline 61 & 27 & 7 \\
\hline 37 & 33 & 14 \\
\hline 47 & 31 & 10 \\
\hline 56 & 32 & 8 \\
\hline 48 & 25 & 11 \\
\hline 36 & 36 & 15 \\
\hline 46 & 31 & 10 \\
\hline 29 & 45 & 20 \\
\hline
\end{tabular}

Zie ook toelichting bladzijde 36 . 
Tabel B3.13

Percentage werkende schoolverlaters dat op zoek is naar een andere baan

Opleidingsrichting

VBO

Landbouw en natuurlijke omgeving

15

Bouwtechniek

Mechanische techniek

Elektrotechniek

Motorvoertuigentechniek

Consumptieve techniek

Administratie

Verkoop

Handel

Verzorging

Uiterlijke verzorging

BOL niv. $1 / 2$

Oriënteren en schakelen

Werktuigbouwkunde

Energie- en informatietechniek

Brood- en banketbakken

Bedrijfsadministratie

Beveiliging

Secretariee

Detailhandel/ambulante handel

Horeca, instellingskeuken en contractcatering

Facilitaire dienstverlening

Verpleging en verzorging

BOL niv. $3 / 4$

niv. 3 Plantenteelt

niv. 3 Veehouderij

niv. 3 Bloemschikken

niv. 3 Groene ruimte

niv. 4 Plantenteelt

niv. 4 Veehouderij

niv. 4 Levensmiddelentechnologie

niv. 4 Bloemschikken

niv. 4 Dierenverzorging en veterinaire ondersteuning

niv. 4 Groene ruimte

Bouw

Houtbewerking en woninginrichting

Grond-, water-en wegenbouw

Fijnmechanische techniek

Werktuigbouwkunde

Motorvoertuigen en carrosserietechniek

Energie- en informatietechniek

Energietechniek

Informatietechniek

Mode en kleding (realisatie)

Laboratoriumtechniek

Procestechniek

Transport \& logistiek

Bedrijfsadministratie

Commerciële dienstverlening

Economisch-juridisch

Secretarieel

Detailhandel/ambulante handel

Groothandel/distributie

Horeca, instellingskeuken en contractcatering

Toerisme, recreatie en reizen

Assistenten gezondheidszorg

Facilitaire dienstverlening

Sport en bewegen

Verpleging en verzorging

Uiterlijke verzorging 
Tabel B3.13 (vervolg)

Percentage werkende schoolverlaters dat op zoek is naar een andere baan

Opleidingsrichting

Sociaal-cultureel werker

Sociaal-pedagogisch werker

Sociaal-juridische dienstverlening

Zie ook toelichting bladzijde 37 . 
Tabel B3.14

Deelname aan een cursus of bedrijfsopleiding door werkende schoolverlaters

Opleidingsrichting

BOL niv. $1 / 2$

Oriënteren en schakelen 38

Werktuigbouwkunde 46

Energie- en informatietechniek 51

Brood- en banketbakken 12

Bedrijfsadministratie

$\begin{array}{lr}\text { Beveiliging } & 40 \\ & 30\end{array}$

27

Horeca, instellingskeuken en contractcatering 13

Facilitaire dienstverlening 18

Verpleging en verzorging 16

BOL niv. $3 / 4$

niv. 3 Plantenteelt 20

niv. 3 Veehouderij 33

niv. 3 Bloemschikken 12

niv. 3 Groene ruimte 16

niv. 4 Plantenteelt 38

niv. 4 Veehouderij 37

niv. 4 Levensmiddelentechnologie 41

niv. 4 Bloemschikken $\quad 16$

niv. 4 Dierenverzorging en veterinaire ondersteuning 36

niv. 4 Groene ruimte 37

Bouw $\quad 57$

Houtbewerking en woninginrichting $\quad 30$

Grond-, water- en wegenbouw $\quad 57$

Fijnmechanische techniek 33

Werktuigbouwkunde 63

$\begin{array}{ll}\text { Motorvoertuigen en carrosserietechniek } & 57 \\ & 56\end{array}$

Energie- en informatietechniek 56

$\begin{array}{ll}\text { Energietechniek } & 62\end{array}$

Informatietechniek 49

Mode en kleding (realisatie) $\quad 30$

Laboratoriumtechniek 43

Procestechniek 41

Transport \& logistiek $\quad 40$

Bedrijfsadministratie $\quad 54$

$\begin{array}{ll}\text { Commerciële dienstverlening } & 60\end{array}$

Economisch-juridisch $\quad 45$

45

Detailhandel/ambulante handel $\quad 44$

Groothandel/distributie $\quad 52$

Horeca, instellingskeuken en contractcatering 33

Toerisme, recreatie en reizen $\quad 54$

Assistenten gezondheidszorg $\quad 40$

$\begin{array}{ll}\text { Facilitaire dienstverlening } & 61\end{array}$

Sport en bewegen 36

Verpleging en verzorging 18

Uiterlijke verzorging $\quad 38$

28

Sociaal-pedagogisch werker $\quad 25$

Sociaal-juridische dienstverlening 48

Zie ook toelichting bladzijde 38 . 
Tabel B3.15

Belangrijkste cursussen of bedrijfsopleidingen waaraan werkende schoolverlaters deelnemen

BOL niv. 1/2 Energie- en informatietechniek

Techniek

Telecommunicatie/datacommunicatie

Bedrijfstechniek, technische bedrijfsvoering

Energie- en informatietechniek

Elektrische energietechniek

Elektronica algemeen/radio-TV

Weg-, railvervoer

Detailhandel (incl. middenstandsdiploma)

BOL niv. 1/2 Bedrijfsadministratie

Computer en informatica

Bedrijfsadministratie, accountancy

Secretarieel (incl. tekstverwerking, steno)

Administratief

Marketing, reclame

Detailhandel (incl. middenstandsdiploma)

BOL niv. 1/2 Detailhandel/ambulante handel

Detailhandel (incl. middenstandsdiploma)

Bedrijfstechniek, technische bedrijfsvoering

Commercieel

Bedrijfskunde, management, efficiency

Natuurkunde, materiaalkunde

BOL niv. 3/4 Veehouderij

Veeteelt

Bouwkunde

Bedrijfstechniek, technische bedrijfsvoering

Landbouw

Onderwijs

Bedrijfskunde, management, efficiency

Detailhandel (incl. middenstandsdiploma)

BOL niv. 3/4 Plantenteelt (en handel)

Landbouw

Marketing, reclame

Scheikunde

Bedrijfstechniek, technische bedrijfsvoering

Bedrijfskunde, management, efficiency

Gezondheidszorg

Veeteelt

Tuinbouw

Bedrijfsadministratie, accountancy

Communicatieve vaardigheden

$\mathrm{BB}$, bedrijfszelfbescherming

BOL niv. 3/4 Veehouderij

Veeteelt

Algemene en bedrijfseconomie

Bedrijfskunde, management, efficiency

Bedrijfsadministratie, accountancy

Commercieel

Bedriifstechniek, technische bedrijfsvoering

Detailhandel (incl. middenstandsdiploma)

Weg-, railvervoer 
Tabel B3.15 (vervolg)

Belangrijkste cursussen of bedrijfsopleidingen waaraan werkende schoolverlaters deelnemen

BOL niv. 3/4 Levensmiddelentechnologie

Bedrijfstechniek, technische bedrijfsvoering

Techniek

Bedrijfskunde, management, efficiency

Veeteelt

Computer en informatica

Weg-, railvervoer

Gezondheidszorg

Leraren metaal-, elektrotechn., werktuig

Secretarieel (incl. tekstverwerking, steno)

Biologie

Verpleging

15

11

8

6

6

5

BOL niv. 3/4 Bouw

Bouwkunde

Detailhandel (incl. middenstandsdiploma)

Bedrijfstechniek, technische bedrijfsvoering

Computer en informatica

Bedrijfskunde, management, efficiency

$\mathrm{BB}$, bedrijfszelfbescherming

Commercieel

BOL niv. 3/4 Houtbewerking en woninginrichting

Computer en informatica

Kunst en cultuur

Techniek

Bedrijfstechniek, technische bedrijfsvoering

Commercieel

BOL niv. 3/4 Grond-, water- en wegenbouw

Weg- en waterbouwkunde, landmeetkunde

Computer en informatica

Bedrijfstechniek, technische bedrijfsvoering

Detailhandel (incl. middenstandsdiploma)

Commercieel

BOL niv. 3/4 Werktuigbouwkunde

Bedrijfstechniek, technische bedrijfsvoering

Techniek

Werktuigbouwkunde

Computer en informatica

Bedrijfskunde, management, efficiency

Elektrotechniek

Metaalbewerking

BOL niv. $3 / 4$ Motorvoertuigen en carrosserietechniek Werktuigbouwkunde

Techniek

Computer en informatica

Commercieel

Elektrotechniek

Weg-, railvervoer

Marketing, reclame

BOL niv. 3/4 Energie- en informatietechniek

Computer en informatica

Elektrotechniek

Bedrijfstechniek, technische bedrijfsvoering

Techniek

Telecommunicatie/datacommunicatie

Elektrische energietechniek

Elektronica algemeen/radio-TV

Bedrijfskunde, management, efficiency 
Tabel B3.15 (vervolg)

Belangrijkste cursussen of bedrijfsopleidingen waaraan werkende schoolverlaters deelnemen

BOL niv. 3/4 Mode en kleding

Kunst en cultuur

Techniek

Computer en informatica

Marketing, reclame

Commercieel

BOL niv. 3/4 Laboratoriumtechniek

Techniek

Gezondheidszorg

Laboratoriumpersoneel

Detailhandel (incl. middenstandsdiploma)

Scheikunde

Biologie

Geneeskunde

Uiterlijke verzorging

Germaanse talen

BOL niv. $3 / 4$ Bedrijfsadministratie

Bedrijfsadministratie, accountancy

Computer en informatica

Verzekeringswezen

Secretarieel (incl. tekstverwerking, steno)

Geld- en bankzaken

Administratief

Detailhandel (incl. middenstandsdiploma)

BOL niv. 3/4 Commerciële dienstverlening

Verzekeringswezen

Geld- en bankzaken

Computer en informatica

BOL niv. 3/4 Economisch-juridisch

Recht

Bedrijfskunde, management, efficiency

Verzekeringswezen

Computer en informatica

Bedrijfsadministratie, accountancy

Detailhandel (incl. middenstandsdiploma)

Geld- en bankzaken

Algemene en bedrijfseconomie

BOL niv. 3/4 Secretarieel

Secretarieel (incl. tekstverwerking, steno)

Computer en informatica

Germaanse talen

Verzekeringswezen

Marketing, reclame

Economie

Bedrijfsadministratie, accountancy

BOL niv. 3/4 Detailhandel/ambulante handel

Detailhandel (incl. middenstandsdiploma)

Bedrijfskunde, management, efficiency

Commercieel

Marketing, reclame 
Tabel B3.15 (vervolg)

Belangrijkste cursussen of bedrijfsopleidingen waaraan werkende schoolverlaters deelnemen

BOL niv. 3/4 Groothandel/distributie

Verzekeringswezen

Geld- en bankzaken

Commercieel

Marketing, reclame

Germaanse talen

Secretarieel (incl. tekstverwerking, steno)

BOL niv. 3/4 Horeca, instellingskeuken en contractcatering

Horeca

Bedrijfskunde, management, efficiency

Commercieel

Gezondheidszorg

Romaanse talen

BOL niv. 3/4 Toerisme, recreatie en reizen

Toerisme

Commercieel

Verzekeringswezen

Luchtvaart

Secretarieel (incl. tekstverwerking, steno)

Computer en informatica

Geld- en bankzaken

Bedrijfskunde, management, efficiency

Marketing, reclame

\section{5
5
5}

BOL niv. 3/4 Assistenten gezondheidszorg

Farmacie

Gezondheidszorg

Tandheelkunde

Detailhandel (incl. middenstandsdiploma)

BOL niv. 3/4 Facilitaire dienstverlening Detailhandel (incl. middenstandsdiploma)

Geld- en bankzaken

Bedrijfstechniek, technische bedrijfsvoering

Bedrijfskunde, management, efficiency

Economie

Public relations

Gedrag en maatschappij

Marketing, reclame

Horeca

$\mathrm{BB}$, bedrijfszelfbescherming

\section{BOL niv. 3/4 Sport en bewegen}

Onderwijs

Secretarieel (incl. tekstverwerking, steno)

Marketing, reclame

Detailhandel (incl. middenstandsdiploma)

Bedrijfstechniek, technische bedrijfsvoering

Leraren (para)med. vakken en pers./soc.

Horeca

Algemeen 
Tabel B3.15 (vervolg)

Belangrijkste cursussen of bedrijfsopleidingen waaraan werkende schoolverlaters deelnemen

$\%$

BOL niv. 3/4 Verpleging en verzorging

Verpleging

Gezondheidszorg

Bejaardenverzorging

Computer en informatica

Communicatieve vaardigheden

Sociale verzorging

Sociaal werk

Bedrijfskunde, management, efficiency

9

7

21
9
7
7
5
5
5
5

5

BOL niv. 3/4 Uiterlijke verzorging

Uiterlijke verzorging

Detailhandel (incl. middenstandsdiploma)

Farmacie

Marketing, reclame

BOL niv. 3/4 Sociaal-pedagogisch werker

Gezondheidszorg

Bedrijfskunde, management, efficiency

Maatschappelijk werk

Communicatieve vaardigheden

Secretarieel (incl. tekstverwerking, steno)

Kinderverzorging

BOL niv. 3/4 Sociaal-juridische dienstverlening

Computer en informatica

Communicatieve vaardigheden

Recht

Verzekeringswezen

Sociaal werk

Personeelswerk

Bedrijfsadministratie, accountancy

Maatschappelijk werk

Zie ook toelichting bladzijde 42. De gepresenteerde percentages in deze tabel zijn soms gebaseerd op zeer kleine aantallen. 


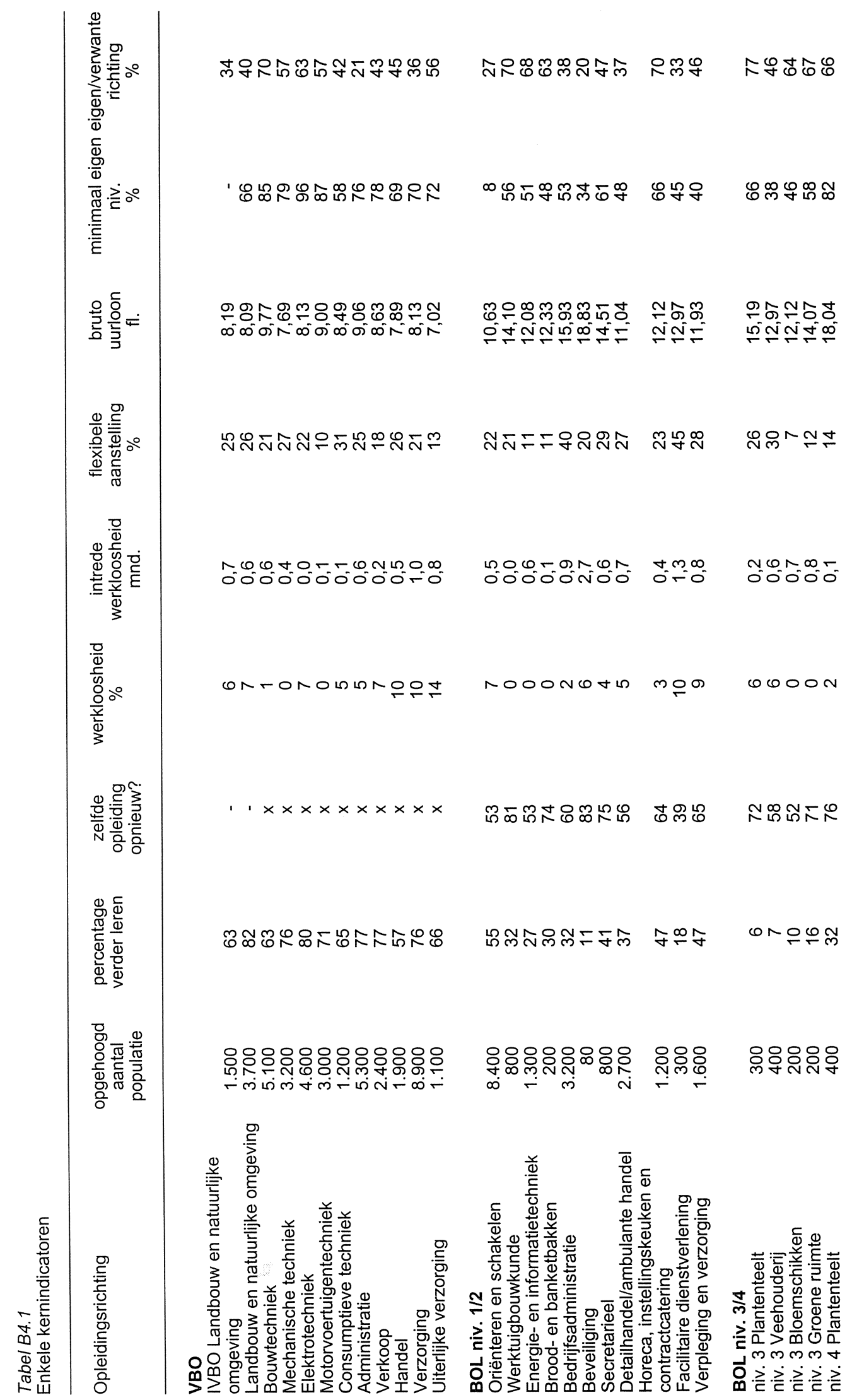




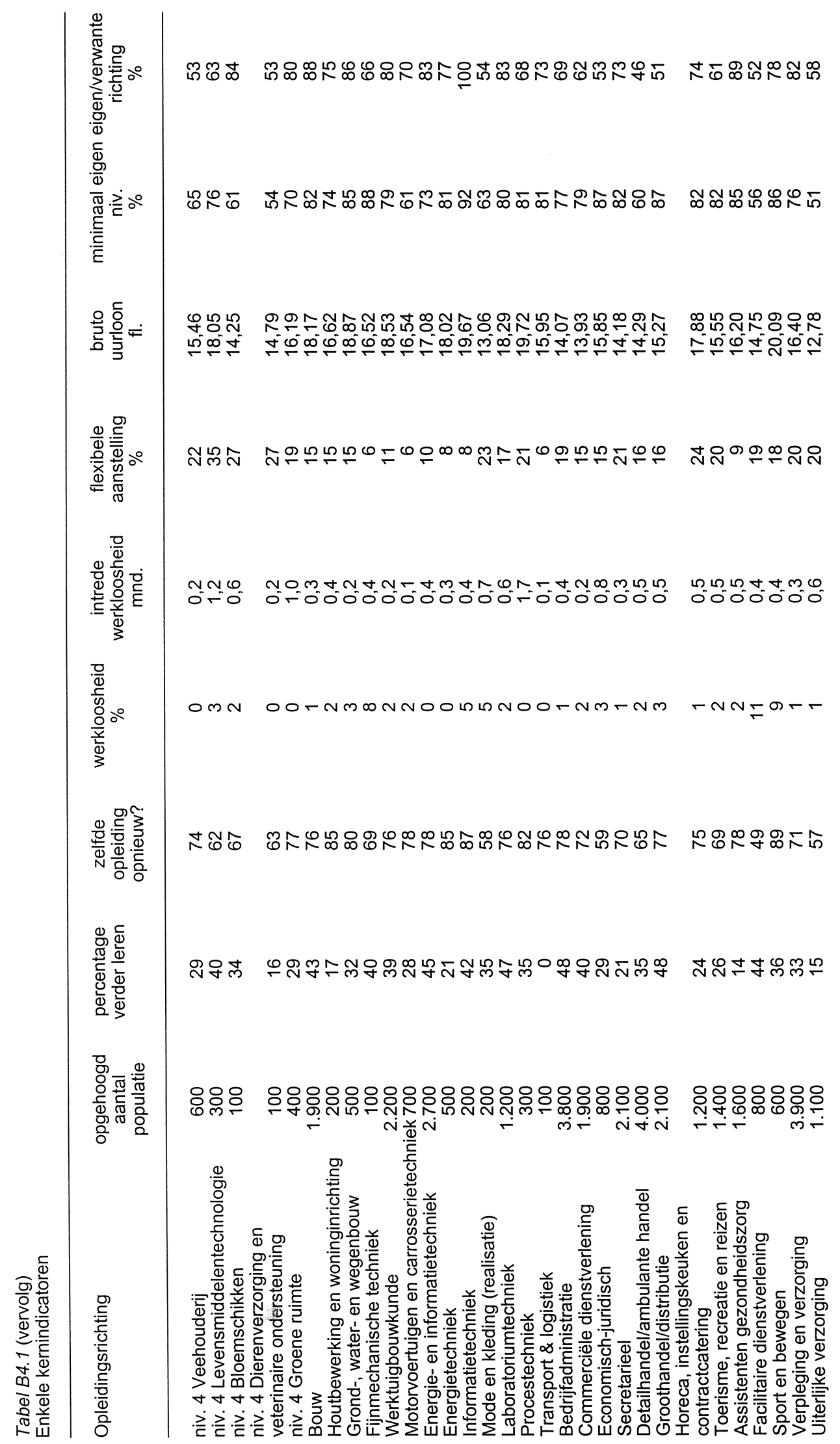




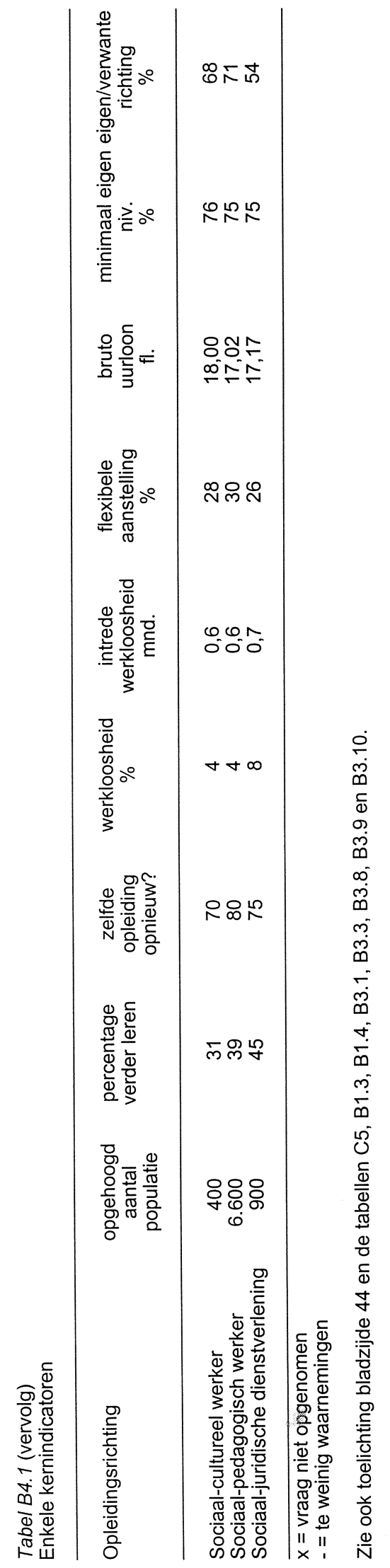


C. Respons 

Tabel C.1

Ongewogen aantal respondenten verbijzonderd naar bestemming per opleidingssector

\begin{tabular}{|c|c|c|c|c|c|c|c|}
\hline Opleidingssector & studie & BBL & $\begin{array}{r}\text { betaald } \\
\text { werk }\end{array}$ & werkloos & anders & onbekend & totaal \\
\hline \multicolumn{8}{|l|}{ AVO } \\
\hline MAVO & 1.338 & 103 & 129 & 13 & 36 & 7 & 1.626 \\
\hline HAVO & 1.495 & 31 & 136 & 4 & 27 & 9 & 1.702 \\
\hline VWO & 1.400 & 4 & 50 & 3 & 16 & 9 & 1.482 \\
\hline Totaal & 4.233 & 138 & 315 & 20 & 79 & 25 & 4.810 \\
\hline \multicolumn{8}{|l|}{ VBO } \\
\hline IVBO & 164 & 92 & 120 & 6 & 9 & 5 & 396 \\
\hline landbouw & 362 & 81 & 83 & 4 & 17 & 4 & 551 \\
\hline techniek & 160 & 105 & 102 & 4 & 5 & 6 & 382 \\
\hline economie & 187 & 22 & 73 & 4 & 3 & 1 & 290 \\
\hline gezondheidszorg & 225 & 42 & 67 & 6 & 12 & 5 & 357 \\
\hline Totaal & 1.098 & 342 & 445 & 24 & 46 & 21 & 1.976 \\
\hline
\end{tabular}

BOL niv. $1 / 2$

oriënteren en schakelen

landbouw

techniek

economie

gezondheidszorg

Totaal

$\begin{array}{rr}53 & \\ 12 & \\ 30 & 30 \\ 162 & 45 \\ 64 & 15 \\ 321 & 102\end{array}$

$3 \quad 38$

$\begin{array}{rr}9 & 33 \\ 30 & 126\end{array}$

$45 \quad 324$

$15 \quad 98$

98
619

4
3
2
12
4
25

$\begin{array}{rrr}3 & 0 & 101 \\ 1 & 0 & 58 \\ 3 & 1 & 192 \\ 12 & 7 & 562 \\ 8 & 2 & 191 \\ 27 & 10 & 1.104\end{array}$

BOL niv. $3 / 4$

landbouw

techniek

economie

gezondheidszorg

gedrag en maatschappij

Totaal

144

669

892

326

515

2.546

$\begin{array}{rr}8 & 483 \\ 22 & 1.056 \\ 33 & 1.622 \\ 64 & 1.022 \\ 35 & 813 \\ 162 & 4.996\end{array}$

$\begin{array}{rr}7 & 9 \\ 17 & 26 \\ 24 & 24 \\ 17 & 26 \\ 22 & 37 \\ 87 & 122\end{array}$

$\begin{array}{rr}4 & 655 \\ 7 & 1.797 \\ 10 & 2.605 \\ 11 & 1.466 \\ 11 & 1.433 \\ 43 & 7.956\end{array}$

HBO

landbouw

onderwijs

techniek

economie

gezondheidszorg

114

181

387

gedrag en maatschappij

512

kunst en cultuur

112

Totaal

190
72

1.568

$\begin{array}{lr}0 & 772 \\ 0 & 1.888 \\ 0 & 2.952 \\ 0 & 3.614 \\ 0 & 1.404 \\ 0 & 1.775 \\ 0 & 649 \\ 0 & 13.054\end{array}$

$\begin{array}{rrrr}29 & 14 & 4 & 933 \\ 64 & 36 & 69 & 2.238 \\ 52 & 35 & 69 & 3.495 \\ 76 & 47 & 78 & 4.327 \\ 24 & 26 & 42 & 1.608 \\ 80 & 58 & 41 & 2.144 \\ 45 & 103 & 377 & 1.246 \\ 370 & 319 & 680 & 15.991\end{array}$

WO

landbouw

techniek

economie

gezondheidszorg

gedrag en maatschappij

taal en cultuur

recht en openbare orde

natuurwetenschappen

Totaal

11
15
16
16
51
93
30
30
270

0499

15.991

Totaal

10.036

0
0
0
0
0
0
0
0
0

499
1.812

1.943

1.014

1.946

1.469

1.337

1.004

11.024

22
19
25
19
82
78
31
27
304

$\begin{array}{rrr}11 & 2 & 545 \\ 4 & 8 & 1.858 \\ 4 & 3 & 1.991 \\ 7 & 4 & 1.060 \\ 50 & 9 & 2.138 \\ 31 & 13 & 1.684 \\ 10 & 6 & 1.414 \\ 8 & 3 & 1.072 \\ 137 & 202 & 11.937 \\ 730 & 981 & 43.774\end{array}$

Toelichting

De aantallen in deze tabel betreffen het feitelijke aantal respondenten waarvan de gegevens in de analyses zijn opgenomen. 
Tabel C. 2

Naar landelijke populatie gewogen aantal schoolverlaters verbijzonderd naar bestemming per opleidingssector

\begin{tabular}{|c|c|c|c|c|c|c|c|}
\hline Opleidingssector & studie & $\mathrm{BBL}$ & $\begin{array}{r}\text { betaald } \\
\text { werk }\end{array}$ & werkloos & anders & onbekend & totaal \\
\hline $\begin{array}{l}\text { AVO } \\
\text { MAVO } \\
\text { HAVO } \\
\text { VWO } \\
\text { Totaal }\end{array}$ & $\begin{array}{r}43.300 \\
32.900 \\
26.600 \\
102.700\end{array}$ & $\begin{array}{r}3.100 \\
700 \\
70 \\
3.800\end{array}$ & $\begin{array}{r}4.300 \\
2.900 \\
900 \\
8.200\end{array}$ & $\begin{array}{r}400 \\
80 \\
50 \\
500\end{array}$ & $\begin{array}{r}1.100 \\
600 \\
300 \\
2.000\end{array}$ & $\begin{array}{l}200 \\
200 \\
200 \\
500\end{array}$ & $\begin{array}{r}52.300 \\
37.300 \\
28.000 \\
117.700\end{array}$ \\
\hline $\begin{array}{l}\text { VBO } \\
\text { IVBO } \\
\text { landbouw } \\
\text { techniek } \\
\text { economie } \\
\text { gezondheidszorg } \\
\text { Totaal }\end{array}$ & $\begin{array}{r}3.200 \\
2.500 \\
7.600 \\
6.300 \\
6.800 \\
26.400\end{array}$ & $\begin{array}{r}1.600 \\
600 \\
4.800 \\
700 \\
1.300 \\
9.000\end{array}$ & $\begin{array}{r}2.000 \\
500 \\
4.700 \\
2.300 \\
2.200 \\
11.700\end{array}$ & $\begin{array}{r}40 \\
30 \\
200 \\
100 \\
200 \\
500\end{array}$ & $\begin{array}{r}200 \\
100 \\
200 \\
100 \\
400 \\
1.000\end{array}$ & $\begin{array}{r}100 \\
30 \\
200 \\
30 \\
200 \\
600\end{array}$ & $\begin{array}{r}7.200 \\
3.800 \\
17.700 \\
9.600 \\
10.900 \\
49.200\end{array}$ \\
\hline $\begin{array}{l}\text { BOL niv. } 1 / 2 \\
\text { oriënteren en schakelen } \\
\text { landbouw } \\
\text { techniek } \\
\text { economie } \\
\text { gezondheidszorg } \\
\text { Totaal }\end{array}$ & $\begin{array}{r}4.400 \\
100 \\
500 \\
2.400 \\
700 \\
8.000\end{array}$ & $\begin{array}{r}300 \\
70 \\
500 \\
600 \\
200 \\
1.600\end{array}$ & $\begin{array}{r}3.200 \\
200 \\
2.300 \\
4.700 \\
1.200 \\
11.600\end{array}$ & $\begin{array}{r}300 \\
20 \\
30 \\
200 \\
60 \\
600\end{array}$ & $\begin{array}{r}300 \\
0 \\
70 \\
200 \\
90 \\
600\end{array}$ & $\begin{array}{r}0 \\
0 \\
0 \\
100 \\
30 \\
100\end{array}$ & $\begin{array}{r}8.400 \\
400 \\
3.400 \\
8.100 \\
2.200 \\
22.600\end{array}$ \\
\hline $\begin{array}{l}\text { BOL niv. } \mathbf{3 / 4} \\
\text { landbouw } \\
\text { techniek } \\
\text { economie } \\
\text { gezondheidszorg } \\
\text { gedrag en maatschappij } \\
\text { Totaal }\end{array}$ & $\begin{array}{r}600 \\
4.200 \\
6.100 \\
1.900 \\
2.900 \\
15.700\end{array}$ & $\begin{array}{r}50 \\
100 \\
200 \\
300 \\
200 \\
900\end{array}$ & $\begin{array}{r}2.300 \\
6.500 \\
10.700 \\
5.500 \\
4.500 \\
29.500\end{array}$ & $\begin{array}{r}30 \\
90 \\
200 \\
100 \\
100 \\
600\end{array}$ & $\begin{array}{r}50 \\
100 \\
200 \\
100 \\
200 \\
700\end{array}$ & $\begin{array}{r}20 \\
60 \\
50 \\
50 \\
60 \\
200\end{array}$ & $\begin{array}{r}3.000 \\
11.200 \\
17.400 \\
8.000 \\
7.900 \\
47.600\end{array}$ \\
\hline $\begin{array}{l}\text { HBO } \\
\text { landbouw } \\
\text { onderwijs } \\
\text { techniek } \\
\text { economie } \\
\text { gezondheidszorg } \\
\text { gedrag en maatschappij } \\
\text { kunst en cultuur } \\
\text { Totaal }\end{array}$ & $\begin{array}{r}200 \\
600 \\
1.200 \\
1.400 \\
200 \\
500 \\
200 \\
4.300\end{array}$ & $\begin{array}{l}x \\
x \\
x \\
x \\
x \\
x \\
x \\
x\end{array}$ & $\begin{array}{r}1.500 \\
5.900 \\
8.700 \\
9.700 \\
3.200 \\
4.200 \\
1.600 \\
34.900\end{array}$ & $\begin{array}{r}60 \\
200 \\
100 \\
200 \\
60 \\
200 \\
200 \\
1.000\end{array}$ & $\begin{array}{r}30 \\
100 \\
100 \\
100 \\
60 \\
100 \\
400 \\
1.000\end{array}$ & $\begin{array}{r}10 \\
200 \\
200 \\
200 \\
90 \\
100 \\
1100 \\
1900\end{array}$ & $\begin{array}{r}1.800 \\
7.100 \\
10.400 \\
11.600 \\
3.600 \\
5.100 \\
3.500 \\
43.000\end{array}$ \\
\hline $\begin{array}{l}\text { WO } \\
\text { landbouw } \\
\text { techniek } \\
\text { economie } \\
\text { gezondheidszorg } \\
\text { gedrag en maatschappij } \\
\text { taal en cultuur } \\
\text { recht en openbare orde } \\
\text { natuurwetenschappen } \\
\text { Totaal }\end{array}$ & $\begin{array}{r}20 \\
30 \\
30 \\
30 \\
100 \\
200 \\
60 \\
60 \\
600\end{array}$ & $\begin{array}{l}x \\
x \\
x \\
x \\
x \\
x \\
x \\
x \\
x\end{array}$ & $\begin{array}{r}800 \\
3.300 \\
4.400 \\
2.300 \\
3.800 \\
3.200 \\
3.000 \\
1.900 \\
22.700\end{array}$ & $\begin{array}{r}40 \\
30 \\
60 \\
50 \\
200 \\
200 \\
70 \\
50 \\
600\end{array}$ & $\begin{array}{r}20 \\
10 \\
10 \\
20 \\
100 \\
70 \\
30 \\
20 \\
300\end{array}$ & $\begin{array}{r}0 \\
10 \\
10 \\
10 \\
10 \\
30 \\
20 \\
10 \\
400\end{array}$ & $\begin{array}{r}900 \\
3.300 \\
4.500 \\
2.400 \\
4.200 \\
3.700 \\
3.200 \\
2.000 \\
24.600\end{array}$ \\
\hline Totaal & 157.700 & 15.300 & 118.500 & 3.800 & 5.600 & 3700 & 304.800 \\
\hline
\end{tabular}

$\mathrm{x}=$ antwoordcategorie niet opgenomen

Toelichting

De aantallen in deze tabel zijn zodanig opgehoogd dat een representatief beeld wordt gegeven van de totale populatie van schoolverlaters. 
Tabel C.3

Responspercentage per opleidingssector

Opleidingssector

AVO

MAVO

HAVO

VWO

Totaal

66
60

VBO

IVBO

landbouw

techniek

economie

gezondheidszorg

Totaal

BOL niv. 1/2

oriënteren en schakelen

landbouw

techniek

economie

gezondheidszorg

Totaal

5
8
6
0

BOL niv. 3/4

landbouw

techniek

economie

gezondheidszorg

gedrag en maatschappij

Totaal

landbouw

onderwijs

techniek

economie

gezondheidszorg

en maatschappij

kunst en cultuur

Totaal

Wo

landbouw

techniek

economie

gezondheidszorg

gedrag en maatschappij

taal en cultuur

recht en openbare orde

natuurwetenschappen

49

Totaal

Totaal

50

\section{Toelichting}

De responspercentages geven een beeld van het aandeel van de uitgezette vragenlijsten dat bruikbaar retour is gekomen. De responspercentages van het WO hebben betrekking op 9 universiteiten. 


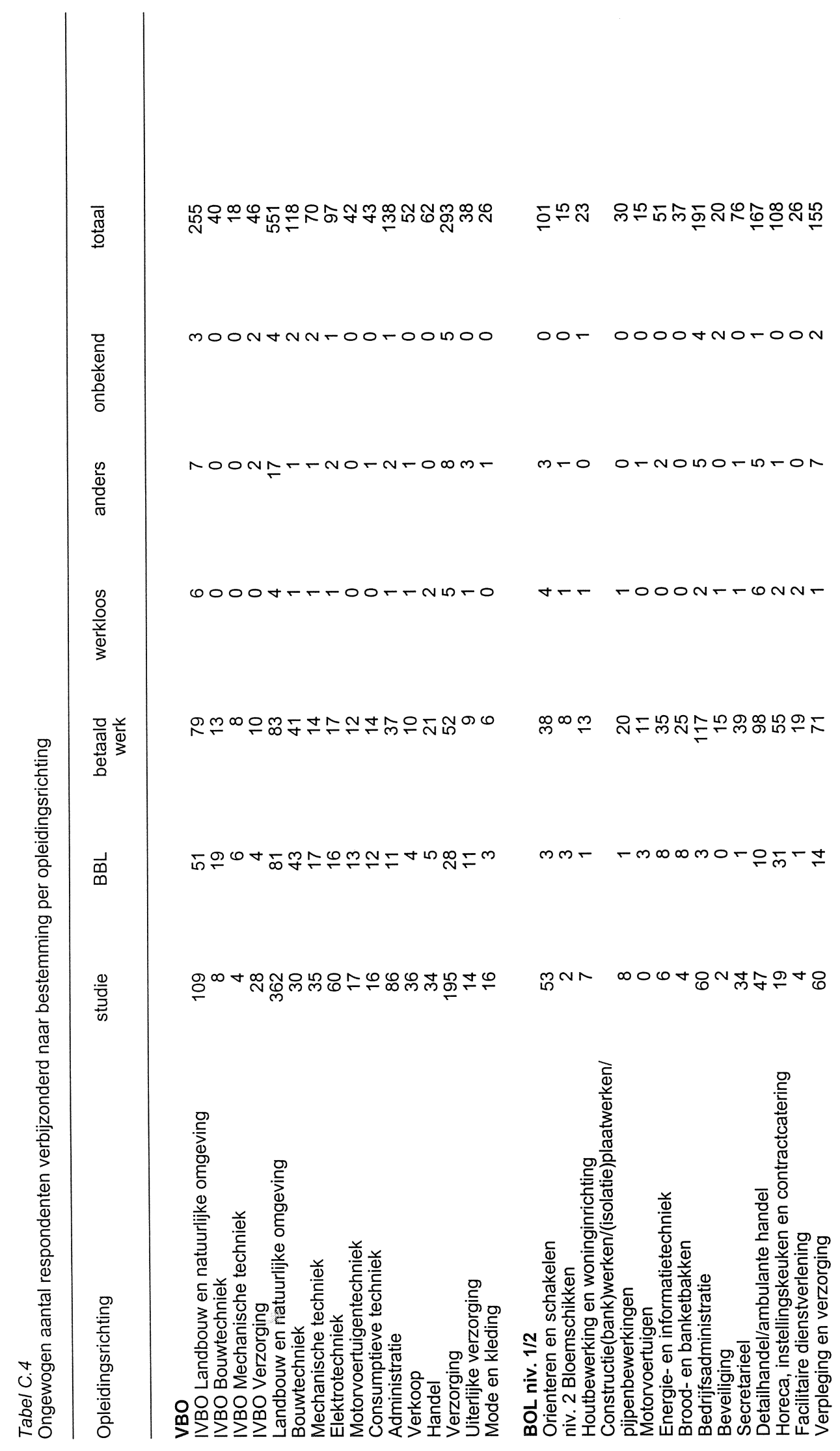




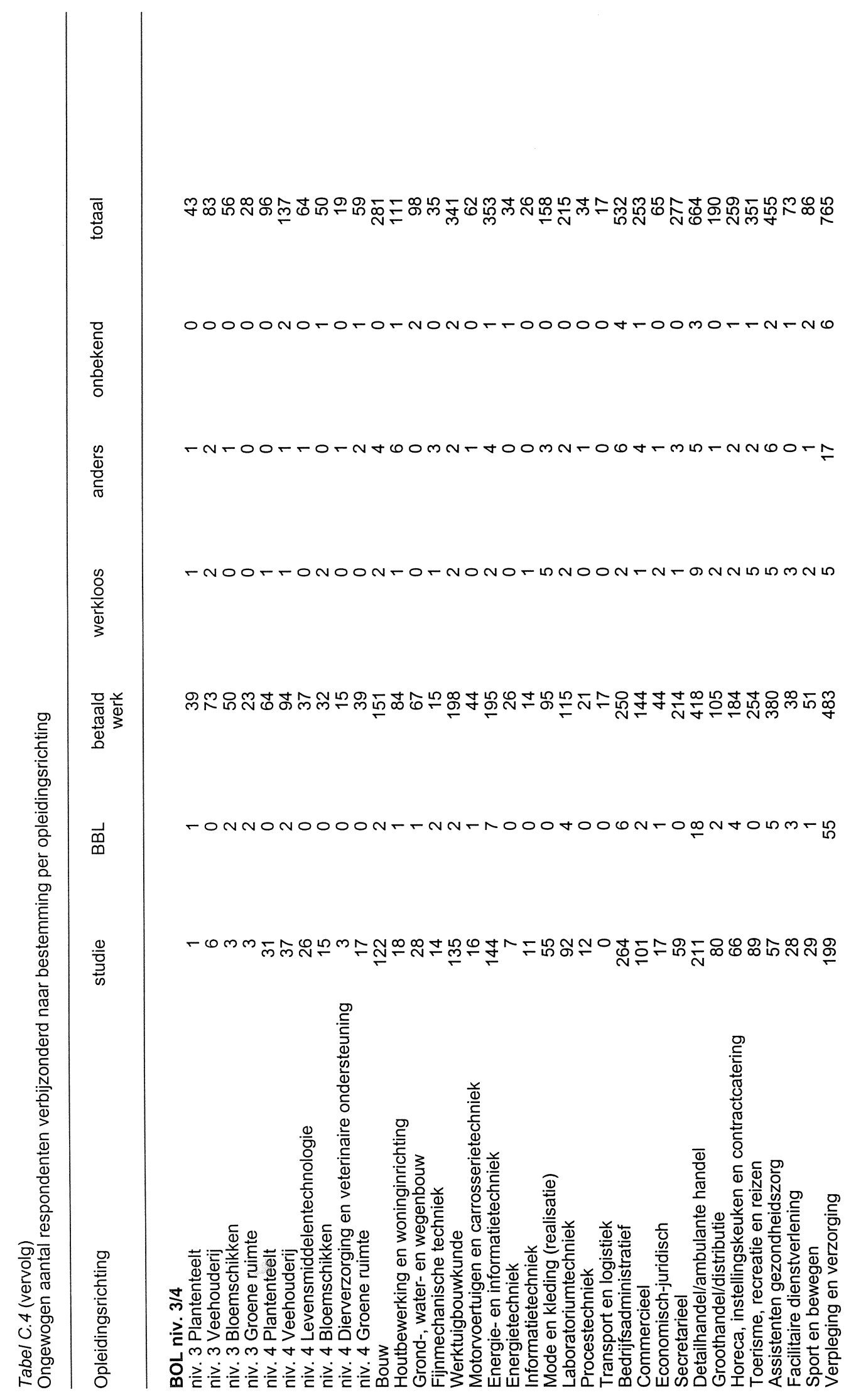




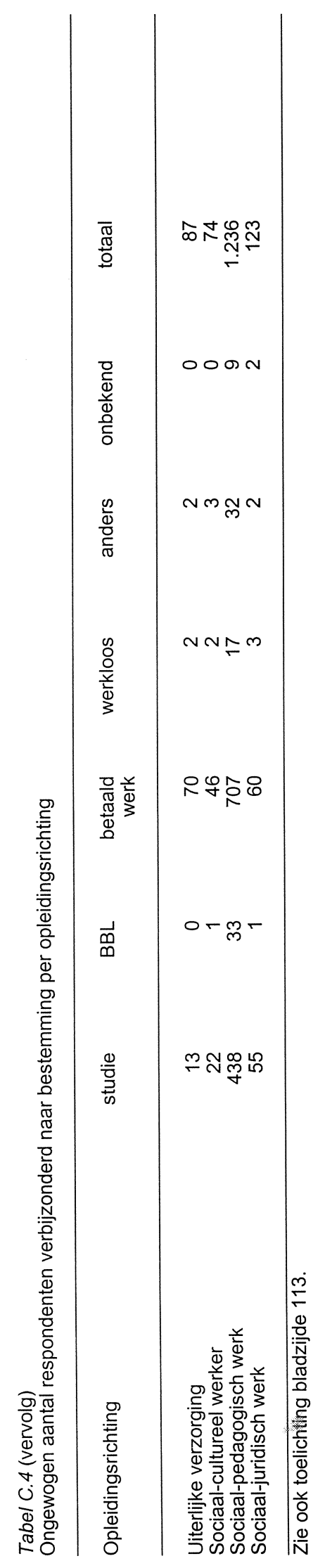




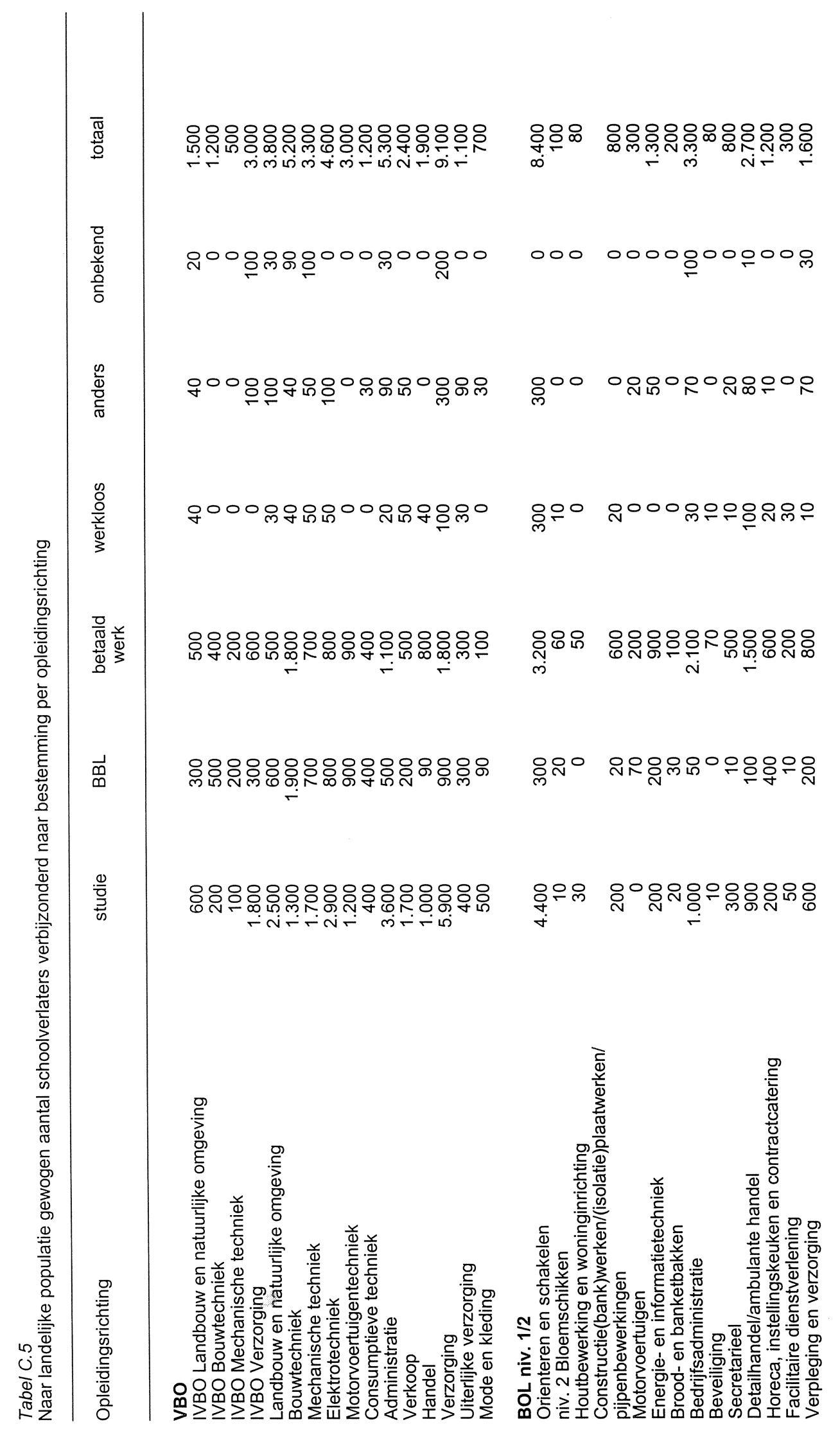




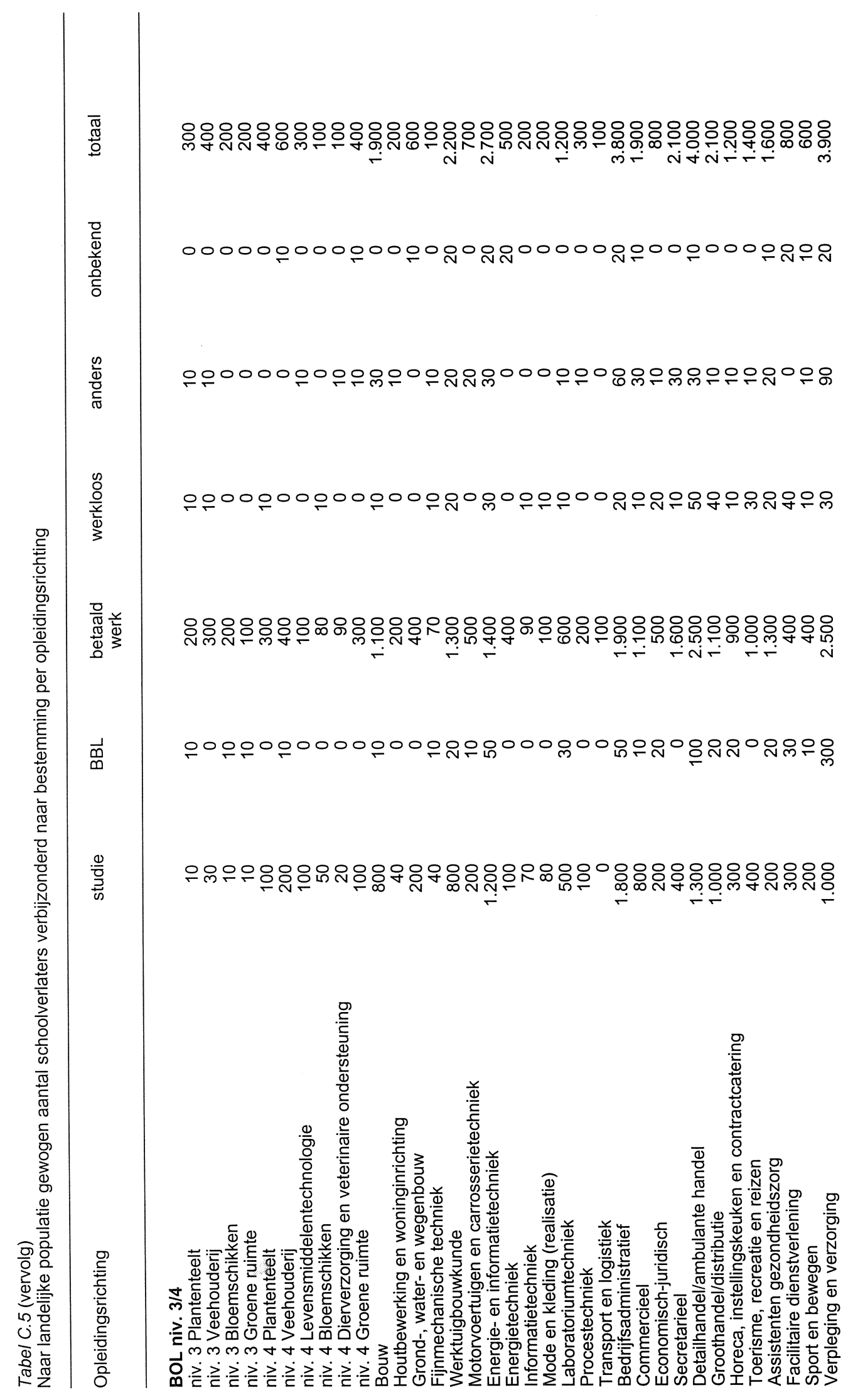




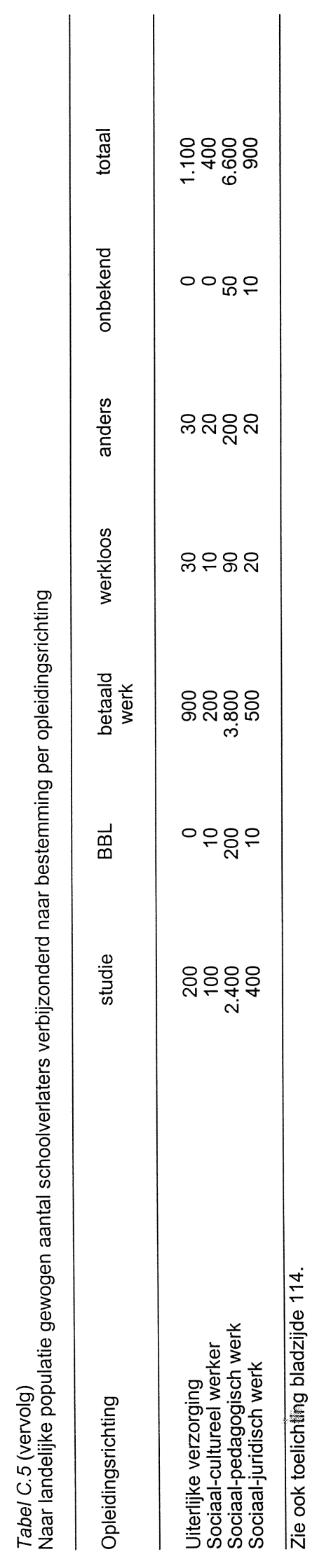


Tabel C.6

Responspercentage per opleidingsrichting

Opleidingsrichting

VBO

IVBO Landbouw en natuurlijke omgeving 49

IVBO Bouwtechniek 48

IVBO Mechanische techniek 40

IVBO Verzorging 50

Landbouw en natuurlijke omgeving 56

Bouwtechniek 43

Mechanische techniek 40

Elektrotechniek 46

Installatietechniek 38

Motorvoertuigentechniek 446

$\begin{array}{ll}\text { Consumptieve techniek } & 41 \\ \text { Administratie } & 50\end{array}$

$\begin{array}{lr}\text { Administratie } & 50 \\ \text { Verkoop } & 42\end{array}$

Handel

Verzorging 53

$\begin{array}{lr}\text { Uiterlijke verzorging } & 44 \\ \text { Mode en kleding } & 43\end{array}$

BOL niv. $1 / 2$

Orienteren en schakelen $\quad 26$

$\begin{array}{ll}\text { Bloemschikken } & 29\end{array}$

$\begin{array}{ll}\text { Houtbewerking en woninginrichting } & 37\end{array}$

Constructie(bank)werken/(isolatie)plaatwerken/pijpenbewerkingen 31

Motorvoertuigen 20

$\begin{array}{ll}\text { Energie- en informatietechniek } & 28 \\ \text { Brood- en banketbakken } & 45\end{array}$

\begin{tabular}{lr} 
Bedrijfsadministratie & 27 \\
\hline
\end{tabular}

$\begin{array}{ll}\text { Beveiliging } & 27\end{array}$

Secretarieel 48

Detailhandel/ambulante handel $\quad 21$

Horeca, instellingskeuken en contractcatering $\quad 33$

$\begin{array}{ll}\text { Facilitaire dienstverlening } & 25 \\ \text { Verpleging en verzorging } & 35\end{array}$

BOL niv. $3 / 4$

niv. 3 Plantenteelt

niv. 3 Veehouderij

niv. 3 Bloemschikken

niv. 3 Groene ruimte

niv. 4 Plantenteelt

niv. 4 Veehouderij

niv. 4 Levensmiddelentechnologie

niv. 4 Bloemschikken

niv. 4 Dierverzorging en veterinaire ondersteuning

niv. 4 Groene ruimte

Bouw

Houtbewerking en woninginrichting

Grond-, water- en wegenbouw

Fijnmechanische techniek

Werktuigbouwkunde

Motorvoertuigen en carrosserietechniek

Energie- en informatietechniek

Energietechniek

Informatietechniek

Mode en kleding (realisatie)

Laboratoriumtechniek

Procestechniek

Transport en logistiek

Bedrijfsadministratief

Commercieel

Economisch-juridisch

Secretarieel

\begin{tabular}{l}
48 \\
3 \\
\hline \\
4 \\
4 \\
4 \\
4 \\
4 \\
4 \\
4 \\
4
\end{tabular}


Tabel C.6

Responspercentage per opleidingsrichting

Opleidingsrichting

Detailhandel/ambulante handel

Groothandel/distributie

31

Horeca, instellingskeuken en contractcatering 37

Toerisme, recreatie en reizen $\quad 45$

Assistenten gezondheidszorg

Facilitaire dienstverlening 43

Sport en bewegen $\quad 45$

Verpleging en verzorging

Uiterlijke verzorging 39

Sociaal-cultureel werker $\quad 42$

Sociaal-pedagogisch werk $\quad 50$

Sociaal-juridisch werk

Zie ook toelichting bladzijde 115 . 
D. Opleidingsindeling 
Overzicht van opleidingen per opleidingssector

MAVO

MAVO

HAVO

HAVO

HAVO-MBO

VHBO

VWO

Atheneum

Gymnasium

IVBO

IVBO Landbouw en natuurlijke omgeving

IVBO Bouwtechniek

IVBO Mechanische techniek

IVBO Consumptieve techniek

IVBO Verkoop

IVBO Verzorging

IVBO Uiterlijke verzorging

IVBO Mode en kleding

IVBO Algemene voorbereiding op maatschappij en beroep (AVMB)

VBO Landbouw

VBO Landbouw en natuurlijke omgeving

VBO Techniek

VBO Bouwtechniek

VBO Mechanische techniek

VBO Elektrotechniek

VBO Installatietechniek

VBO Motorvoertuigentechniek

VBO Consumptieve techniek

VBO Grafische techniek

VBO Economie

VBO Administratie

VBO Verkoop

VBO Handel

VBO Gezondheidszorg

VBO Verzorging

VBO Uiterlijke verzorging

VBO Mode en kleding

BOL niveau 1/2 oriënteren en schakelen

Oriënteren en schakelen

BOL niveau 1/2 Landbouw

BOL BB Plantenteelt

BOL BB Veehouderij

BOL BB Levensmiddelentechnologie

BOL BB Bloemschikken 
BOL BB Dierverzorging en veterinaire ondersteuning

BOL BB Groene ruimte

BOL niveau 1/2 Techniek

BOL BB Bouw

BOL BB Houtbewerking en woninginrichting

BOL BB Constructie(bank)werken/(isolatie)plaatwerken/pijpenb

BOL BB Motorvoertuigen

BOL BB Energie- en informatietechniek

BOL BB Installatie-, service- en onderhoudstechniek

BOL BB Mode en kleding (realisatie)

BOL BB Procestechniek

BOL BB Scheepvaart

BOL BB Brood- en banketbakken

$B O L$ niveau $1 / 2$ Economie

$\mathrm{BOL} A B$ Beveiliging

BOL AB Secretarieel

BOL BB Bedrijfsadministratie

BOL BB Beveiliging

BOL BB Secretarieel

BOL BB Detailhandel/ambulante handel

$\mathrm{BOL}$ BB Horeca, instellingskeuken en contractcatering

BOL niveau 1/2 Gezondheidszorg

BOL BB Facilitaire dienstverlening

$B O L B B$ Verpleging en verzorging

BOL BB Uiterlijke verzorging

$B O L$ niveau 3/4 Landbouw

BOL ZB Plantenteelt

BOL ZB Veehouderij

BOL ZB Levensmiddelentechnologie

BOL ZB Bloemschikken

BOL ZB Dierverzorging en veterinaire ondersteuning

BOL ZB Paardenhouderij en paardensport

BOL ZB Groene ruimte

BOL KF Plantenteelt

BOL KF Veehouderij

BOL KF Levensmiddelentechnologie

BOL KF Bloemschikken

BOL KF Dierverzorging en veterinaire ondersteuning

BOL KF Paardenhouderij en paardensport

BOL KF Groene ruimte

BOL KF Milieutoezicht

BOL niveau 3/4 Techniek

$\mathrm{BOL}$ ZB Beheer, ontwerp en management (installatietechniek)

BOL ZB Laboratoriumtechniek

BOL MKF Techniek

BOL MKF Bouw

BOL MKF Houtbewerking en woninginrichting

BOL MKF Grond-, water- en wegenbouw

BOL MKF Fijnmechanische techniek

BOL MKF Operationele techniek

BOL MKF Werktuigbouwkunde 
BOL MKF Motorvoertuigen en carrosserietechniek

BOL MKF Energie- en informatietechniek

BOL MKF Energietechniek

BOL MKF Informatietechniek

BOL MKF Mode en kleding (realisatie)

BOL MKF Laboratoriumtechniek

BOL MKF Milieutechniek

BOL MKF Procestechniek

BOL MKF Scheepvaart

BOL MKF Transport en logistiek

BOL niveau 3/4 Economie

BOL ZB Bedrijfsadministratief

BOL ZB Secretarieel

BOL MKF Economie

BOL MKF Bedrijfsadministratief

BOL MKF Commercieel

BOL MKF Economisch-juridisch

BOL MKF Logistiek

BOL MKF Secretarieel

BOL MKF Detailhandel/ambulante handel

BOL MKF Groothandel/distributie

BOL MKF Textielhandel

BOL MKF Horeca, instellingskeuken en contractcatering

BOL MKF Toerisme, recreatie en reizen

BOL niveau 3/4 Gezondheidszorg

$B O L$ ZB Verpleging en verzorging

BOL ZB Uiterlijke verzorging

BOL MKF Assistenten gezondheidszorg

BOL MKF Facilitaire dienstverlening

BOL MKF Sport en bewegen

BOL MKF Verpleging en verzorging

BOL niveau 3/4 Gedrag en maatschappij

BOL MKF Sociaal-cultureel werker

BOL MKF Sociaal-pedagogisch werk

BOL MKF Sociaal-juridisch werk

HBO Landbouw

HBO Tropische landbouw

HBO Tuinbouw

HBO Plantenteelt

HBO Veehouderij

HBO Diermanagement

HBO Agrarische bedrijfskunde

$\mathrm{HBO}$ Internationale agrarische handel

HBO Agrologistiek

HBO Agrarische accountancy

HBO Milieukunde (agrarisch)

HBO Tuin- en landschapsinrichting

$\mathrm{HBO}$ Bos- en natuurbeheer

HBO Land-, water- en milieubeheer

HBO Milieutechnologie (agrarische)

HBO Laboratoriumtechniek

HBO Levensmiddelentechnologie 
HBO Agroproductkunde

HBO Docent plantenteelt en verwerking (2e gr.)

HBO Docent dier/veehouderij (2e gr.)

HBO Docent levensmiddelentechnologie (2e gr.)

HBO Docent agrarische economie (2e gr.)

HBO Docent agrarische techniek (2e gr.)

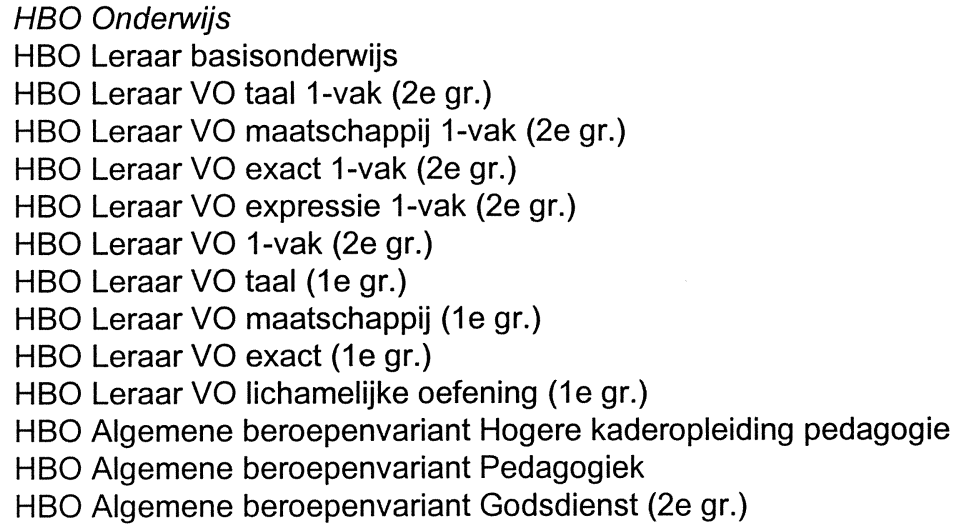


HBO Chemische laboratoriumopleiding

HBO Medische laboratoriumopleiding

HBO Laboratoriuminformatica en automatisering

HBO Duaal Milieukunde

HBO Economie

HBO Kort Facilitaire dienstverlening

HBO Kort Hoger toeristisch en recreatief onderwijs

HBO Kort Bedrijfskundige informatica

HBO Accountancy

HBO Bedrijfseconomie

HBO Fiscale economie

HBO Hoger onderwijs voor de financiele sector

HBO Bedrijfskundige informatica

HBO Bestuurskunde/overheidsmanagement

HBO Management, economie en recht

HBO Bedrijfswiskunde

HBO Commerciele economie

HBO Logistiek en economie

HBO Economisch-linguistische opleiding

HBO Small business en retail management

$\mathrm{HBO}$ Boekhandel en uitgeverij

HBO Communicatie

HBO Communicatiesystemen

$\mathrm{HBO}$ Journalistiek en voorlichting

HBO Opleiding tolk-vertaler

HBO Orientaalse talen en communicatie

$\mathrm{HBO}$ Informatiedienstverlening en -management

HBO Facilitaire dienstverlening

HBO Hoger hotelonderwijs

HBO Hoger toeristisch en recreatief onderwijs

HBO Vrijetijdskunde

HBO Duaal Accountancy

HBO Gezondheidszorg

HBO Opleiding tot verpleegkundige

HBO Opleiding verpleegkundige maatschappelijke gezondheidszo

HBO Opleiding van kader in de gezondheidszorg

$\mathrm{HBO}$ Bewegingstechnologie

HBO Medisch beeldvormende/radiotherapeutische technieken

HBO Fysiotherapie

HBO Ergotherapie

HBO Logopedie

HBO Optometrie

HBO Voeding en dietetiek

HBO Antroposofische gezondheidszorg

HBO Opleiding mondhygienist

HBO Opleiding tot orthoptist

HBO Bewegingsagogie/psychomotorische therapie

HBO Huidtherapie

HBO Opleiding oefentherapeut-Cesar

HBO Opleiding oefentherapeut-Mensendieck

HBO Opleiding podotherapie

HBO Lerarenopleiding verpleegkunde (2e gr.) 
HBO Gedrag en maatschappij

HBO Creatieve therapie

HBO Culturele en maatschappelijke vorming

HBO Expressie door woord en gebaar

HBO Maatschappelijk werk en dienstverlening

HBO Personeel en arbeid

HBO Sociaal-juridische dienstverlening

HBO Sociaal pedagogische hulpverlening

HBO Kunst en cultuur

$\mathrm{HBO}$ Algemene industriele vormgeving

HBO Architectonische vormgeving

HBO Film- en t.v.-vormgeving

HBO Fotografische vormgeving

HBO Keramische vormgeving

HBO Modevormgeving

HBO Monumentale vormgeving

HBO Museologie

HBO Plastische vormgeving

HBO Publiciteits- c.q. grafische vormgeving

HBO Schilderkundige vormgev. en vormgev. op gebied vd grafie

HBO Textiele vormgeving

HBO Vormgeving in metalen en kunststoffen

HBO Beeldende kunst en vormgeving - vrij

HBO Compositie of compositie/elektronische muziek

HBO Directie koor, orkest of harmonie en fanfare

HBO Docerend musicus

HBO Muziek-dramatische opleiding

HBO Muziekregistratie

HBO Theorie der muziek

HBO Uitvoerend musicus

HBO Opleiding praktijkdiploma directie harmonie en fanfare

HBO Opleiding praktijkdiploma koordirectie

HBO Opleiding praktijkdiploma orkest- en ensembleleiding

HBO Uitvoerende beoefening van de kleinkunst

HBO Uitvoerende beoefening van de mime

HBO Uitvoerende beoefening van het drama

HBO Uitvoerende beoefening van de dans

HBO Leraar handvaardigheid (1e gr.)

HBO Leraar textiele werkvormen (1e gr.)

HBO Leraar tekenen (1e gr.)

HBO Staatsdiploma handvaardigheid $B$

HBO Getuigschrift muziekonderwijs A algemene muzikale vormin

HBO Getuigschrift muziekonderwijs B schoolmuziek

HBO Docent dans

HBO Docent drama

HBO Kunst en techniek

HBO Kunst/mediamanagement

WO Landbouw

WO Bos- en natuurbeheer

WO Landinrichtingswetenschappen

WO Tropisch landgebruik

WO Plantenteeltwetenschappen

WO Tuinbouwplantenteelt

WO Plantenveredeling en gewasbescherming 
WO Zootechniek

WO Bioprocestechnologie

WO Levensmiddelentechnologie

WO Landbouwtechniek

WO Economie van landbouw en milieu

WO Voeding en gezondheid

WO Rurale ontwikkelingsstudies

WO Huishoud- en consumentenwetenschappen

WO Agrosysteemkunde

WO Bodem, water en atmosfeer

WO Biologie

WO Milieuhygiene

WO Moleculaire wetenschappen

WO Techniek

WO Technische aardwetenschappen

WO Scheikundige technologie en bioprocestechnologie

WO Microbiologie en enzymologie

WO Technische natuurkunde

WO Bedrijfskundige aspecten

WO Technische wiskunde

WO Toegepaste analyse

WO Bedrijfsinformatietechnologie

WO Informatietechniek

WO Technische informatica

WO Elektrotechniek

WO Vermogenselektronica en elektrische machines

WO Bouwkunde

WO Civiele techniek

WO Civiele technologie en management

WO Geodesie

WO Installatietechniek

WO Industrieel ontwerpen

WO Luchtvaart- en ruimtevaarttechniek

WO Maritieme techniek

WO Materiaalkunde

WO Werktuigbouwkunde

WO Ontwerp en produktie

WO Werktuigkundige medische technologie

WO Technische bedrijfskunde

WO Technische bestuurskunde

WO Techniek en maatschappij

WO Economie

WO Economie (opleiding)

WO Algemene economie

WO Alg. economie Ruimtelijke economie

WO Bedrijfseconomie

WO Bedrijfseconomie Accountancy

WO Bedrijfseconomie Ruimtelijke bedrijfseconomie

WO Internationaal management

WO Economie vrij doctoraal

WO Beleidsgerichte economie

WO International Economic Studies (IES)

WO Economische en historische studies

WO Fiscale economie 
WO Internationale economie en economische geografie

WO Recht en economie in bedrijf en maatschappij

WO Sociale en institutionele economie

WO Japankunde

WO Actuariele wetenschappen

WO Bedrijfseconometrie

WO Econometrie

WO Econometrie Vrij doctoraal

WO Operationele research en management

WO Bestuurlijke informatiekunde

WO Bedrijfskunde

WO Bedrijfskunde (opleiding) (ook OU)

WO Internationale bedrijfskunde

WO Bedrijfswetenschappen

WO Bedrijfskunde van de financiele sector

WO Gezondheidszorg

WO Diergeneeskunde

WO Geneeskunde

WO Tandheelkunde

WO Beleid en management gezondheidszorg

WO Bewegingswetenschappen

WO Biomedische wetenschappen

WO Gezondheidswetenschappen

WO Beleid en beheer van de gezondheidszorg (BB)

WO Bewegingswetenschappen (BW)

WO Biologische gezondheidkunde (BGK)

WO Geestelijke gezondheidkunde (GGK)

WO Gezondheidsvoorlichting (GVO)

WO Verplegingswetenschap (VW)

WO Theorie van de gezondheidswetenschappen

WO Medische biologie

WO Medische informatiekunde

WO Milieugezondheidkunde

WO Gedrag en maatschappij

WO Cognitiewetenschap

WO Psychologie (ook OU)

WO Sociaal-wetenschappelijke informatica

WO Technische cognitiewetenschap

WO Pedagogische wetenschappen

WO Onderwijskunde

WO Communicatiewetenschap

WO Toegepaste communicatiewetenschap

WO Algemene sociale wetenschappen

WO Culturele antropologie/Soc niet-Westerse samenlevingen

WO Ontwikkelingsstudies

WO Sociaal-culturele wetenschappen

WO Sociologie

WO Vrijetijdswetenschappen

WO Arbeid en sociale zekerheid

WO Personeelwetenschappen

WO Recht, bestuur en management

WO Beleids- en organisatiewetenschappen

WO Beleidsgerichte milieukunde

WO Bestuurs- en organisatiewetenschap 
WO Bestuurskunde (ook OU)

WO Politicologie (RUL, UvA, KUN)

WO Politicologie en bestuurskunde (VU)

WO Planologie

WO Sociale geografie

WO Technische planologie

WO Demografie

WO Internationaal-juridische opleiding

WO Juridische bestuurswetenschappelijke opleiding

WO Juridisch-politiekwetenschappelijke opleiding

WO Taal en cultuur

WO Griekse en Latijnse talen en culturen

WO Nederlandse taal- en letterkunde

WO Duitse taal- en letterkunde

WO Engelse taal- en letterkunde

WO Franse taal- en letterkunde

WO Friese taal- en letterkunde

WO Italiaanse taal- en letterkunde

WO Keltische talen en cultuur

WO Portugese taal- en letterkunde

WO Roemeense taal- en letterkunde

WO Romaanse talen en culturen

WO Scandinavische talen en hun letterkunde

WO Spaanse taal- en letterkunde

WO Talen en culturen van Latijns Amerika

WO Afrikaanse taalkunde

WO Arabische, Nieuwperzische en Turkse talen en culturen

WO Chinese talen en culturen

WO Egyptische taal en cultuur

WO Finoegrische talen en letterkunde

WO Indische en Iraanse talen en culturen

WO Talen en culturen van Zuidoost-Azie en Oceanie

WO Japanse taal en cultuur

WO Semitische talen en culturen

WO Slavische talen en hun letterkunde

WO Talen en culturen van Indiaans Amerika

WO Alfa-informatica

WO Algemene letteren

WO Algemene literatuurwetenschap

WO Algemene taalwetenschap

WO Fonetiek

WO Letteren

WO Spraak- en taalpathologie

WO Taal, spraak en informatica

WO Vertaalwetenschap

WO Toegepaste taalwetenschap

WO Vergelijkende taalwetenschap

WO Afrikanistiek

WO Amerikanistiek

WO Duitslandstudies

WO Dutch studies

WO Europese studies

WO Mediterrane studies

WO Oost-europese studies

WO Ruslandkunde 
WO Bedrijfscommunicatie letteren

WO Boek- en informatiewetenschap

WO Communicatiekunde

WO Taal, informatie en communicatie

WO Beleid en bestuur internationale organisaties

WO Culturele studies

WO Cultuur- en wetenschapsstudies

WO Film- en opvoeringskunsten

WO Film- en televisiewetenschappen

WO Kunst- en cultuurwetenschappen

WO Muziekwetenschap

WO Taal- en cultuurstudies

WO Theaterwetenschap (UvA)

WO Vergelijkende kunstwetenschap: woord en beeld

WO Algemene opleiding godgeleerdheid

WO Godgeleerdheid

WO Godsdienstwetenschappen

WO Islamologie/Islamkunde

WO Levensbeschouwingen

WO Religie en levensbeschouwing

WO Religiestudies

WO Archeologie (opleiding)

WO Mediterrane archeologie

WO Europese archeologie

WO Geschiedenis

WO Kunstgeschiedenis en archeologie

WO Maatschappijgeschiedenis

WO Medievistiek

WO Oudheidkunde

WO Wijsbegeerte

WO Wijsbegeerte van een bepaald wetenschapsgebied

WO Recht en openbare orde

WO Nederlands recht

WO Nederland recht Vrij doctoraal

WO Nederlands recht, internationale/Europees rechtelijke opl

WO Notariele opleiding

WO Fiscaal-juridische opleiding

WO Internationaal recht

WO Juridische bestuurswetenschappelijke opleiding

WO Natuurwetenschappen

WO Bedrijfs- en industriele statistiek

WO Statistiek

WO Wiskunde

WO Bedrijfsgerichte informatica

WO Bedrijfsinformatica

WO Bedrijfsinformatiesystemen

WO Bedrijfswiskunde en informatica

WO Cognitieve kunstmatige intelligentie

WO Informatica

WO Kennistechnologie

WO Kunstmatige intelligentie

WO Technische informatica

WO Technisch gerichte informatica

WO Natuurkunde 
WO Sterrrenkunde

WO Geochemie

WO Geofysica

WO Geologie

WO Meteorologie en fysische oceanografie

WO Fysische geografie

WO Scheikunde

WO Biofarmaceutische wetenschappen

WO Farmacie

WO Farmacochemie

WO Fundamentele biomedische wetenschappen

WO Milieubiologie

WO Milieukunde

WO Natuurwetenschappelijke milieukunde

WO Milieuwetenschappen/scheikunde

WO Milieuwetenschappen/aardwetenschappen

WO Milieuwetenschappen/biologie

WO Milieuwetenschappen/natuurkunde

WO Natuurwetenschappen en bedrijf \& bestuur

WO Wetenschapsdynamica

WO Biologie

WO Medische biologie 
